\title{
Republic of Latvia: Request for Stand-By Arrangement-Staff Report; Staff Supplement; Press Release on the Executive Board Discussion; and Statement by the Executive Director for the Republic of Latvia
}

In the context of the request for a Stand-By Arrangement, the following documents have been released and are included in this package:

- $\quad$ The staff report for the Request for Stand-By Arrangement, prepared by a staff team of the IMF, following discussions that ended on December 18, 2008, with the officials of the Republic of Latvia on economic developments and policies. Based on information available at the time of these discussions, the staff report was completed on December 19, 2008. The views expressed in the staff report are those of the staff team and do not necessarily reflect the views of the Executive Board of the IMF.

- $\quad$ A staff supplement of December 19, 2008, on the assessment of the risks to the Fund and the Fund's liquidity position.

- $\quad$ A Press Release summarizing the views of the Executive Board as expressed during its December 23, 2008 discussion of the staff report that completed the review.

- $\quad$ A statement by the Executive Director for the Republic of Latvia.

The documents listed below have been or will be separately released.

Letter of Intent sent to the IMF by the authorities of the Republic of Latvia* Technical Memorandum of Understanding*

*Also included in Staff Report

The policy of publication of staff reports and other documents allows for the deletion of market-sensitive information.

Copies of this report are available to the public from

International Monetary Fund • Publication Services

$70019^{\text {th }}$ Street, N.W. • Washington, D.C. 20431

Telephone: (202) 623-7430 • Telefax: (202) 623-7201

E-mail: publications@imf.org • Internet: http://www.imf.org

Price: $\$ 18.00$ a copy

\section{International Monetary Fund Washington, D.C.}





\title{
INTERNATIONAL MONETARY FUND
}

\author{
REPUBLIC OF LATVIA
}

\section{Request for Stand-By Arrangement}

\author{
Prepared by the European Department \\ (In Consultation with Other Departments)
}

Approved by Anne-Marie Gulde-Wolf and Tessa van der Willigen

December 19, 2008

- Stand-By Arrangement. In the attached letter, the Latvian authorities request a 27-month Stand-By Arrangement under the exceptional access policy, in the amount equivalent to SDR 1.521626 billion (1200.02 percent of quota, approximately $€ 1.7$ billion, or US $\$ 2.35$ billion). The request is being considered under the Emergency Financing Mechanism (EFM). An initial purchase of SDR 0.54 billion becomes available on Board approval. In the letter, the authorities outline the rationale for adopting the economic program for which they seek Fund financial support and describe the measures they intend to take to meet their policy objectives.

- The program's main objectives are to arrest the immediate liquidity crisis and then to ensure long-term external stability, while maintaining the exchange rate peg. The program includes measures to stabilize the financial sector and restore depositor confidence. It also includes substantial fiscal policy tightening to reduce financing needs and foster real depreciation. Structural reforms and incomes policies will be developed to improve competitiveness and facilitate external adjustment.

- Discussions. During November 17-23 and December 5-18, 2008 the staff team met with Prime Minister Godmanis, Minister of Finance Slakteris, Governor Rimšēvičs, Head of the Financial and Capital Markets Commission Krūmane, senior officials in these institutions, opposition party leaders, social partners, and representatives of financial institutions.

- Staff. The staff team comprised Christoph Rosenberg (head), Gavin Gray, Mark Griffiths, Athanasios Vamvakidis (EUR); Francois Michel (FAD); John Austin, Thomas Laryea and Yan Liu (LEG); Michaela Erbenova and David Parker (MCM); and Chris Marsh (SPR). The mission cooperated closely with staff of the European Commission, ECB, World Bank, EBRD, Swedish Ministry of Finance and Riksbank, and Nordic country governments. Jens Henriksson, Executive Director for the Nordic and Baltic countries, participated in some of the meetings.

- Publication. The Latvian authorities authorize publication of the staff report, the Letter of Intent and its attachments. 


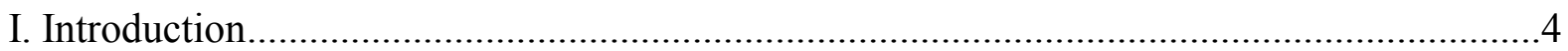

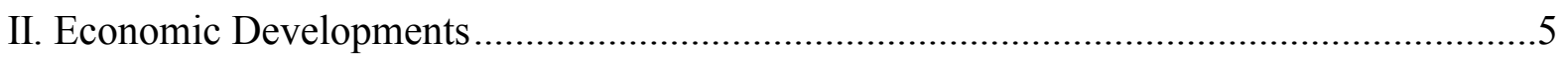

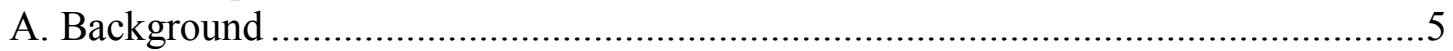

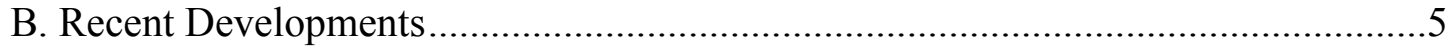

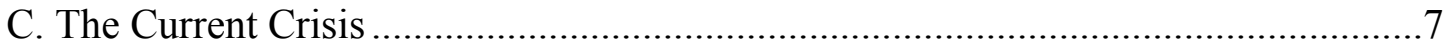

III. The Authorities' Program................................................................................................. 9

A. Monetary and Exchange Rate Policy ......................................................... 9

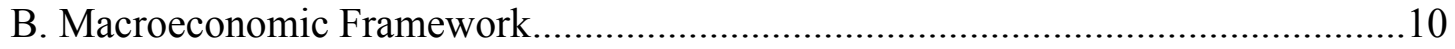

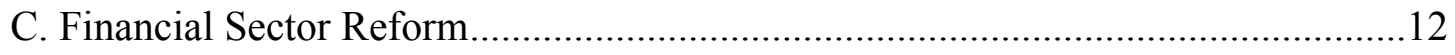

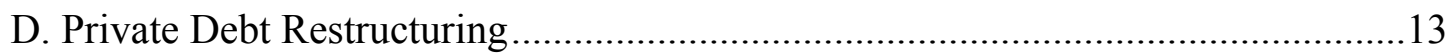

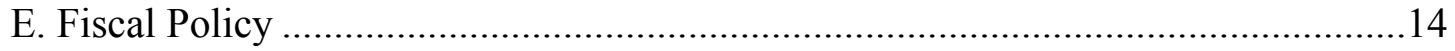

F. Structural Reform and Incomes Policy ......................................................... 18

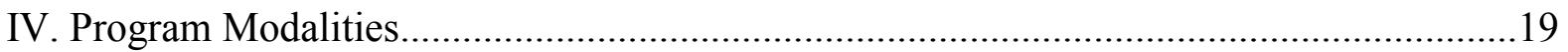

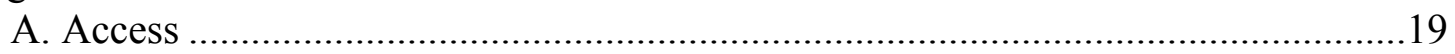

B. Capacity to Repay the Fund and Risks to the Program .......................................20

C. Program Monitoring and Conditionality ........................................................22

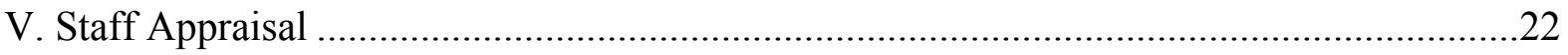

\section{Text Boxes}

1. Alternative Exchange Rate Options.............................................................26

2. Cross-Country Evidence on Real Exchange Rate Adjustments.................................28

3. Latvia's Fiscal Adjustment in Historical Perspective ............................................29

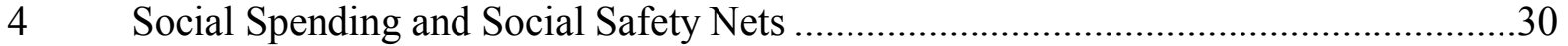

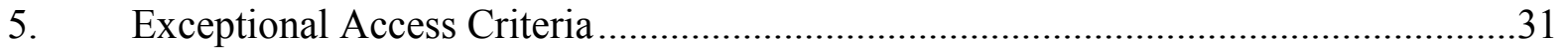

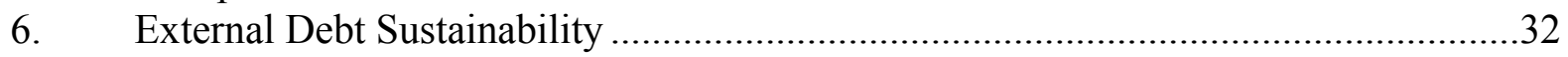

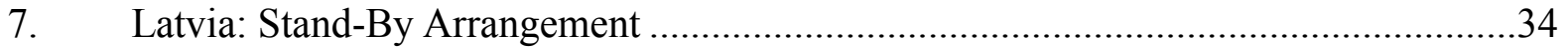

\section{Figures}

1. Exchange Rates, Interbank Interest Rates, and Intervention...................................35

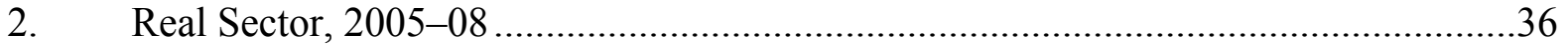

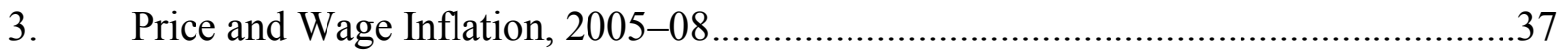

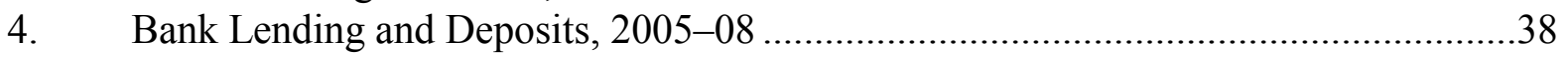

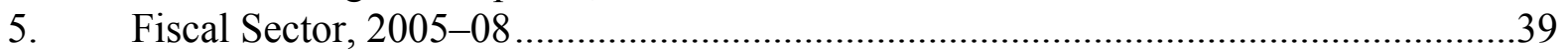

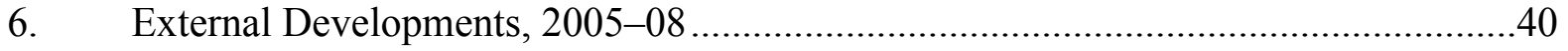

7. Banking Sector Solvency and Liquidity, 2005-08 ............................................41

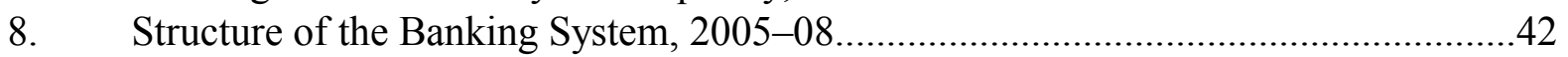

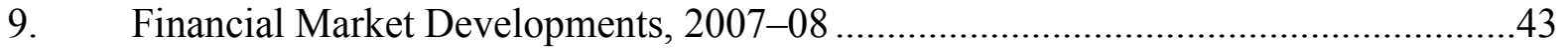

10. External Debt Sustainability: Bound Tests …......................................................44 


\section{Tables}

1. Selected Economic Indicators, 2004-10 .............................................................45

2. General Government Operations, 2006-10 ...........................................................46

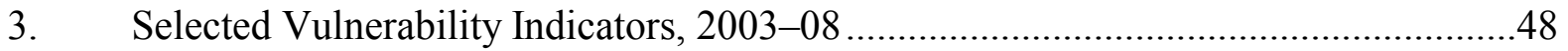

4. Medium-Term Balance of Payments, 2005-13 ....................................................49

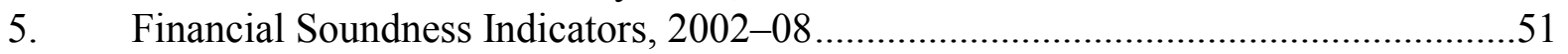

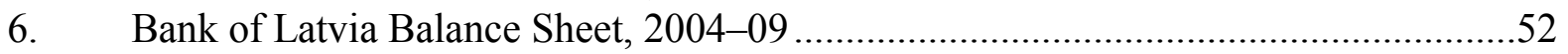

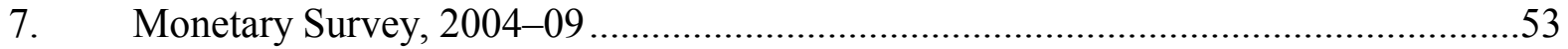

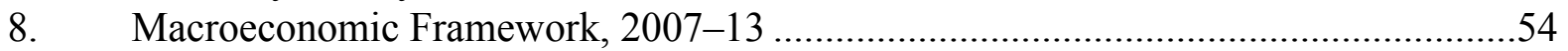

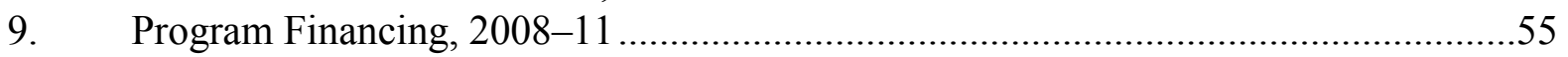

10. Schedule of Reviews and Purchases ....................................................................56

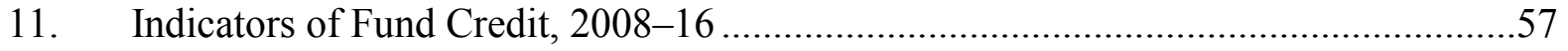

12. Public Sector Debt Sustainability Framework, 2003-13 .........................................58

13. External Debt Sustainability Framework, 2003-13 .............................................59

Attachments

Attachment I. Latvia: Letter of Intent ..................................................................6

Attachment II. Latvia: Technical Memorandum of Understanding (TMU) .........................73 


\section{INTRODUCTION}

1. Years of unsustainably high growth and large current account deficits have coalesced into a financial and balance of payments crisis. Since end-August, private sector deposits have fallen by 10 percent, led by a run on Parex Bank (the second largest bank, and largest domestically owned) which encountered severe liquidity problems after it lost more than a quarter of its deposits. Attempts by the government to negotiate a partial take over of this bank, while allowing the main shareholders to retain significant influence, failed to restore confidence. From end-August to end-November, official reserves fell by almost 20 percent to $€ 3.4$ billion, one third of short-term external debt and just over 100 percent of base money (from 127 percent in September), as the central bank sold foreign currency to defend the peg. Despite this substantial intervention, since early October the exchange rate has remained at its upper (depreciated) band, while interbank spreads have spiked (Figure 1). Concerns over the financial system and external debt sustainability increased, and the exchange rate peg came under threat.

2. The Latvian authorities are launching a decisive economic reform program and are seeking substantial international financial assistance to quell this crisis. The global liquidity crisis has prevented the government from accessing outside private capital markets and obtaining the foreign currency needed to bolster the banking system and to re-establish confidence. With international reserves falling precipitously and reserves barely covering base money, the authorities are now seeking Fund assistance under the emergency financing procedures. The authorities are also requesting support from the European Union's balance of payments facility (consistent with commitments under Article 119 of the European Community treaty), partner countries and other international organizations.

3. The proposed Fund-supported program is part of a coordinated international effort. The European Commission has participated fully in the Fund mission, along with representatives from the ECB (in line with Latvia's ERM2 membership), Sweden and other Nordic countries. Financial assistance and expertise from the World Bank and EBRD are other key components of the international response.

\section{The program is centered on maintaining Latvia's exchange rate peg through} strong domestic policies and substantial international financial assistance. Key elements include: (i) immediate measures to stem the loss of bank deposits and international reserves; (ii) steps to restore confidence in the banking system in the medium-term; (iii) fiscal measures to limit the substantial widening in the budget deficit, and prepare for early fulfillment of the Maastricht criteria; and (iv) incomes policies and structural reforms that will rebuild competitiveness under the fixed exchange rate regime. With substantial international support, these policies should allow the economy eventually to emerge from a period of slow growth, with fewer strains on corporate and household balance sheets. 


\section{ECONOMIC DEVELOPMENTS}

\section{A. Background}

5. Since 2000, Latvia's economy has grown extremely rapidly. From 2000 to 2007, GDP expanded at an average annual rate of 9 percent, the fastest in the EU. Per capita income rose from 37 percent to just under 60 percent of the EU27 average. Rapid growth initially reflected utilization of excess capacity (after the Russian crisis) and productivity gains from successful reforms. Growth further accelerated after EU accession in 2004, driven by privatesector capital inflows and EU funds, although sizable outward migration dampened potential growth.

\section{But by mid-2006 the economy was overheating:}

- $\quad$ Credit grew at an annualized rate of more than 50 percent even though the stock of credit (70 percent of GDP at end-2005) had risen to close to the EU average. Real estate prices jumped more than 60 percent in both 2005 and 2006.

- Domestic demand grew excessively, especially private consumption and real estate investment (Figure 2), so that the current account deficit peaked in late 2006 at more than 25 percent of GDP.

- Wage and price inflation accelerated in early 2007, with core inflation rising to almost 10 percent year on year by mid-2007 (Figure 3). The CPI-based real effective exchange rate appreciated by 15 percent from EU accession to end-2007. Substantial wage increases and low productivity growth meant the ULC-based real exchange rate appreciated even more rapidly.

7. Procyclical fiscal policy contributed to the boom. Real expenditure grew by 80 percent between 2003 and 2007 as the authorities spent cyclically strong tax revenues and began receiving substantial inflows of net EU grants. Staff estimates a cumulative fiscal stimulus of more than 6 percent of GDP through end-2007, while output exceeded potential by 9 percent.

\section{B. Recent Developments}

8. The economy is now slowing rapidly (Table 1). GDP started to level off from the fourth quarter of 2007, and this year is projected to fall by 2 percent. The main cause is a slowdown in lending that started in early 2007, driven by concerns among foreign banks about their overexposure to the Baltics (Figure 4). As a consequence, consumption and investment fell. While the overheated non-tradables sector needed to slow down, manufacturing output also dropped sharply due to weaker export demand, and the lagged effects of the past deterioration in competitiveness. Wage growth has started to decelerate and employment to decline. 
9. Tax revenues have slowed with economic activity, putting this year's budget targets out of reach (Figure 5, Table 2). The government's original objective of a 1 percent surplus was abandoned this summer in favor of budget balance, but even this revised target will not be attained following weak end-year tax revenues, particularly VAT and other revenues linked to domestic demand. Despite attempts to cut appropriations at the end of the year, the deficit is expected to increase to around 3 percent of GDP.

10. The current account deficit is declining quickly, narrowing by more than 10 percentage points in the last year, to 13 percent of GDP in the third quarter of 2008 (Figure 6). As the economy slows, the contraction in the current account deficit has been driven by: (i) a rise in the trade balance of 7.8 percentage points, due to falling imports; and (ii) an increase in the income balance of 1.2 percentage points - due to falling profits and reduced earnings of direct investment by foreign investors.

\section{Despite the current account adjustment, external vulnerabilities remain} substantial (Tables 3 and 4):

- Gross external debt has risen above 130 percent of GDP, the highest among EU new member states.

- External debt with original maturity below one year (including non-resident deposits at call) exceeds 50 percent of GDP. An additional 12 percent of GDP in medium- and long-term external liabilities matures in the next year. Latvia is thus very exposed to the risk of a sudden capital stop.

- Solvency concerns relate primarily to the private sector, which has net external debt of 70 percent of GDP. The public sector is currently a net external creditor, though there is a risk that it will have to assume some private sector liabilities.

- Banks' reported short-term liquid external assets are substantial (45 percent of GDP) and provide some buffer against external outflows. However, the market value of these assets and the ability to realize these quickly in the current international financial environment has come into question.

12. Financial-sector risks accumulated during the boom are materializing rapidly, calling into question the value of bank assets (Table 5). Two-thirds of bank loans are backed by real estate. Since most of these mortgages were issued at the peak of the real estate boom (since when real estate prices have fallen by a third), many of these will now have negative equity. The proportion of overdue loans has picked up; many of these will probably turn non-performing (Figure 7).

13. The banking system's reliance on foreign funding - and the different financing models for domestic versus foreign owned-banks - creates additional complexities (Figures 8): 
- $\quad$ Almost 60 percent of the banking system is owned by banks from Sweden and other Nordic countries. Loans from their parent institutions are these banks' main source of financing. Though parent bank share prices have come under severe pressure, these credit lines have been maintained, and 80 percent of these loans have maturity greater than one year. The introduction of financial support schemes by the home governments of these banks has boosted confidence and helped stabilize their deposits in Latvia. However, foreign bank ownership in Latvia is much lower than in Estonia and Lithuania (97 and 85 percent foreign bank shares).

- The remaining banks are mainly domestically owned (though with a few small banks owned by investors from CIS countries). These banks rely on more fragile forms of foreign financing, mainly short-term syndicated loans and non-resident deposits, which now face considerable redemption pressures given worsened global liquidity conditions. On the surface, reported liquidity and capital adequacy ratios suggest that these banks should be able to withstand a gradual deterioration of loan quality or a mild decline in deposits. However, solvency indicators for all banks were (somewhat artificially) boosted in October as banks reclassified parts of their securities portfolio as "held to maturity" in line with a new IFRS regulation, which allowed them to revalue their assets.

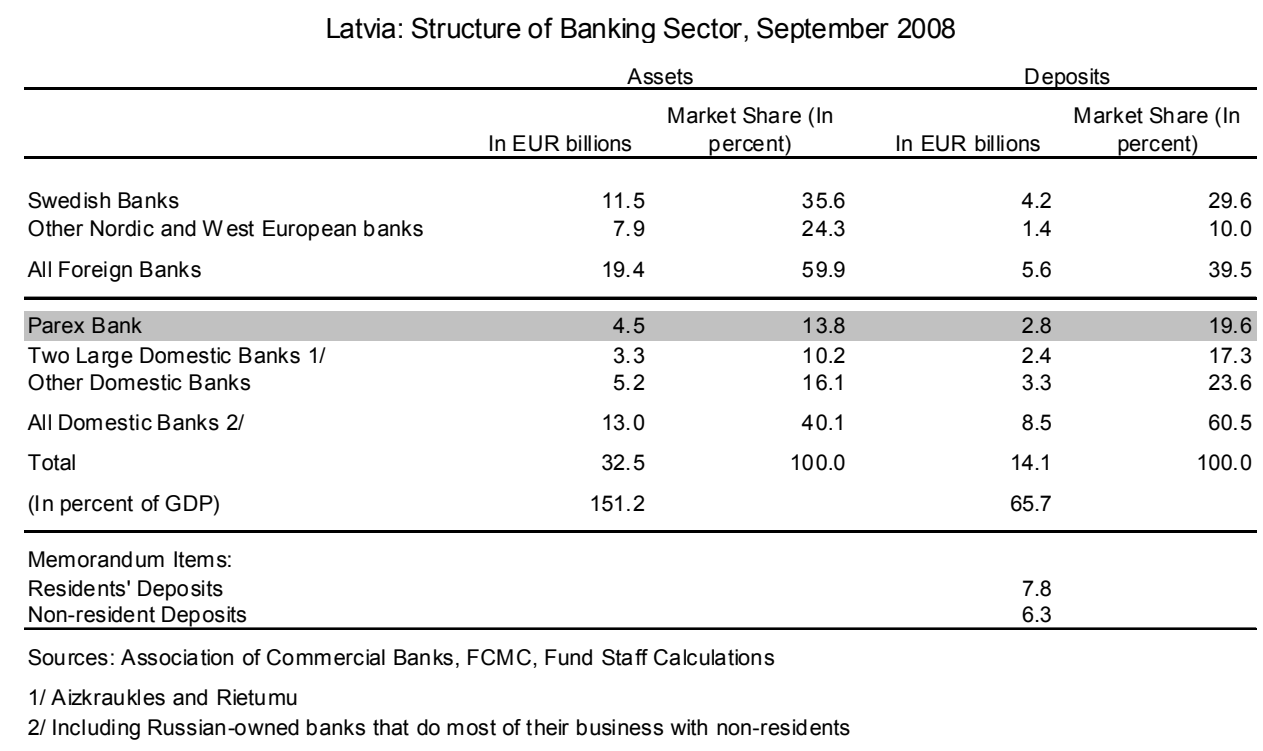

\section{The Current Crisis}

\section{The current international financial market turmoil has brought these}

vulnerabilities to a head. Markets have grown increasingly concerned over the sustainability of the peg, and the likelihood that contingent financial sector liabilities will have to be absorbed by the government. All three ratings agencies have recently downgraded Latvia, with Fitch and S\&P currently assigning it their lowest investment grade ratings, both with 
negative outlook. Latvia's Eurobond spread has increased to around 600 basis points, while its CDS spread has flirted with the 1,000 basis point level (Figure 9). Liquidity demands from non-resident depositors have aggravated these developments.

15. The banking system faces growing liquidity strains as deposit growth falters, which spill over into balance of payments problems (Tables 6 and 7):

- From end-August to end-November, system-wide deposits fell by 10 percent, excluding valuation effects (the appreciation of the dollar artificially increases foreign currency deposits when measured in Lats). Non-resident deposits (almost half total deposits, and overwhelmingly in Latvian-owned banks) have fallen the most (13 percent since end-August). Parex Bank has faced the greatest problems, losing one quarter of its deposits since end-August.

- The BoL has increased liquidity to meet these deposit withdrawals. Since endAugust the BoL has provided LVL 555m (€780 million, 31ㄹㄹ percent of GDP) in additional banking system liquidity. Out of this, LVL 195 million (€279 million) can be attributed to operations backed by the Treasury bills issued specifically for liquidity support of Parex Bank. In addition, earlier in the year the BoL released LVL 200 million in liquidity by lowering reserve requirements; further cuts in November and December release an additional LVL 380 million.

- Increased liquidity has reduced central bank foreign exchange reserves. Since end-August the BoL has sold around $€ 900 \mathrm{~m}$ in foreign currency: just under a quarter of official reserves.

- An additional (prospective) balance of payments risk comes from Latvian banks' need to rollover $€ 1.4$ billion of syndicated loans (roughly 5 percent of their liabilities) in the coming year.

\section{Initial responses to Parex Bank's growing illiquidity failed to stem the deposit}

run. At first the government reached a voluntary agreement with the former shareholders to take over only 51 percent of the bank. This agreement would have allowed the former owners to remain on the management board and retain significant influence over the bank's operations, and also granted them the right to buy back their shares one year later. This approach, which the authorities believed would persuade non-residents to keep their deposits, failed to stem the outflows. As a result, the authorities had to increase liquidity supportLVL 350 million ( $€ 500$ million or more than 2 percent of GDP) from the Treasury and a net LVL 200 million (1 1 $\frac{1}{4}$ percent of GDP) from the BoL - to meet the deposit outflow. On December 1, the authorities also imposed a partial freeze limiting withdrawal amounts from large non-commercial private deposits, to conserve liquidity in Parex. 
17. Left unresolved, Parex's problems could worsen the balance of payments crisis. Parex has $€ 775$ million (3 $1 \frac{1}{2}$ percent of GDP) of syndicated loans maturing in February and June 2009 , in addition to its $€ 200$ million Eurobond which is potentially callable. Thus risks in Parex could lead to a $€ 1$ billion capital outflow.

\section{The Authorities' Program}

18. The authorities' program aims to stem the current liquidity crisis and then ensure long-term external stability, while maintaining the exchange rate peg:

- The immediate objective is to stabilize the financial sector, restore depositor confidence, and avoid the disorderly adjustment that would follow if the exchange rate peg were abandoned. To maintain the peg, the program includes measures that ringfence and resolve the immediate problems in Parex Bank, to prevent contamination to the rest of the system ( $\mathrm{LOI} q 3) .{ }^{1}$ It also draws on substantial outside international financial assistance to meet the demand for foreign exchange.

- For the medium-term, the program includes measures to promote economic adjustment and strengthen the peg. The program includes measures to restore confidence in the broader financial system, to halt the drain of external liquidity. Substantial fiscal policy tightening will reduce financing needs, foster real depreciation, and make room for potentially large contingent financial sector liabilities. The program's aim is to meet the Maastricht deficit criteria to facilitate adoption of the euro. This exit strategy should help prevent a recurrence of the current difficulties. The program includes strong incomes policies to reduce inflation and improve competitiveness, and structural policies that should boost productivity growth and help generate the much-needed shift from non-tradables to tradables production. Private sector debt restructuring will also likely be needed.

- The authorities' unequivocal commitment to the exchange rate peg has determined their choice of program strategy. Though this commitment augurs well for program ownership, the authorities also recognize that their choice brings difficult consequences, including the need for fiscal tightening and the possibility that recession could be protracted, perhaps more so than if an alternative strategy had been adopted.

\section{A. Monetary and Exchange Rate Policy}

19. The macroeconomic framework is centered on maintaining Latvia's quasicurrency board at the current exchange rate parity (LOI $₫ 19-20)$. While an exchange

\footnotetext{
${ }^{1}$ Numbers refer to paragraphs in the Letter of Intent.
} 
rate adjustment may have some advantages (notably, a quick correction of Latvia's real exchange rate misalignment), it also would come with considerable risks:

- A change in the peg is strongly opposed by the Latvian authorities and by the EU institutions, and thus would undermine program ownership. The quasicurrency board has been an anchor of macroeconomic stability for more than 15 years, was able to withstand the 1998 Russian crisis, and commands popular and political support. Any change in regime would cause significant economic, social and political disruption.

- Devaluation would create large balance sheet effects, with a risk of negative feedback loops. Some 70 percent of bank deposits and nearly 90 percent of loans are foreign currency denominated. With private sector net foreign currency debt of around 70 percent of GDP, any change in the nominal exchange rate would lead to an immediate deterioration in private sector net worth.

- External financing needs might not be significantly reduced. While devaluation would shrink the current account deficit, private sector roll-over rates might not improve, as the external debt to GDP ratio would increase sharply.

- Given the fragile global funding environment, the spillover risks increase for other emerging European economies, especially in the Baltics and South-Eastern Europe. Furthermore, loan losses in Nordic banks that have invested in the Baltics could hurt market confidence in these banks, which are already fragile because of their substantial dependence on wholesale financing.

20. The authorities and staff examined the merits of alternative exchange rate regimes. A widening of the exchange rate band to \pm 15 percent (as permitted under ERM2; currently Latvia has unilaterally adopted a \pm 1 percent band) would result in a larger initial output decline, since adverse balance sheet effects would reduce domestic demand. However, competitiveness would improve more quickly, reducing the current account deficit and fostering a more rapid economic recovery (Box 1). The case for changing the parity would be stronger if it could be accompanied by immediate euro adoption. Technically, this would address many of the risks described above, and give Latvia deeper access to capital markets. With its negligible public sector debt, the government would also find it easier to borrow in euros on international capital markets. However, the EU authorities have firmly ruled out this option, given its inconsistency with the Maastricht Treaty and the precedents it would set for other potential euro area entrants.

\section{B. Macroeconomic Framework}

21. If Latvia's exchange rate peg is to be maintained, domestic policies need to be radically strengthened to generate the needed real depreciation. Under the peg, real 
exchange rate overvaluation would need to be addressed through a prolonged process of factor price adjustment (Box 2). This will likely require a recession in the short run, and slow growth for several years to come.

22. The authorities' program therefore assumes cautious macroeconomic targets for 2009-2010 (Table 8; LOI 9|8-9). Continued weakness in the global economy, financial market deleveraging, and liquidity strains in the CIS countries (the source of most nonresident deposits) will reduce external financing and result in recession:

- Real GDP is expected to continue declining through 2010. Falling nominal wage growth and rising unemployment will erode household incomes leading to a large drop in private consumption. With Latvian banks unable to lend, investment spending will fall sharply. Output is expected to drop by 5 percent in 2009 and a further 3 percent in 2010, before growing in 2011.

- $\quad$ From double digits in 2008, inflation falls sharply. Year average inflation in 2009 drops to just under 6 percent, while December year on year inflation falls to just above 3 percent, despite increased indirect taxes and administered prices. Latvia should come close to meeting the Maastricht inflation criterion by end-2010.

- Despite the unfavorable external environment, the current account deficit is projected to decline from $143 / 4$ percent of GDP in 2008 to $7 \frac{1}{4}$ percent in 2009. The main cause is a continuing fall in imports as lending and output contract.

- The capital and financial account drops from a $€ 2.2$ billion surplus in 2008 to a €2.2 billion deficit in 2009. FDI declines considerably, and trade credit contracts in line with import compression. Net short-term capital outflows rise sharply as nonresident deposits are withdrawn due to outside liquidity needs.

- Given the difficult international conditions, bank rollover rates are projected to decline. The program assumes 80 percent rollover for foreign-owned banks and their subsidiaries, and 40 percent for state-owned and domestic banks without a foreign affiliation.

- Corporates are assumed to be able to rollover only 40 percent of their external debt. This is based on: (i) relatively high ( 75 percent) rollover rates on debt owed by non-bank financial institutions to their foreign parents; (ii) 50 percent rollover rates for loans of public companies; and (iii) considerably lower rollover rates for the debts of real estate and construction firms, which will be hard hit by the recession.

23. Over the medium-term, the program projects a gradual but moderate economic recovery (LOI 910$)$. Easing of global deleveraging pressures and recapitalization of Latvian banks should cause external financing and domestic lending to resume. Increased EU grants 
will boost investment. The sharp slowdown in wage and price inflation will deliver a gradual improvement in competitiveness and higher net exports. However, weakness in disposable incomes and continued fiscal restraint slow consumption growth. Positive output growth should resume from 2011, but below Latvia's long-term potential.

\section{Financial Sector Reform}

\section{The authorities' first priority is to arrest the deteriorating conditions in Parex} Bank, as the rest of the banking system so far has been able to meet increased demands for liquidity (LOI q12). This is critical for slowing the loss of deposits and international reserves, and also for helping to restore confidence to the financial system. The authorities have a clear strategy for doing this, which takes into account Parex's systemic nature:

- $\quad$ On December $5^{\text {th }}$ the government completed the takeover of 85 percent of the shares. It appointed new professional management to run the bank, which is negotiating with loan syndicates and major depositors steps to preserve the bank's stability and renew funding.

- $\quad$ Emergency legislation has been submitted to Parliament permitting government intervention and full bank takeover, in cases where this is needed for the stability of the banking system and smooth operation of the payments system.

- $\quad$ Once the government has full ownership of Parex, the staff recommends that it should err on the side of overcapitalizing the bank, by raising its capital adequacy ratio to at least 12 percent (provided the due diligence report suggests the bank has positive value as a going concern), given the risks posed by its reliance on short-term external funding.

- $\quad$ After the bank is stabilized, the management will develop a clear (and transparent) strategy that returns the bank to the private sector. This should be done as quickly as possible, to minimize the risk that the bank will lose value (as can often happen when in state hands). EBRD participation might also help boost capital and liquidity. Management will also need to work to lengthen the maturity of its liabilities, both deposits and syndicated loans, so that they can be repaid in an orderly manner. The partial deposit freeze would be lifted once the pressures for outflows ease and there are good prospects that stability can be maintained.

25. The program also aims to reduce vulnerabilities in the rest of the banking system (LOI q13). The Financial and Capital Markets Commission (FCMC) will supervise a targeted examination of the banking system by independent auditors. It will focus on domestic banks that rely (like Parex) on short-term external funding (three such banks hold 13 percent of banking system assets, and close to 20 percent of deposits). Based on this analysis, the government and FCMC will work with viable banks to make sure they have 
sufficient capital including, if necessary, through design of a public capital support scheme with appropriate terms and eligibility conditions, in line with international best practice. To safeguard public resources, the authorities will consult with staff before using public funds for recapitalization. They will also review and if necessary revise the regulations on liquidity support.

26. Over the medium term, the regulatory approach towards banks that deal primarily with non-residents should be reconsidered to reflect the higher liquidity and market risks of their business model. Banks may need to reduce maturity mismatches created by such deposits, and ensure that they have sufficient and liquid foreign assets to meet potential depositor withdrawals. The FCMC should enhance its monitoring to ensure that these banks retain sufficient liquidity buffers, and be pro-active in using its existing powers to request additional capital where warranted. These steps could help insulate the domestic economy from future volatility in external funding.

\section{The program includes clear commitments from foreign banks to maintain their}

presence. To solve the collective action problem and discourage individual banks from withdrawing credit lines, Swedish (and other Nordic country) parent banks have issued public statements with commitments to support their investments in the Latvian banking system, and to make strong efforts to maintain their credit activities in the country. The parent banks also intend to at least maintain the existing capital adequacy of their subsidiaries, recapitalizing them where necessary. Adherence to these commitments will be monitored under the program.

28. In light of recent strains, the program includes measures to strengthen the authorities' crisis response capacity, in line with earlier Fund recommendations (LOI q14). The FCMC will enhance its monitoring capacity of individual banks, and improve information sharing with the BoL (especially on amounts of liquidity support) and home supervisors of foreign banks. With its reserves bolstered by international financial support (including a new $€ 500$ million swap line with the Swedish and Danish central banks), the BoL should be ready to lend to illiquid banks against an expanded range of appropriate collateral, provided the bank is solvent. Strengthening the Deposit Guarantee Fund and ensuring its adequate funding, should make reimbursement of insured deposits faster and automatic (through an agent bank).

\section{Private Debt Restructuring}

29. Private debt restructuring will be an important component of the program to mitigate risks to solvency (LOI q16-18). Much of Latvia's high external debt has a domestic debt counterpart, since it is owed to foreign parent banks and then onlent to Latvian households and corporations. The gathering recession will make debt servicing more difficult and increase the proportion of nonperforming loans. As almost all of this debt is owed by the 
private sector, restructuring will be difficult. Nevertheless, the authorities have committed to developing a comprehensive private debt restructuring strategy by end-April 2009.

30. While the details of the strategy will need to be developed in the next few months, main elements are likely to include:

- $\quad$ Amending the insolvency law to facilitate workouts between viable enterprises and their creditors by end-June 2009. For maximum economic benefit, the key is to differentiate between non-viable firms (which should be liquidated) and viable firms (which are candidates for rehabilitation). Legal reforms could include expedited court approval of rehabilitation plans and according priority status to new financing, to support rehabilitation of viable firms. Aside from refining the insolvency law, a concerted information strategy to optimize out of court restructurings would be helpful, so that the courts are not overwhelmed.

- Improving the personal bankruptcy framework to help the rehabilitation of household debtors. Streamlined procedures, debt counseling and timely participation of creditors can address individual insolvencies effectively. Given the substantial decline in real estate prices, reforms that encourage loan modifications should be explored. Amendments to the insolvency law, due by end-June, will be part of this reform.

- Strengthening banks so that they can restructure their debts. Parent banks would be expected to absorb loan losses in their Latvian subsidiaries. Among domestic banks, insolvency procedures will take care of private debt restructuring for those that are non-viable (while respecting payment system and deposit insurance considerations). Creditors of viable banks could support bank recapitalization through debt-equity swaps (possibly facilitated by tax and regulatory incentives). Bank recapitalization and transfer of bad assets and NPLs to an independent asset management company could also enhance banks' capacity to restructure their debts.

In addition, in developing the strategy consideration will need to be given to whether a caseby-case approach alone can be sufficient, or whether more comprehensive approaches (such as, for instance, the creation of an asset management company) will be needed.

\section{E. Fiscal Policy}

31. Without a change in policy, next year's fiscal deficit was set to reach double digits. The 2009 budget passed in November targeted a 1 percent of GDP fiscal deficit, but was based on overly optimistic assumptions. Both the 2008 deficit (now expected to be 3 percent of GDP, compared to the budget balance assumed earlier) and the 2009 growth projection (now projected at -5 percent, compared to -1 percent earlier) are now much worse. With indirect tax revenues plummeting (Figure 5) and corporate income tax revenues set to collapse as profits fall, left unchanged, the 2009 budget would have resulted in a 12 percent 
of GDP fiscal deficit. In addition, substantial contingent fiscal liabilities from the financial sector are likely. This deficit would have been extremely difficult to finance.

\section{In response, the authorities' program includes substantial and front-loaded} fiscal tightening that limits the deterioration in the budget deficit (LOI q22-26). On December 11 Parliament adopted a revised budget with 7 percent of GDP in measures, to target a 4.9 percent of GDP deficit. Roughly $1 / 3$ of the adjustment comes from revenue measures (increases in VAT and excises), and $2 / 3$ from cutting expenditure (reducing public sector nominal wages - see the section on incomes policy below - and a 25 percent real cut for most current spending). This fiscal consolidation will reverse a period of accommodative, unsustainable fiscal policy, when excessive structural deficits had been disguised by Latvia's rapid growth rates. The adjustment will be line with the experience of successful large-scale fiscal adjustments (Box 3). It should have a moderate impact on short-term growth, but contribute to the real depreciation imposed by the current exchange rate arrangement, and eventually foster growth.

33. As in other large fiscal adjustments undertaken when initial economic conditions are exceptionally difficult, positive macroeconomic impacts should dominate over the medium term. Rationalized government expenditures and higher taxes will reduce aggregate demand, promoting a more viable external current account and a more sustainable debt burden, and lowering the risk premium.

34. Short-term contractionary effects should remain moderate. Cuts in productive government investment, which are known to induce a much sharper short-run negative impact on economic activity, are protected under the program. Large reliance on consumption taxes increases should also help to mitigate the GDP contraction, reflecting the broad base of these taxes and their relatively low distortion effects. However, because of the quasi currency board arrangement, monetary policy cannot offset the fiscal tightening; short-run contractionary effects will be compounded by the inability of households to smooth consumption through credit. This suggests that fiscal multipliers should remain positive in the short run, by contrast with episodes in Ireland and Denmark in the 1980s (Guavas and others, 2000). Finally, as in other small, open economies, the impact of fiscal policy is limited by the large impact of the external sector, and may be further impeded by significant leakages in tax collection. 
Composition of the Fiscal Adjustment (change in the primary balance), 2009-10

\begin{tabular}{|c|c|c|c|c|}
\hline & \multicolumn{2}{|c|}{ In percent of GDP } & \multicolumn{2}{|c|}{ In percent of adj. } \\
\hline & 2009 & 2010 & Latvia, 2010 & Ref. 1/ \\
\hline $\begin{array}{l}\text { Total consolidation } 1 / \\
\text { (cumulated) }\end{array}$ & $\begin{array}{l}7.1 \\
7.1\end{array}$ & $\begin{array}{l}1.1 \\
8.2\end{array}$ & 100.0 & 100.0 \\
\hline Revenue & 2.5 & 0.9 & 41.9 & 24.4 \\
\hline Direct taxes on income, profits and capital gain & -0.2 & 0.8 & 7.9 & 4.6 \\
\hline -of which: Inc. tax base on capital income and property & 0.0 & 0.9 & 10.4 & $\cdots$ \\
\hline Indirect taxes & 2.4 & 0.1 & 29.8 & 8.5 \\
\hline Domestic taxes on goods and services, inc. VAT & 1.9 & 0.0 & 23.7 & 6.1 \\
\hline Taxes on international trade, inc. excise & 0.5 & 0.0 & 6.1 & 2.4 \\
\hline Non-tax revenue (fees, dividends), grants and other & 0.3 & 0.0 & 4.2 & 11.3 \\
\hline Expenditure & 4.6 & 0.1 & 58.1 & 75.6 \\
\hline Primary current expenditure and net lending & 4.6 & 0.1 & 57.0 & 48.1 \\
\hline -of which: wages & 1.3 & 0.4 & 20.8 & 9.4 \\
\hline Capital expenditure & 0.0 & 0.1 & 1.1 & 27.5 \\
\hline
\end{tabular}

Sources: "Experience with large fiscal adjustments", and Fund staff estimates.

$1 /$ Sample of 66 fiscal adjustments with no or small reversal in the first three years of the adjustment.

\section{The program's revenue measures build on the improvement of the tax system}

initiated in 2008. Revenue-based adjustments rely to a significant extent on base broadening and simplifications of the tax system. Latvia will shift about 4 percent of GDP from direct to indirect taxes between 2008 and 2011, while broadening the direct tax base for capital gains and real estate taxes in 2010. Tax collection will also improve. Tax policy changes are designed to re-direct resources towards the tradable sector, and from consumption to production.

\section{Though the program's expenditure measures are substantial, they are also} selective, and supported by institutional changes. Although across-the board spending cuts can curb expenditure in the short run, they tend to have significant efficiency costs over the longer term and lead to the accumulation of arrears. To avoid this problem, December's initial 2009 supplementary budget (which includes clear overall spending targets, which now need to be backed by more specific measures) will be followed by a more detailed supplementary budget in the first quarter of 2009. Latvia's expenditure adjustment departs significantly from typical consolidations, by protecting social spending (Box 4) and capital outlays, and by making larger cuts in the wage bill. EU-related expenditures are also rigid because they are needed to secure future EU transfers.

37. Major structural reforms will buttress these cuts. Successful fiscal consolidations often rely on support of structural reforms in the areas of health care, unemployment benefits, and pensions. Latvia's consolidation plan includes, in addition, comprehensive reforms of the state and local administrations, education system, and civil service, which have all been prepared in recent years. After being frozen in 2009, pensions indexation will also be reformed. 
38. Local governments will play an important role in the consolidation. Key issues include clarification of expenditure responsibilities and revenue assignments of sub-national governments, and the coordination of the fiscal policy between these levels. On

December 10, the government signed a protocol with local governments on consolidation measures, specifying measures that local governments need to take as part of the fiscal adjustment, including nominal wage cuts in line with those in the central administration. Local government budgets will also be constrained by fiscal rules, including a golden rule preventing current spending from being covered by borrowing, and a global ceiling on local government borrowing of 0.3 percent of GDP in 2009, limited to EU projects. The revenuesharing agreement with municipalities will be revisited in the first semester of 2009 as part of the reform of local administration.

39. The program includes institutional changes to strengthen fiscal policy. Adopting fiscal rules, especially with embedded expenditure targets, introducing a medium-term budget framework and strengthening public financial management systems have helped consolidation efforts in several countries. The government intends to prepare a fiscal responsibility law in the first semester of 2009, which will focus on increasing transparency and accountability and strengthening budget systems. For the medium-term, the guiding fiscal policy objective is to meet the 3 percent of GDP Maastricht criterion as soon as reasonably feasible (LOI -28). A strong medium-term fiscal anchor will help meet this goal; it will also reduce procyclicality in fiscal policy. As a first step, the authorities have already requested technical assistance from FAD to strengthen public financial management systems. They are also likely to seek World Bank advice on structural reform and improving the efficiency of public expenditure, to make best use of the tighter budget envelope (LOI $q 27$ ).

\section{Restructuring actions of domestic banks will increase government liabilities and}

fiscal risks. Staff's preliminary estimates are that total fiscal costs of bank restructuring may fall between 15-20 percent of GDP through 2010, which would increase public sector gross debt above 40 percent of GDP. This estimate includes capital injections and liquidity support to troubled banks, and losses on guaranteed deposits. The fiscal cost would be twice as large as during the 1990s Baltic banking crises, and may eventually fall close to the median cost of banking crises worldwide since 1970. Furthermore, additional restructuring costs may need to be borne by foreign private banks, and public sector contingent liabilities related to the banking sector would reach 20 to 30 percent of GDP during the period. 
Potential fiscal costs of banking crisis, 2008-10

\begin{tabular}{|c|c|c|c|c|c|c|c|c|}
\hline & 2008 & $\begin{array}{c}2009 \\
\text { (in millions }\end{array}$ & $\begin{array}{l}2010 \\
\text { of lats) }\end{array}$ & Total & 2008 & $\begin{array}{c}2009 \\
\text { (in percent }\end{array}$ & $\begin{array}{l}2010 \\
\text { of GDP) }\end{array}$ & Total \\
\hline Direct fiscal costs & 356 & 1,868 & 253 & 2,477 & 2.3 & 12.4 & 1.7 & 16.4 \\
\hline Capital injection 1/ & $\ldots$ & 560 & 100 & 660 & $\ldots$ & 3.7 & 0.7 & 4.4 \\
\hline Purchase of assets & $\ldots$ & $\ldots$ & 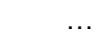 & 0 & $\ldots$ & & $\ldots$ & 0.0 \\
\hline Guarantees 2/ & $\ldots$ & 425 & 153 & 578 & $\ldots$ & 2.8 & 1.0 & 3.8 \\
\hline Other $3 /$ & 356 & 883 & $\ldots$ & 1,239 & 2.3 & 5.9 & $\ldots$ & 8.2 \\
\hline Contingent liabilities & 4,449 & 4,553 & 3,422 & $\ldots$ & 29.1 & 30.2 & 23.0 & $\ldots$ \\
\hline Deposits in Parex $3 /$ & 565 & 1092 & $\ldots$ & $\ldots$ & 3.7 & 7.2 & & $\ldots$ \\
\hline Uncovered liabilities of deposit insurance & 3,340 & 3,062 & 2,934 & $\ldots$ & 21.9 & 20.3 & 19.7 & $\ldots$ \\
\hline Potential guarantees & 544 & 399 & 488 & 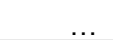 & 3.6 & 2.6 & 3.3 & \\
\hline
\end{tabular}

1/ Excluding capital injections by foreign shareholders, estimated at 9.7\% of GDP over $2009-2010$. $2 /$ Assuming a realization rate of $5 \%$, over $2009-2010$, on guarantees over deposits and of $50 \%$ on potential guarantees in 2009.

3/ Medium-term deposits in Parex are projected at 356 millions lats. Short-term deposits may reach 211 millions lats in 2008 and be rolled over onto 2009.

\section{F. Structural Reform and Incomes Policy}

41. Given the fixed exchange rate constraint, adjustment will depend on structural reforms to improve competitiveness and expand the tradable sector (LOI $129-30$ ).

Although Latvia has made considerable progress since independence in liberalizing its economy and improving its business environment, comparisons with other European countries show room for improvement. In recent years, easy availability of external financing may have led to reform complacency. Discussions with employer and investor associations suggest that governments focused too much on facilitating real estate investment, to the neglect of other sectors.

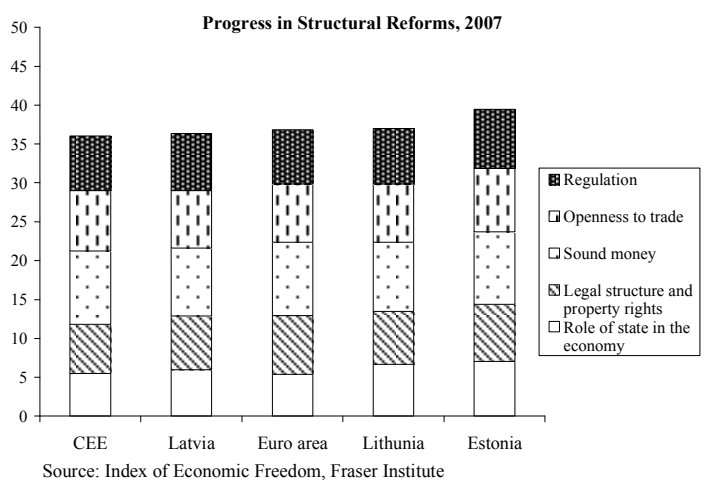
Business licensing can be cumbersome, particularly at the local level, and Latvia has not been as proactive as others in the region in attracting flagship investment projects.

\section{The program takes first steps towards addressing these weaknesses, but the} authorities will need to introduce further measures as the program develops. As part of its EU commitments, the government will implement its National Lisbon Program to boost competitiveness and productivity, and so reduce external imbalances. The European Commission will monitor these reforms.

\section{Strong incomes policies will be needed to reverse the excessive wage growth of} the boom years, which has resulted in exchange rate overvaluation. To improve competitiveness, the authorities are cutting wages and bonuses in the public sector by 25 percent in 2009 compared to 2008 . While the authorities only have direct control over wages in the central government, they intend to extend these wage reductions to state-owned 
enterprises and, by reducing transfers, also to local governments. Demonstration effects from these measures, together with the slowing economy, should also lead to substantial nominal wage cuts in the private sector. In addition, the authorities and the social partners are establishing a joint committee to promote wage restraint and strengthen competitiveness, including by publishing monthly progress reports with specific recommendations.

\section{For the medium term, the government is also prepared to explore reforms to the} wage-setting process to foster greater restraint. First steps include the creation of a committee within the existing National TriPartite Council, which will monitor the implementation of the wage-cutting measures in the public sector, and issue recommendations to bring private-sector compensation back to the level required to restore competitiveness. This initiative will promote greater transparency in wage setting and encourage workers to be more realistic in their wage demands. It will increase the efficiency of the existing decentralized wage bargaining system and help protect the fixed exchange rate.

\section{IV.Program Modalities}

\section{A. Access}

\section{Latvia faces considerable balance of payments financing needs through early-} 2011 (Table 9). With the current account deficit projected to decline to 71/4 percent of GDP in 2009 , gross external financing requirements are close to $€ 15$ billion through early-2011, and the net financing gap around $€ 7.5$ billion. This in itself requires implementation of a strong program based on: (i) fiscal tightening (though protecting the poor); (ii) ringfencing problem banks and strengthening the financial system, so raising rollover rates and encouraging nonresident deposits to remain; and (iii) incomes and structural policies to improve competitiveness.

\section{Commitments by the European Union, neighboring countries, the World Bank} and the EBRD, should fill the bulk of this gap:

- $\quad$ The European Union will provide $€ 3.1$ billion over the program period, including $€ 2.2$ billion over the next 6 months.

- $\quad$ The Nordic Countries (Sweden, Denmark, Norway and Finland) have agreed to provide up to $€ 1.8$ billion, and expect to disburse from early 2010 .

- The Czech Republic, Poland and Estonia have committed an additional $€ 0.2$ billion, $€ 0.1$ billion and $€ 0.1$ billion respectively.

- $\quad$ The World Bank and the EBRD will provide $€ 0.4$ and $€ 0.1$ billion in conjunction with support to the financial sector. 
47. To fill the remainder of this financing gap, and to support and help cushion the authorities' strong adjustment effort, exceptional access from the Fund in the amount of SDR 1.521626 billion (1200.02 percent of quota, or approximately $€ 1.7$ billion) will be needed (Table 10). Of this, it is proposed that the initial purchase under the Fund arrangement be up to SDR 0.54 billion. Already the Swedish Riksbank, in cooperation with other Nordic central banks, has opened a $€ 0.5$ billion swap line to bridge to this purchase. This reflects both the urgency of Latvia's balance of payments pressures, and the seriousness of the commitment of international partners to stabilize Latvia's economy. Although debt sustainability will need to be monitored carefully, staff assesses that Latvia meets the four criteria for exceptional access (Box 5).

48. The staff proposes that this exceptional access be on credit tranche terms. There is a presumption that exceptional access in capital account crises will be provided using resources of the Supplemental Reserve Facility (SRF) where SRF conditions apply. While Latvia is experiencing a capital account crisis, it also has a large current account deficit which the program aims to reduce. The SRF is geared towards "a large short-term financing need resulting from a sudden and disruptive loss of confidence reflected in pressure on the capital account and the member's reserves". However, given the seriousness of Latvia's problems and uncertain global financial markets, the balance of payments difficulties will likely have a longer duration than envisaged by the SRF. Therefore staff proposes a 27-month arrangement (by which time capital market access should have been restored, and the election cycle completed) with exceptional access under the credit tranche policies.

\section{B. Capacity to Repay the Fund and Risks to the Program}

49. Latvia's capacity to repay the Fund is expected to be adequate. By the end of the arrangement, Fund exposure is projected to be just below 8 percent of GDP, about 30 percent of gross reserves (Table 11). Public debt increases somewhat over the program (and there are also contingent banking sector liabilities), taking the external debt to GDP ratio to around 150 percent (because of the slowing economy), before falling steadily from 2011 onwards (Tables 13-14; Box 6). Even so, Latvia's strong commitment to the program and the likely improvement in global financing conditions in coming years provide assurances that it will be in a position to discharge its obligations to the Fund in a timely manner.

\section{However, the program faces considerable risks:}

- Correcting currency misalignment without nominal depreciation is extremely difficult, as experience from other currency board and fixed exchange rate countries continues to show. Large external financial support and sustained wage and fiscal discipline by both the private and public sectors are required. Failure could entail substantial reputational risks for both the authorities and international institutions. 
- Maintaining the peg also requires substantial political commitment. If this commitment were to falter, there is a risk that the execution of the difficult but necessary policies required under the authorities' program could also weaken. However, all political parties are strongly committed to the exchange rate peg. Thus the revised 2009 budget was passed by a 57-21 majority, despite the exceptional fiscal tightening measures it contained. Maintaining this commitment through an anticipated prolonged recession could be challenging.

- This political commitment needs to extend to local governments, since they account for one-third of government spending. Strengthening the control of local government spending will be essential to ensure that wages are brought under control. Local government borrowing needs to be contained to ensure that the deficit targets are not subverted. In the past local governments have funded projects off balance sheet, which may create additional contingent fiscal risk.

- $\quad$ The program will only succeed if the financial sector stabilizes. If liquidity problems in other banks were to emerge, or if non-resident depositors withdraw funds at higher than expected rates, then the financing gap will exceed program projections. Also since a prolonged recession could weaken bank balance sheets and worsen financial sector confidence, the authorities need to be pro-active in encouraging recapitalization. They also need to develop and then implement their comprehensive strategy for private-sector debt restructuring.

- Latvia's capacity to repay the Fund (and other external creditors) will depend on its success in rebalancing the economy towards tradable production. This will require sustained structural reform to improve competitiveness, given the constraints imposed by the peg.

- $\quad$ Regaining access to international capital markets will also be key, particularly medium- and long- term borrowing after the program ends.

51. Several features of the program are intended to mitigate these risks. The duration of the program - through March 2011 - encompasses the macroeconomic framework and the budget for 2011 (to be passed by end 2010). This will also cover the 2010 general elections. In addition, the inclusion of strong up-front actions, notably December's passage of budget amendments with fiscal measures of around 7 percent of GDP, together with the decision to take full government control of Parex, should restore confidence in the financial system. Fiscal restraint, incomes policy, financial sector reforms, and institutional improvements, supported by technical assistance and implemented during the program should improve confidence and help rebalance the economy. 


\section{Program Monitoring and Conditionality}

52. The SBA is expected to run over 27 months from December 2008 to March 2011

(Box 7). The size and timing of the disbursements will be designed to restore confidence to Latvia's banking system, and support economic policies during a period of global deleveraging and banking-sector uncertainty. The authorities will consult with staff on evolving risks and agree on policy adjustments needed to achieve the goals of the program.

53. Program performance will be monitored by quarterly reviews. The first review under the program will be set for mid-February 2009, based on end-December 2008 targets, while the second review is proposed for mid-May 2009, based on end-March 2009 targets. Conditionality focuses on measures critical for addressing Latvia's vulnerabilities. Some structural conditionality is appropriate given the financial sector reform and adjustment towards tradable production needed for the program's success. These conditions are part of a larger set of policies being undertaken with the support of the European Commission and the World Bank.

\section{Purchases under the Stand-By Arrangement will be subject to financial}

assurances reviews. The Lending into Arrears policy would apply so long as external arrears (which have arisen from the partial deposit freeze imposed by the government on Parex Bank) remain. The Lending into Arrears policy would subject each purchase under the StandBy Arrangement to a financing assurances review assessing whether Latvia continues to make a good faith effort to facilitate settlement of depositors claims. Also a safeguards assessment will be completed by the First Review.

55. The program includes the following quantitative performance criteria for endDecember and end-March (and indicative targets for the rest of 2009) on: (i) a floor on net international reserves of the BoL; (ii) a ceiling on net domestic assets of the BoL; (iii) a floor on the adjusted general government cash balance; (iv) a continuous performance criterion on the nonaccumulation of domestic debt arrears by the general government; (v) a continuous performance criterion on non accumulation of external debt arrears by the general government. There is also an indicative ceiling on the general government wage bill. The program also includes structural conditionality, based on the need to stabilize the financial sector (the immediate cause of the current balance of payments problems), to make sure the sizeable fiscal adjustment can be delivered, and to put in place a wage-setting mechanism in line with the fixed exchange rate regime.

\section{Staff Appraisal}

56. Latvia faces intense liquidity pressures and needs to take steps to address concerns over external debt sustainability. These strains were triggered by the impact of global financial turmoil on the banking sector, which is highly dependent on foreign funding. 
However, the underlying cause of these problems is the build-up of vulnerabilities during the post EU accession boom, which left banks and the private sector highly indebted and unprepared to cope with a sudden stop of capital inflows. These problems are exacerbated by the high level of external debt and an overvalued currency.

\section{Latvia's difficulties elevate contagion risks for neighboring countries. Left}

unaddressed, the current pressures would soon result in a disorderly adjustment, including the unhinging of Latvia's fixed exchange rate against the euro. Given the fragile global environment, this could spill over into other emerging European economies with similar vulnerabilities, as well as to West European countries whose banks are exposed to the region.

58. The authorities' program for restoring stability and ensuring debt sustainability is centered on maintaining the existing exchange rate peg. The authorities are aware that, given the misalignment of the real exchange rate, adjustment will have to rely on a lengthy period of factor price compression, including reductions in real and nominal wages. This approach brings risks, but enjoys strong political support in Latvia and European neighbor countries, and a technically more attractive alternative - accelerated euro adoption at a depreciated exchange rate - is not consistent with EU rules. The approach also has the important advantage of avoiding the contagion risks that would emanate from an exchange rate adjustment in Latvia.

\section{Exceptionally strong domestic policies will be required for such a strategy to} work. The authorities recognize this, and have put in place ambitious fiscal and incomes policies that are targeted at improving competitiveness and delivering rapid external adjustment. They are also planning comprehensive financial sector reforms that aim at preventing a recurrence of the present problems. Implementation of these policies will be challenging and calls for broad political support. The authorities will need to forcefully communicate the benefits of maintaining the peg, and the unsustainability of economic policies followed during the boom, which have contributed to the current problems.

\section{The authorities' strategy depends on the successful implementation of a large} and sustained fiscal adjustment. The authorities' plans envisage a sizeable improvement in the structural balance between 2008 and 2011. This ambitious consolidation implies considerable negative fiscal stimulus, but is needed to support the exchange rate and weather financing pressures. Although tax increases are envisaged, the bulk of the adjustment will come from expenditure cuts, to be supported by institutional and structural reforms. Experience with episodes of large-scale fiscal adjustment suggests that this approach is much more likely to succeed than a strategy based primarily on revenue or one-off measures.

\section{Expenditure cuts are necessary but should be structured to support long-term}

growth and respect social objectives. Since Latvia has substantial needs for capital investment, the authorities are right to protect expenditures that cofinance EU-funded projects. In view of the likely increase in social hardship as unemployment rises and personal 
incomes decline, staff also supports the protection of social spending embedded in the program.

62. In the financial sector, the first step to solving the immediate liquidity crisis is to address the problems in Parex Bank. A successful resolution of this Bank-the secondlargest in Latvia-is a pre-requisite for restoring confidence in the system as a whole. The authorities, after some initial missteps, have now credibly moved towards stabilizing Parex, including by taking control of the bank and installing a new management. A clear exit strategy that minimizes losses to the state and protects depositors needs to be developed and implemented as a matter of urgency.

\section{More generally, a comprehensive set of reforms is needed to stabilize the}

financial sector. The current crisis has unveiled a number of weaknesses, both in the banking system itself and in the way it is supervised. The FCMC should immediately launch a focused examination of the banking sector, and where appropriate require banks to increase capital. Crisis management capacities need to be strengthened by enhancing the FCMC's ability to monitor the financial system, clarifying procedures for providing emergency liquidity assistance, and introducing legislation that allows the authorities to react more quickly to systemic crises. Taken together, these measures should significantly lower financial sector risk.

64. The imposition of a partial deposit freeze by the government on Parex Bank gives rise to an exchange restriction subject to Fund approval under Article VIII, Section 2(a). The new management that the government recently installed in Parex is actively engaging depositors affected by the exchange control to settle their claims. The authorities have taken some steps as described in paragraph 24 , and will implement additional measures, to resolve the liquidity crisis and restore confidence in the banking system, which will support their intention to remove the deposit freeze as conditions stabilize and clearance of private external arrears arising from this exchange control. Staff supports the authorities' request for temporary Fund approval of the exchange restriction in line with Fund policy, on the basis that it has been imposed for balance of payments reasons, it is temporary and is nondiscriminatory.

\section{The authorities also need to develop a strategy for addressing the substantial} external debt burden. This is necessary to secure long-term growth and reduce vulnerabilities. Much of this debt is rooted in banks' past excessive domestic lending and the related build-up of domestic debt by households and corporates. This debt overhang will be difficult to address given that it entirely involves the private sector. As a first step, the authorities will need to improve insolvency laws and establish other mechanisms for debt resolution, which are poorly developed in Latvia.

66. The longer-term success of the program will hinge on whether policies succeed in improving competitiveness. To achieve this, the authorities should use all legislative and 
persuasive tools at their disposal to ensure that substantial wage cuts in budget institutions are matched by local governments and state-owned enterprises. They also need to engage with the private sector to encourage similar wage restraint, and develop institutional structures that will moderate future wage growth. Although wage bargaining is decentralized and success is not guaranteed, Latvia has dealt with severe shocks before (such as the 1998 Russian crisis), and has been able to adjust successfully. This provides some confidence that the economy is flexible enough to master the needed adjustment while maintaining the peg.

67. Risks to the program are nevertheless considerable. Unlike previous countries emerging from crisis, Latvia will not be able to rely on a supportive external environment. The political momentum for reforms may fade, competitiveness may not improve decisively, and financial market confidence may not return quickly. The program therefore includes strong safeguards: external financing assurances to provide additional buffers and targeted conditionality, including passage of the ambitious supplementary 2009 budget as a prior action. Close monitoring will be required involving quarterly reviews, and there would be a need for substantial technical assistance to relieve institutional constraints to program implementation. Such close engagement will be crucial for the program's success and is warranted despite the resource implications for the Fund.

68. In view of Latvia's balance of payments needs, and the appropriately ambitious program put together by the authorities, backed by substantial financial assistance from Latvia's international partners, the Staff supports the Latvian authorities' request for a 27-month Stand-By Arrangement amounting to SDR 1.521626 billion. 


\section{Box 1: Alternative Exchange Rate Options}

In addition to maintaining the existing fixed (narrow-band) exchange rate, staff considered a number of alternative exchange rate options. These included, inter alia: (i) widening the current exchange rate bands to the full 15 percent range permitted under ERM2; and (ii) accelerated euro adoption at a depreciated exchange rate.

The main advantage of widening the bands is that it should eventually deliver a faster economic recovery. Although growth would be depressed in the short run by balance-sheet effects (see below), the economy might then bounce back more sharply, and a Vshaped recovery would likely start in 2010. This reflects a faster improvement in competitiveness since high pass-through (reflecting Latvia's openness to trade and liberalized movement of labor within the European Union) would be dampened by the negative output gap.

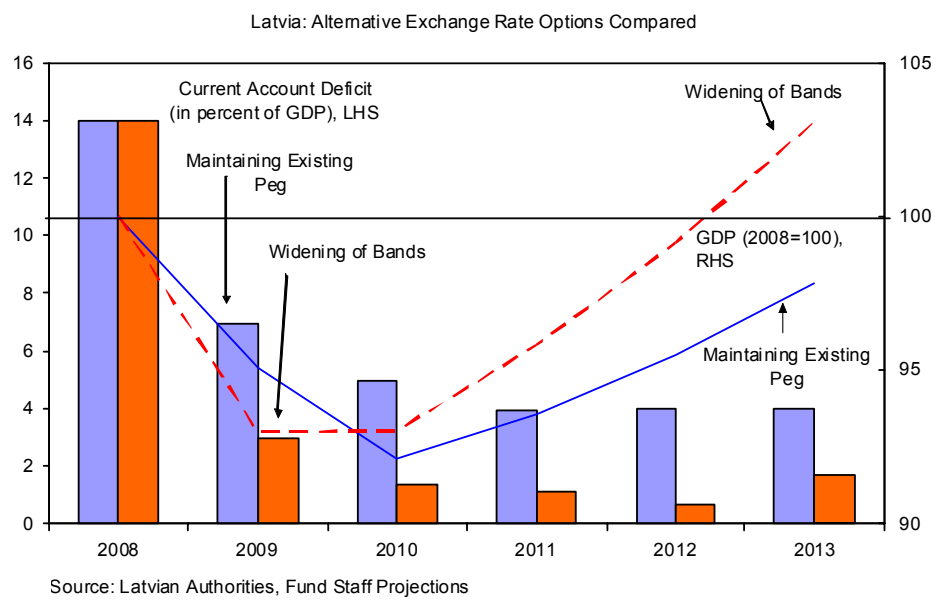
Enhanced competitiveness would also reduce the current account deficit more quickly. This would come mainly from import compression, with a relatively slow response of Latvia's underdeveloped export sector, especially as the external environment is not as supportive as in previous devaluation-induced recoveries as Argentina, Russia or East Asia.

However, balance-sheet effects would cause a sharp drop in domestic demand. The net foreign currency exposure of Latvia's private sector is around 70 percent of GDP, with the corporate sector's foreign

Net foreign currency exposure currency open position roughly (IIP data excluding portfolio assets; in percent of GDP) double that of the household sector's. A 15 percent devaluation against the euro would increase private sector net foreign currency exposure by 11 percent of GDP, two thirds in

\begin{tabular}{lccc}
\multicolumn{3}{c}{$\begin{array}{c}\text { Net foreign currency exposure } \\
\text { (IIP data excluding portfolio assets; in percent of GDP) }\end{array}$} \\
\hline & June 2008 & Devaluation (15 percent) & Change \\
\hline $\begin{array}{l}\text { Private sector } \\
\text { of which }\end{array}$ & 71.4 & 82.1 & 10.7 \\
$\begin{array}{l}\text { Private enterprises } \\
\text { Households }\end{array}$ & 46.4 & 53.4 & 7.0 \\
\hline
\end{tabular}
the corporate sector and one third in the household sector. Mismatches between owners of foreign currency assets and liabilities suggest that devaluation may cause substantial redistribution effects. Private consumption would fall by around 6 percentage points due to negative wealth effect as net foreign debt increases, house prices decline, debt service costs increase, and consumer confidence deteriorates. Experience of other countries suggests that a devaluation of this magnitude would lead to a 5 percentage point decline in private sector investment. 


\section{Box 1: Alternative Exchange Rate Options (Concluded)}

Widening the bands would carry significant and front-loaded risks. The fall in output would be deeper (because of balance sheet effects) and the economy would incur bank restructuring costs upfront, as loan defaults by unhedged firms and households would reduce bank capital. New bank lending would fall, slowing economic activity. A sudden stop in capital flows, which could follow depreciation, may exacerbate the credit crunch, and create negative feedback loops including renewed currency pressures. Possible regional contagion effects may make it difficult for foreign parent banks to support their subsidiaries.

Abandoning a regime that has provided an anchor for stability for more than 15 years (withstanding the 1998 Russian crisis), and which currently enjoys widespread popular and political support could undermine confidence. Regional contagion could spread to other countries, especially those in the Baltics and south-eastern Europe with similar vulnerabilities.

Accelerated adoption of the euro at a depreciated exchange rate would deliver most of the benefits of widening the bands, but with fewer drawbacks. Unlike all other options for changing the exchange rate, the new (euro-entry) parity would not be subject to speculation. By providing a stable nominal anchor and removing currency risk, euroization would boost confidence and be associated with less of an output decline than other options.

Euroization with EU and ECB concurrence would also help address liquidity strains in the banking system. If Latvian banks could access ECB facilities, then those that are both solvent and hold adequate collateral could access sufficient liquidity. The increase in confidence should dampen concerns of resident depositors and also help stem non-resident deposit outflows.

However, this policy option would not address solvency concerns and has been ruled out by the European authorities. If combined with a large upfront devaluation, there would be an immediate deterioration in private-sector solvency, which could slow recovery. Privatesector debt restructuring would likely be necessary. Finally, the European Union strongly objects to accelerated euro adoption, as this would be inconsistent with treaty obligations of member governments, so this option is infeasible. 


\section{Box 2: Cross-Country Evidence on Real Exchange Rate Adjustments}

Cross-country evidence indicates that there have been a number of episodes of important real exchange rate depreciation under currency pegs. However, in many of these cases, the real depreciation was achieved with help from outside forces, such as high inflation in trading partners or being pegged to a country that was not a dominant trading partner. The table below show countries with currency pegs that underwent real depreciations of 15 percent or more while preserving their pegs.

Table 1. Cross-country evidence on real exchange rate adjustments of countries with pegs 1 /

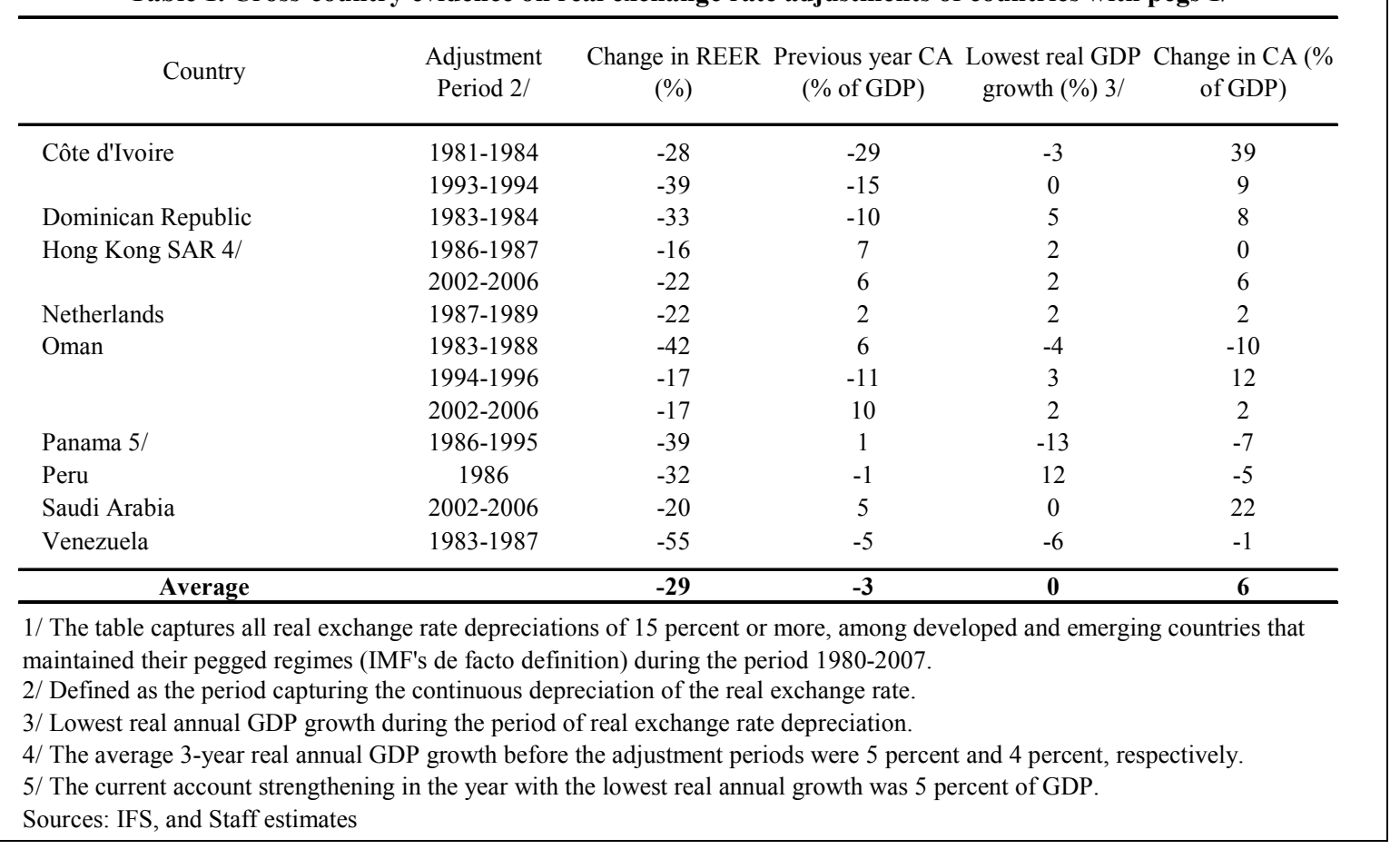




\section{Box 3. Latvia's Fiscal Adjustment in Historical Perspective}

Latvia's consolidation is relatively large. With the general government's structural primary balance improving by 14 percent of GDP between 2009 (constant scenario) and 2012, Latvia's fiscal consolidation plans would fall among the largest consolidation episodes in comparable countries during the past two decades, along with Denmark, Finland, Greece, New Zealand, or Sweden. Latvia's consolidation is twice larger than Lithuania's 1999-2003 adjustment motivated by EU accession. Similar results are obtained if one focuses on the primary balance of the central government.

\section{The consolidation will need to be sustained over 3-5} years. Successful consolidations tend to be gradual, spanning over a period of time that allows savings from structural reforms to materialize. Long consolidation episodes include Japan in the 1980's and Finland, New Zealand, Sweden, the United Kingdom and the United States in the 1990's. Latvia's consolidation is front-loaded, with three quarter of the structural adjustment happening in the first year versus 40 percent on average in comparable countries. However, articulated around the medium-term objective of meeting the Euro adoption criteria, Latvia's consolidation plan is expected to last three to five years, with savings from major structural reforms materializing progressively over 2010-2013.
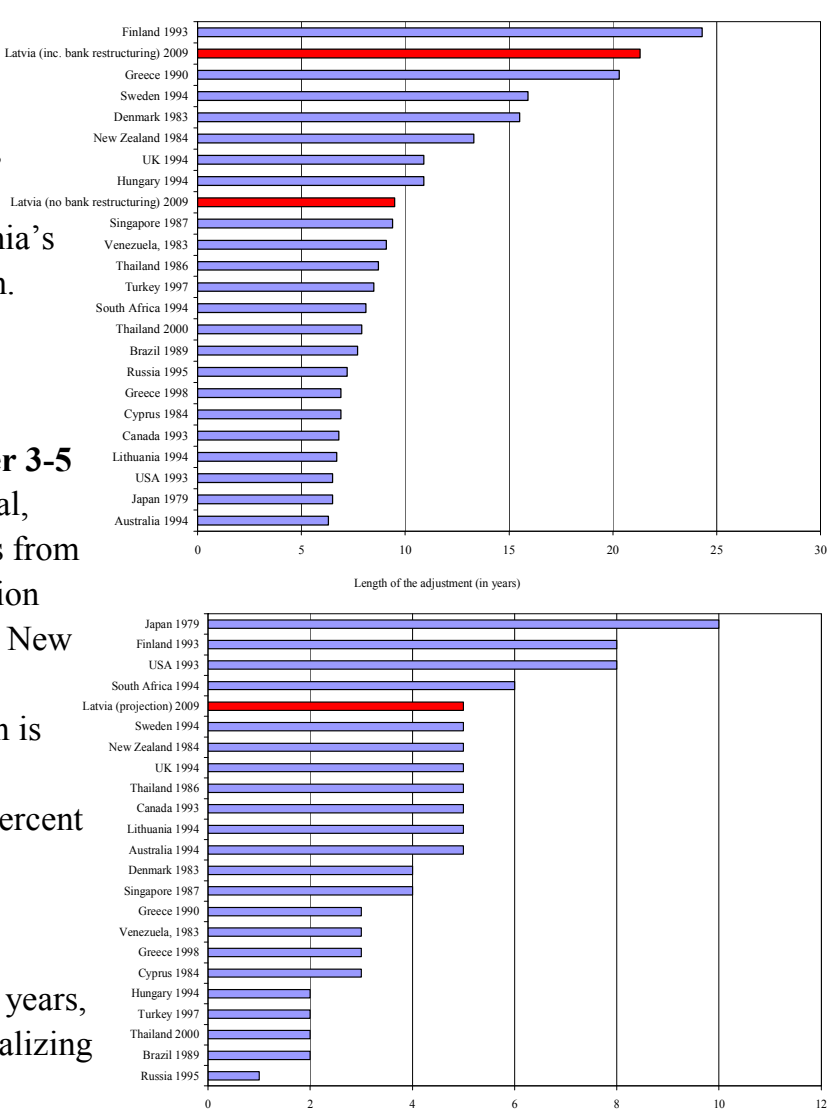

Latvia's approach is expenditure heavy yet more balanced than the average. The composition of consolidations is a crucial determinant of their success. Expenditure-based consolidations tend to be associated with deeper structural reforms increasing government productivity - more important than its size in ensuring sustainable growth and development — and to be eventually more successful. Revenue-based adjustments have a greater risk of reversal in industrial economies, but can be sustained when associated with tax policy or administration reforms, particularly in emerging market and developing countries. Latvia's consolidation is relatively expenditure-heavy, with 60 percent of the adjustment coming from expenditure cuts, but more balanced than the average.

Clear medium-term objectives, strong political leadership and mobilization of public support will be key. Consolidations tend to be more successful when perceived by markets and the population at large as durable and sustainable. In many European countries in the 1990s, consolidations were justified by the objective of the Euro adoption, which is also the case for Latvia. On the other hand, most consolidations tend to be led by new governments and under a broad consensus. Latvia's Parliamentary elections in 2010 represent a risk.

Selected sources: "Experience with Large Fiscal Adjustments", Occasional Paper No. 246; "Fiscal consolidation: Lessons from past experiences", OECD, 2007; "Fiscal Adjustments: Determinants and Macroeconomic Consequences", IMF WP 07/178, Kumar et al., 2007. 


\section{Box 4. Social Spending and Social Safety Nets}

Latvia's social spending will increase under the program from 21 to 25 percent of the budget. Total social spending will increase by $1 \frac{1}{2}$ percent of GDP between 2008 and 2009, to bring it closer with EU and OECD averages. Social spending is dominated by social insurance benefits, especially old-age pensions, which represent $2 / 3$ of total social transfers for the poorest quintile of the population.

The supplementary budget maintains the additional social measures approved in the initial budget law. Small pensions, the minimum wage, and personal income tax allowances will all increase significantly in 2009. Additional funds were appropriated for unemployment benefits and the State Employment Agency.

Social spending will be steered towards developing social safety nets. Poverty rates in Latvia are lower than most countries in the region and have significantly declined in recent years. However, targeting of Latvia's social programs could be improved and its social safety net spending is about $1 / 2$ percent of GDP below the European average. This is largely due to large income inequalities between local governments, which should be partially addressed as part of the local administration reform. The program also includes health sector reform, and additional measures to improve the targeting of the social benefits system should be included in the second supplementary budget for 2009.

Source: "Latvia—Sharing the High Growth Dividend: A Living Standards Assessment. Report," World Bank, 2007; and "For protection and promotion: the design and implementation of effective safety nets," World Bank, 2008. 


\section{Box 5. Exceptional Access Criteria}

The staff assesses that, on balance, the requirements of the exceptional access framework have been satisfied. Proposed total access under the SBA equals SDR 1.521626 billion (1200.02 percent of quota, or approximately $€ 1.7$ billion). Since both the cumulative and annual access limits under the program exceed normal access limits, evaluation under the exceptional access framework is required. The criteria under the exceptional access framework are as follows:

- Exceptional balance of payments pressure in the capital account. Latvia is suffering from significant nonresident deposit outflows beyond that which can be financed within normal limits. Loss of confidence in the banking sector together with global deleveraging and few prospects for external finance have resulted in large capital outflows, loss of reserves, and pressure on the currency.

- Sustainable debt position. Public debt is very low and is expected to remain sustainable: while it increases in the near-term (reflecting borrowing under the program), it is projected to decrease rapidly by 2013 (Table 12). The much heavier external debt burden is mostly concentrated in the private sector with a significant share (40 percent of total external liabilities, see Box 6) owed to affiliated banks and companies of foreign enterprises operating in Latvia. Though the external debt to GDP increases marginally over the next two years, it is also declining by the end of the program as public external debt is repaid. And, while stress tests and alternative scenarios show that Latvia's external debt remains vulnerable (Figure 10, Table 13), policies under the program will mitigate these risks. Moreover, the low public debt level provides room to the government to absorb some (foreign and domestic) private liabilities, should this be unavoidable, without threatening fiscal sustainability.

- Good prospects of regaining access to private capital markets. Latvia's loss of investor confidence is linked to global developments, though domestic banking problems have exacerbated this trend. The speed with which access to capital markets returns will depend in large part on global markets. Latvia has a strong track record in servicing its external debt. In staff's view, Latvia's access to private financial markets will likely be restored, particularly if international financial markets normalize, or if it is able to join the Euro area. The program assumes market access will be restored in 2011.

The policy program provides a reasonably strong prospect of success. Latvia's program is focused on three goals: maintenance of the exchange rate peg; macroeconomic stability; and eventual euro adoption. The program is supported at the highest political level, with cross-party support for maintaining the peg. While there are implementation risks given the appropriately ambitious program and the complex nature of the economic challenges being faced, Latvia has good institutional capacity to deliver the adjustment proposed under the program. 


\section{Box 6. External Debt Sustainability 1/}

Latvia's external debt ratio is high at around 130 percent of GDP. Under the staff's baseline projection it is set to rise further before declining rapidly after 2011 as the economy starts to recover.

Much of Latvia's external debt reflects borrowing by and from banks:

- Domestic financial institutions owe $2 / 3$ of the external debt, corporations another 30 percent.

- More than half the foreign debt is owed to banks. One-third of the external debt consists of foreign banks' loans to their subsidiaries or branches in Latvia. About 20 percent represents cross-border loans by unaffiliated foreign banks to Latvian banks. Non-resident deposits represent the third largest financing source, also about 20 percent of Latvia's external debt.

Table 1. Latvia: External Debt by Creditor, Jun-2008 1/

\begin{tabular}{lrrrr} 
& In millions of Lats & In million of USD & In percent of GDP & In percent of total \\
\hline & & & & \\
Affiliated Banks 1/ & 6,508 & 14,559 & 43.6 & 32.5 \\
Unaffiliated Banks & 4,324 & 9,673 & 29.0 & 21.6 \\
Non-Resident Deposits & 4,207 & 9,412 & 28.2 & 21.0 \\
Affiliated Corporates 2/ & 1,523 & 3,406 & 10.2 & 7.6 \\
Unaffiliated Corporates & 613 & 1,371 & 4.1 & 3.1 \\
Trade Credits received by corporates & 861 & 1,926 & 5.8 & 4.3 \\
Official Creditors 3/ & 540 & 1,208 & 3.6 & 2.7 \\
International Capital Markets & 844 & 1,889 & 5.7 & 4.2 \\
Other & 584 & 1,307 & 3.9 & 2.9 \\
Total external debt & 20,004 & 44,752 & 134.0 & 100 \\
\hline
\end{tabular}

Notes: 1/ Loans from foreign banks to their Latvian subsidiaries/branches

2/ Loans from foreign enterprises to their majority-owned Latvian subsidiaries

3/ Multilateral official creditors constitute almost all the official credit (99 percent)

Source: Latvian Authorities, Fund Staff Calculations

Figure 1. External Debt by Borrower and Currency Denomination, June 2008
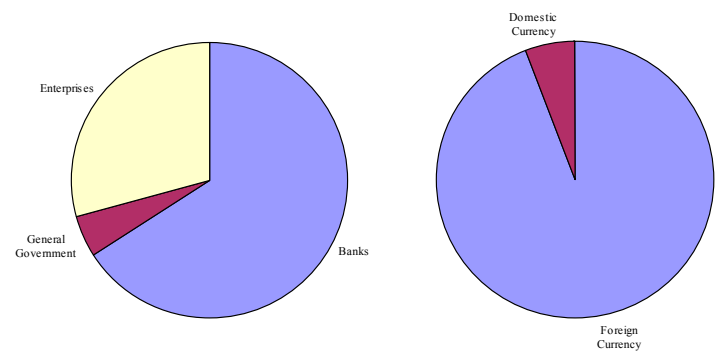

Most of the external debt is foreign-currency denominated and one-third is short term. This exposes Latvia to high currency and rollover risk in case of sudden shifts in confidence. Most of the short term external debt is concentrated in the banking sector, mainly non-resident deposits and foreign bank loans. Concentration of short term debt is not uniform: banks that rely on non-resident deposits are most exposed to rollover risk; subsidiaries and branches of foreign owned banks are less exposed to this form of risk.

1/ Draws on material prepared by Eugenio Cerutti and Guillermo Torosa (SPR) and an ad hoc Interdepartmental Working Group (EUR, LEG, MCM \& SPR) on Latvia's debt.

(Continued) 


\section{Box 6. External Debt Sustainability (Concluded)}

Figure 2. External Debt by Borrower and Maturity, June 2008
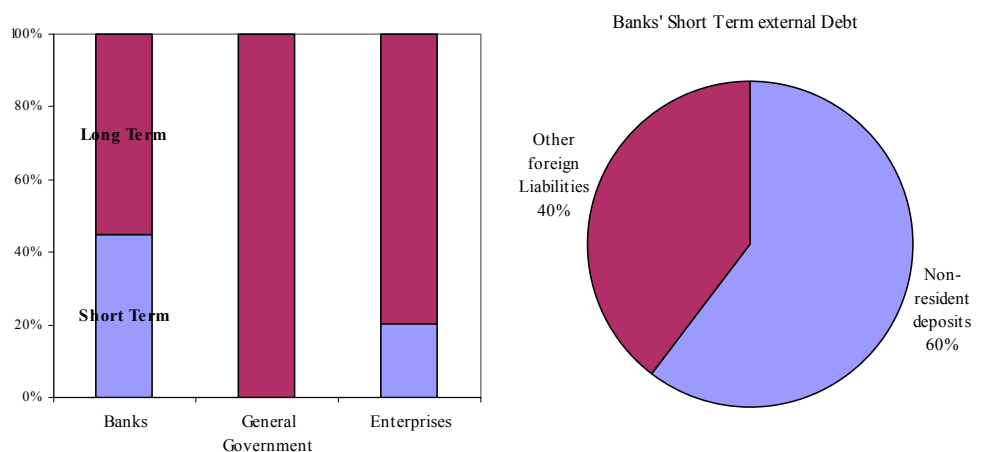

Domestic private debt is also high. Financed by foreign borrowing, bank credit to the private sector has grown rapidly during the last 5 years to reach 95 percent of GDP. Loans to households, mainly mortgages, represent 38 percent of total bank loans. Construction loans make up more than a quarter of corporate loans. Around 90 percent of loans are foreign currency denominated, creating mismatch vulnerabilities.

Using the standard debt sustainability analysis, external debt is projected to increase in the near-term before falling rapidly after 2011:

- The current account improves significantly as domestic demand falls and the economy enters recession. However, the fall in output means that the external debt to GDP ratio increases at first, before falling sharply in the out years as the economy recovers (Figure 10).

- $\quad$ Historical: if the economy were to perform based on 10-year historical averages, the debt to GDP ratio would fall steadily over the medium-term (top left), to just over 110 percent by 2013. This demonstrates the important role that the projected growth slowdown has on external sustainability.

- $\quad$ Shocks: standard shocks result in a deteriorating external debt position. In particular, a real depreciation shock would increase external debt to GDP significantly.

Finally, standard debt sustainability analysis may not capture all of Latvia's characteristics, given its dependence on foreign bank borrowing for credit intermediation and its role as an offshore financial centre. First, Latvia's net foreign debt is much lower (around 70 percent of GDP), as it reinvests many of the non-resident deposits in assets overseas. The value and liquidity of these assets then becomes key. Second, much of its foreign borrowing is backed by domestic assets. Thus external debt sustainability will depend on whether these assets recover value and will be able to generate future returns to service the debt. 


\section{Box 7. Latvia: Stand-By Arrangement}

Access: SDR 1.521626 billion (1200.02 percent of quota or approximately $€ 1.7$ billion).

Length: 27 months

Phasing: SDR 535 million will be made available upon the Board's approval of the arrangement to address the large balance of payments need in the fourth quarter of 2008 and to replenish reserves. The nine subsequent tranches will equal SDR 986 million. The next two tranches could be made available in February and May 2009, and quarterly thereafter.

\section{Program Conditionality}

\section{Prior Actions}

- $\quad$ Submission of resolution plan to FCMC by Parex management.

- $\quad$ Parliament to adopt 2009 supplementary budget capping general government fiscal deficit at below 5 percent of GDP.

- $\quad$ Government to sign protocol stipulating a 15 percent reduction in local government employees' average compensation.

\section{Quantitative Performance Criteria}

- $\quad$ Floor on net international reserves.

- $\quad$ Ceiling on net domestic assets.

- $\quad$ Floor on adjusted general government cash balance.

\section{Continuous Performance Criteria}

- $\quad$ Non-accumulation of domestic debt arrears by the general government.

- $\quad$ Non-accumulation of external debt payment arrears by the general government.

Quantitative Indicative Target

- $\quad$ Ceiling on general government wage bill.

\section{Structural Performance Criterion}

- $\quad$ Submission to Parliament of a second supplementary budget for 2009 to define spending allocations across ministries and spending agencies, and to identify clear programs that should be rationalized (March 31, 2009).

\section{Structural Benchmarks}

- $\quad$ Cabinet of Ministers to adopt decision that reforms controls over budget execution (December 31, 2008).

- $\quad$ Adopt operational guidelines clarifying procedures for provision of emergency liquidity assistance (December 31, 2008).

- $\quad$ National Tripartite Co-operation Council will establish a Committee to Promote Wage Restraint (January 31, 2009).

- $\quad$ Review and, if necessary, revise regulations on emergency liquidity support (January 31, 2009)

- $\quad$ Complete focused examination of the banking system (March 31, 2009).

- $\quad$ Develop comprehensive debt restructuring strategy (April 30, 2009).

- $\quad$ Amend banking laws to give FCMC, BoL and Government powers to restore financial stability in case of systemic crisis (June 30, 2009).

- $\quad$ Adopt an amendment to the Budget and Financial Management law to strengthen financial responsibility, transparency and accountability (June 30, 2009).

- $\quad$ Amend insolvency law to facilitate orderly and efficient debt restructurings (June 30, 2009). 
Figure 1. Latvia: Exchange Rate, Interbank Interest Rates, and Intervention

The lats has been at the depreciated end of its band since early October

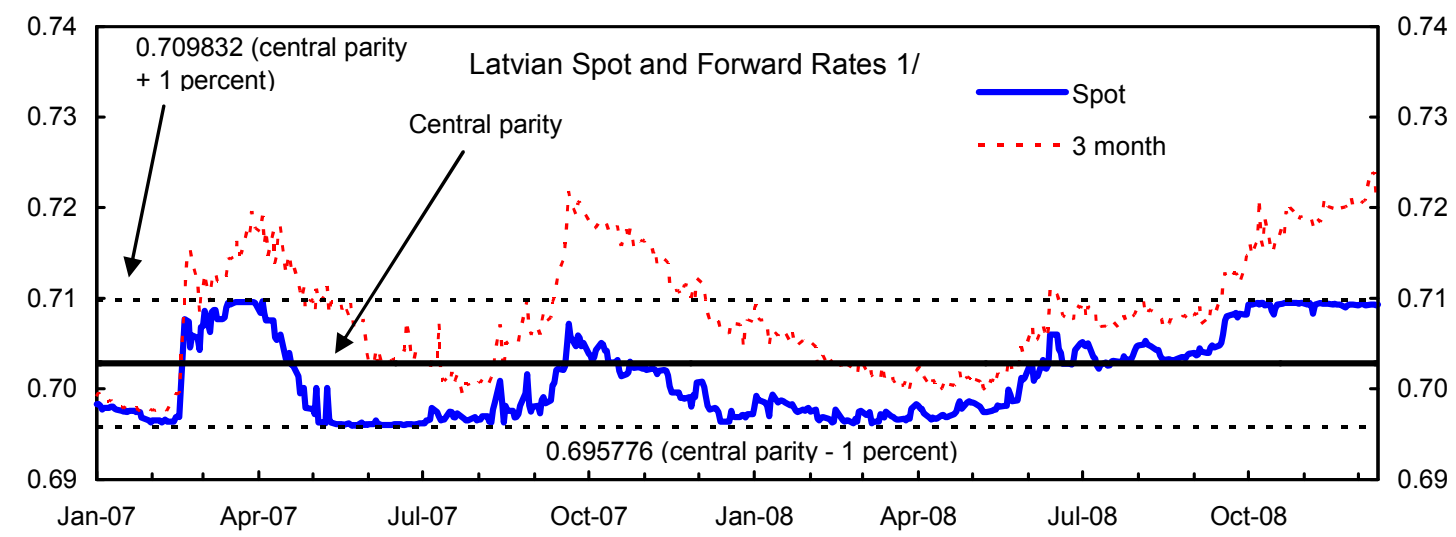

Interbank interest rates have spiked upwards

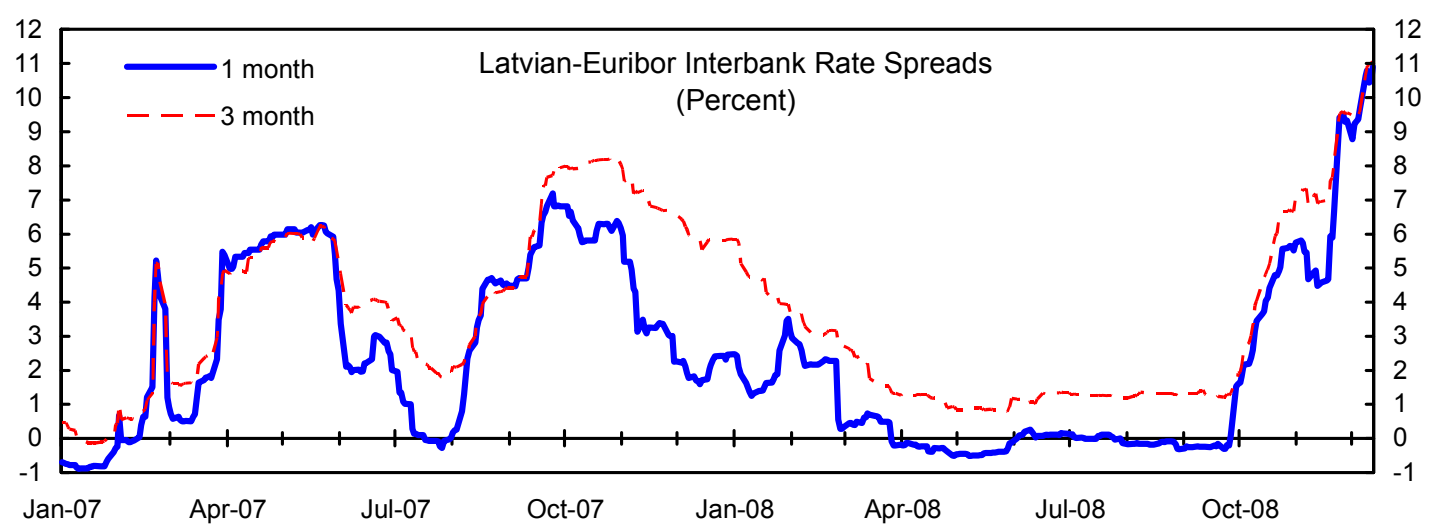

The Bank of Latvia has intervened heavily to defend the peg

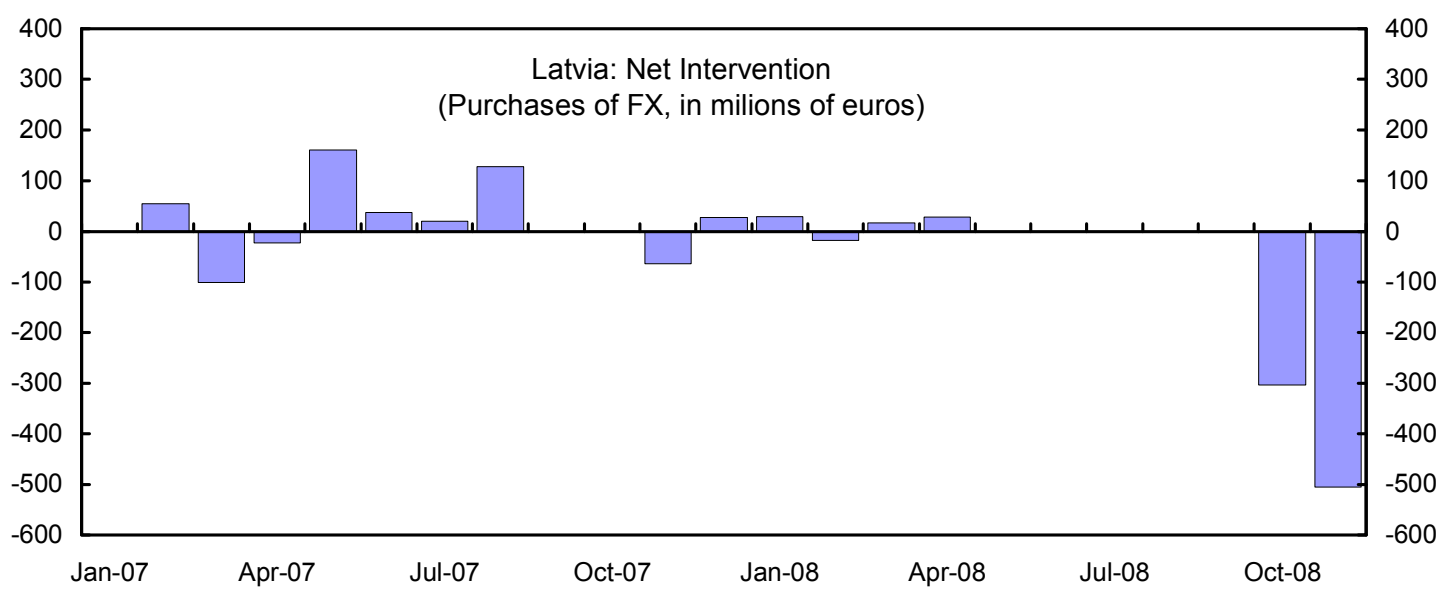

Source: Bloomberg, Datastream.

1/ Spot: lat-euro rate. Forward rates calculated as the product of the lat-US\$ forward rate and US\$-euro forward rate. 
Figure 2. Latvia: Real Sector, 2005-08

Domestic demand propelled the 2003-07 boom...

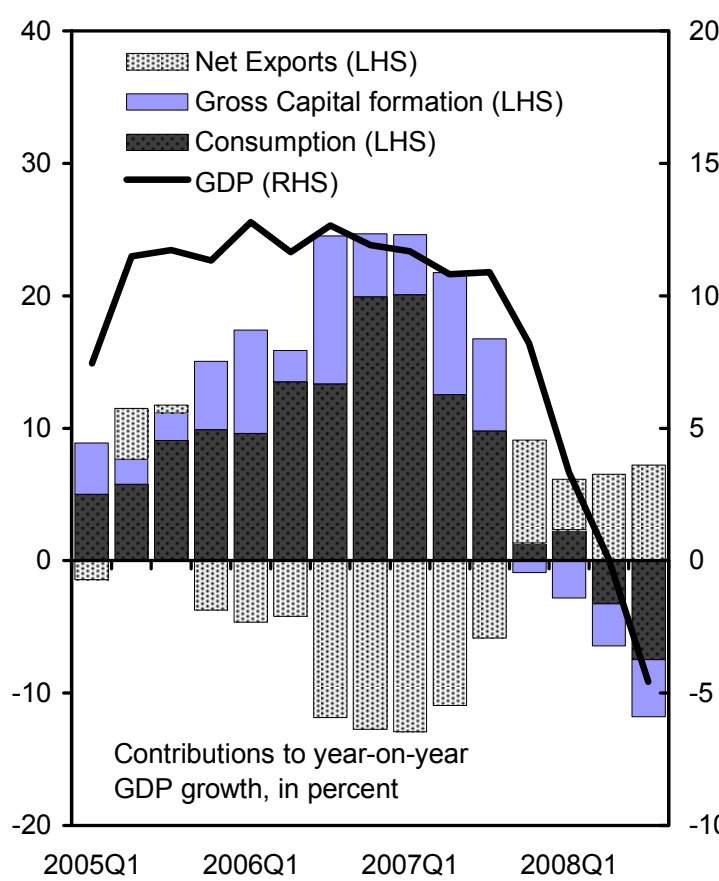

Consumer spending, particularly for durables, has collapsed

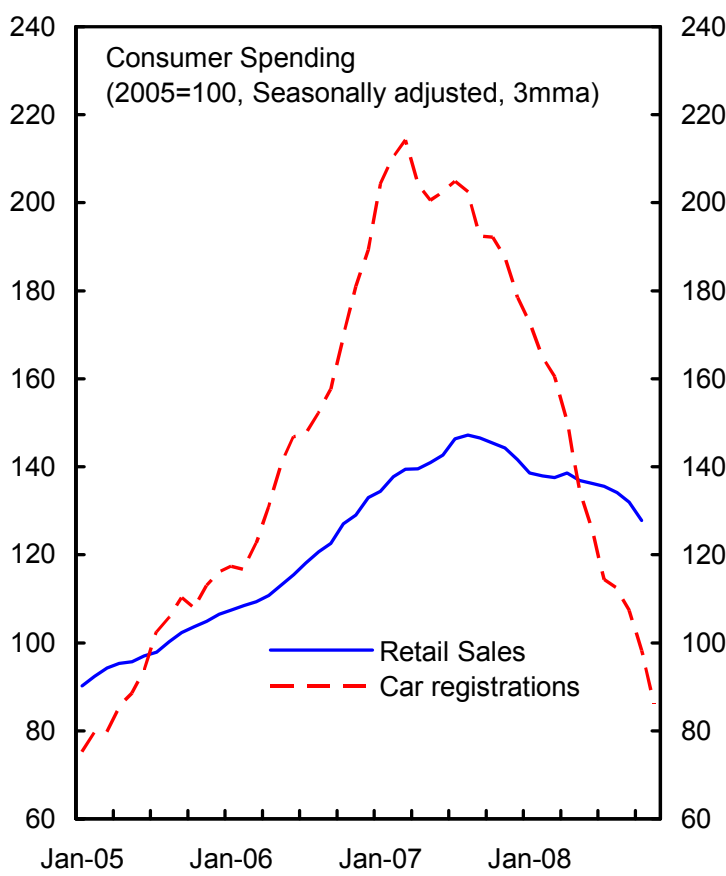

...but since early 2008 the economy has been in recession

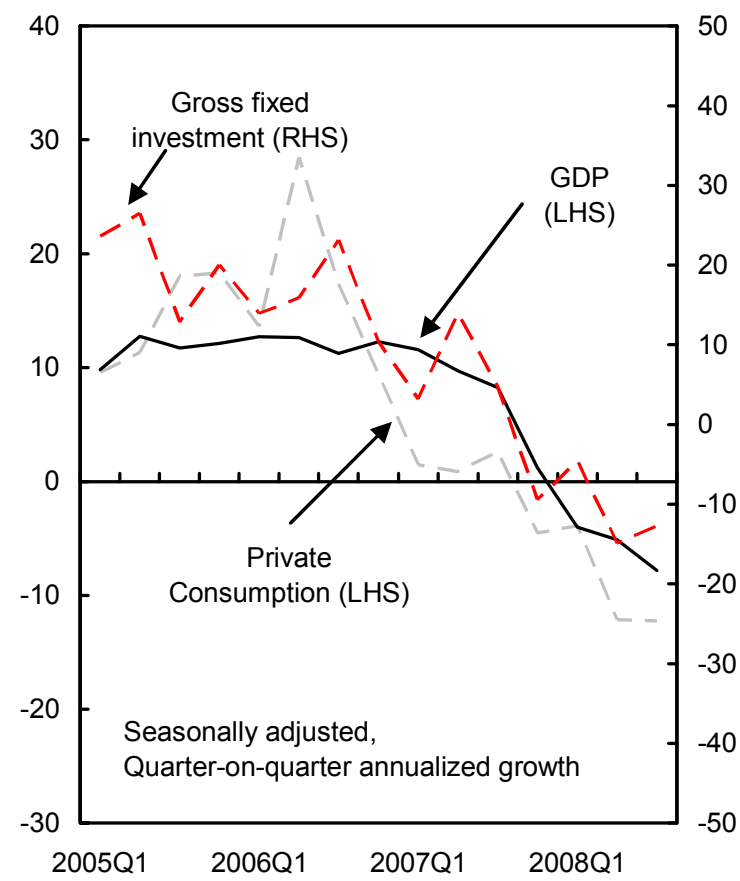

Real estate activity has collapsed, but tradables has not filled the gap

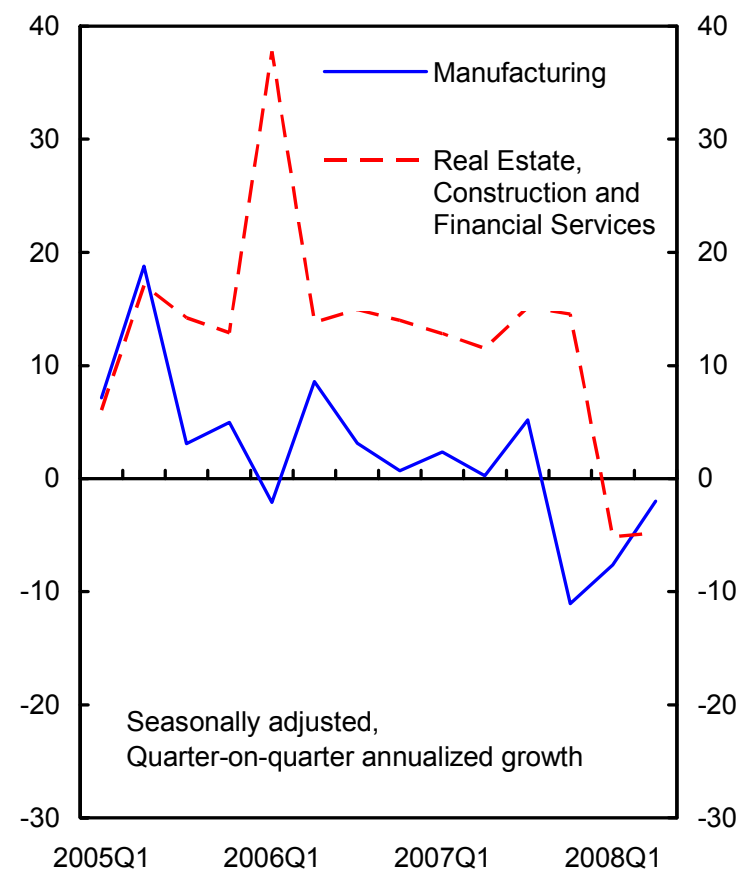

Sources: Latvian Central Statistical Bureau, Haver, Fund Staff Calculations. 
Figure 3. Latvia: Price and Wage Inflation, 2005-08

Core and headline inflation rates are falling..

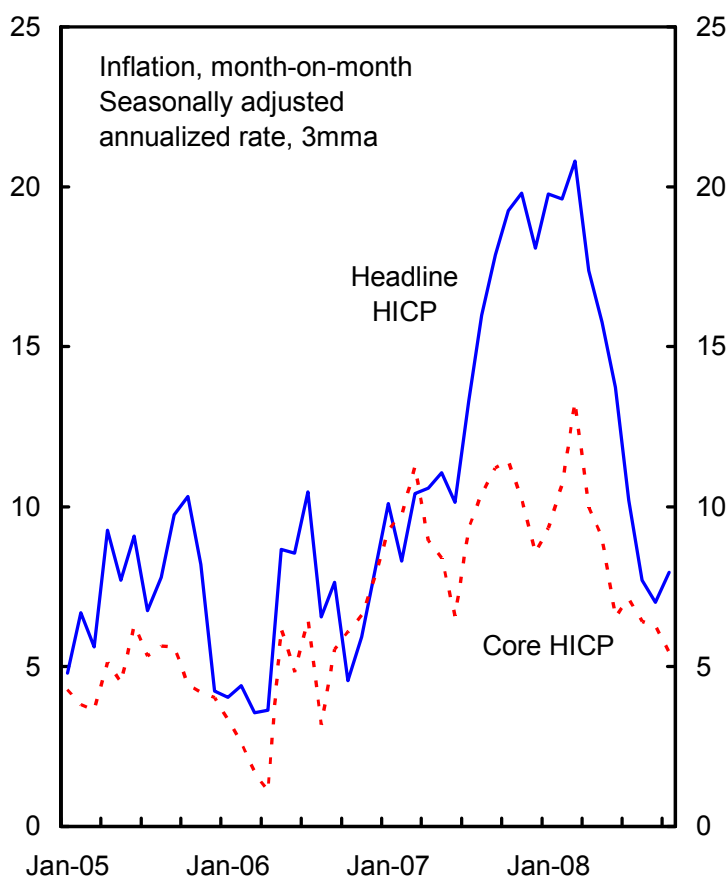

Wages are decelerating...

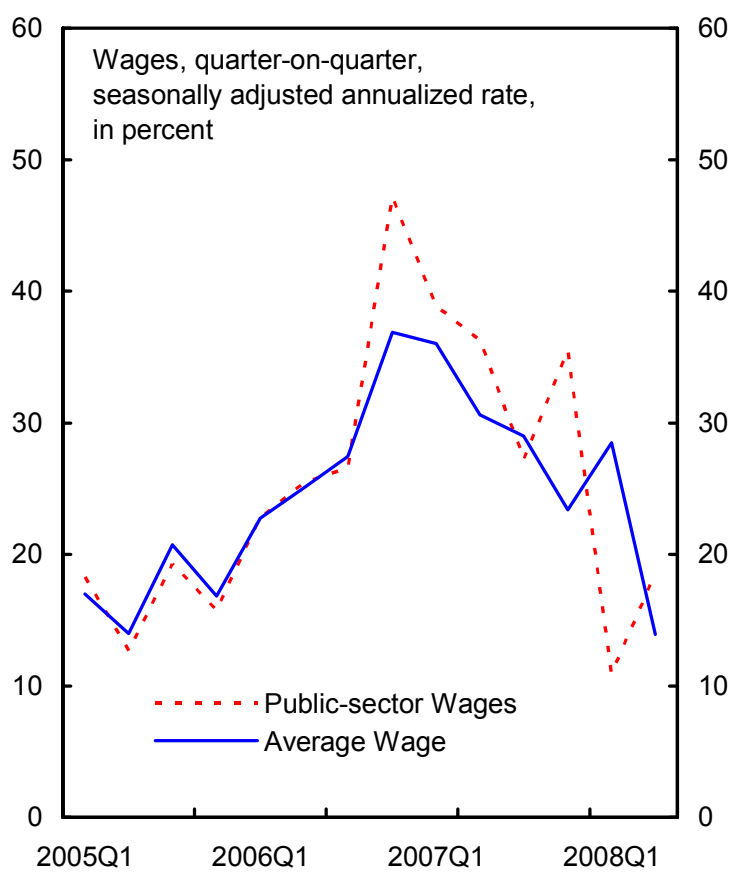

...as energy and food price inflation have subsided

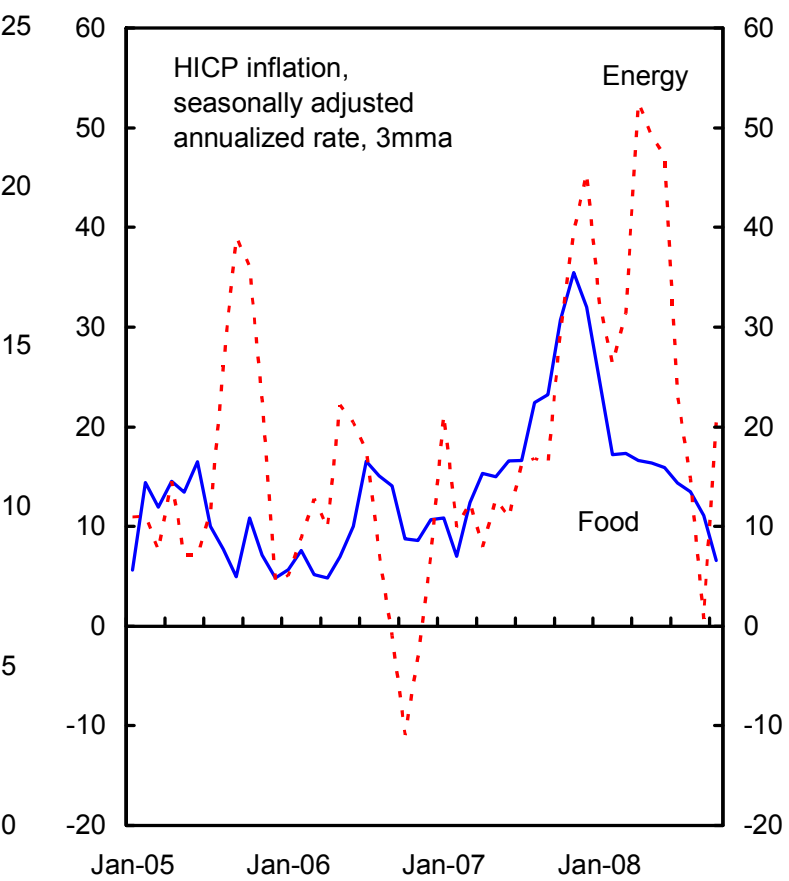

...but unit labor costs are still rising

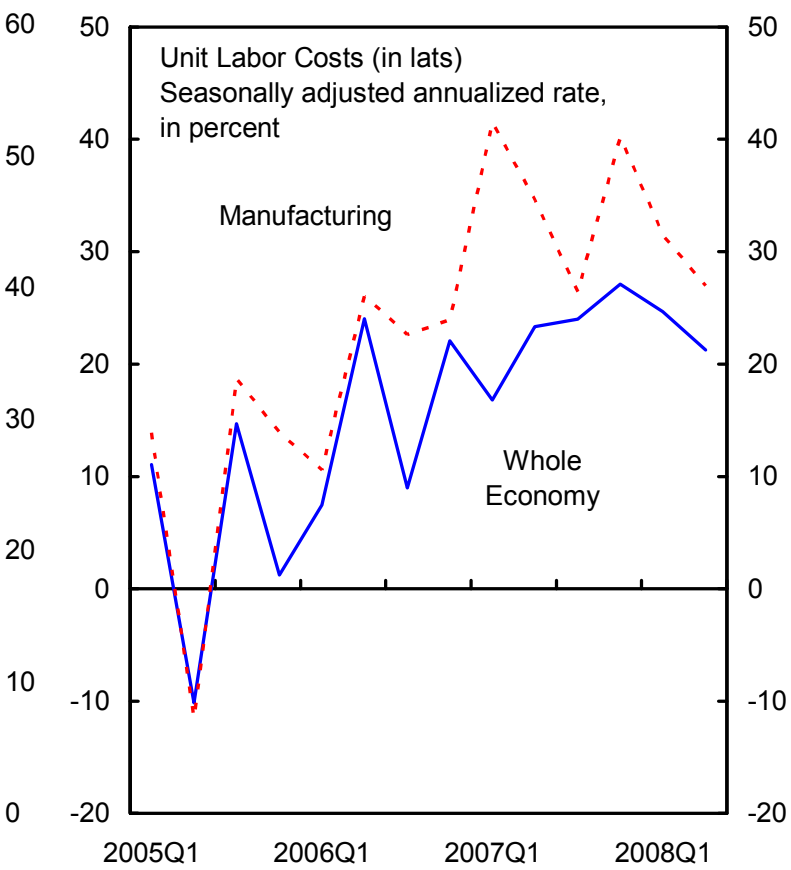

Source: Haver, Eurostat, Latvian Central Statistical Bureau, Fund Staff Calculations. 
Figure 4. Latvia: Bank Lending and Deposits, 2005-08

Credit growth has fallen sharply

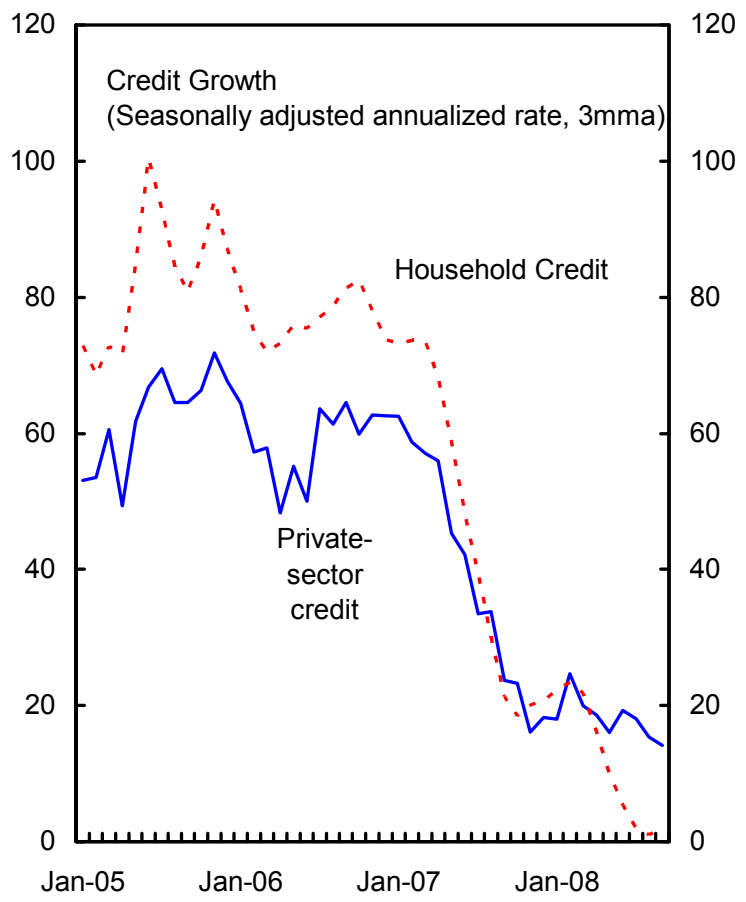

Lending is overwhelmingly in FX

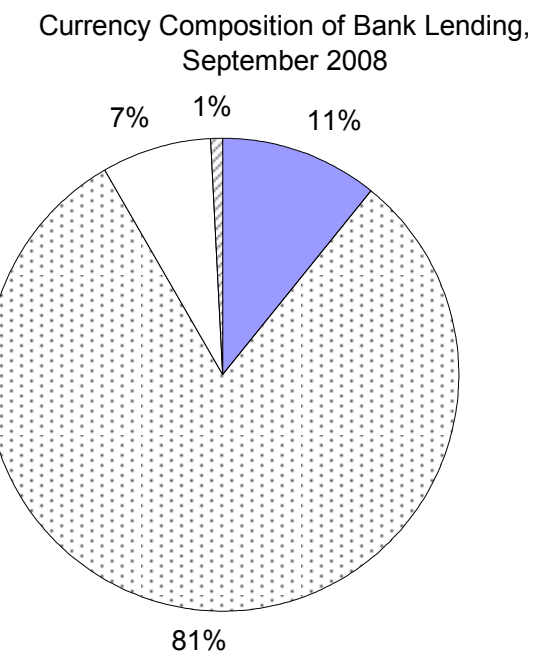

$\square$ Lats $\boxminus$ Euros $\square$ US dollar $\square$ Others
The loan stock is heavily weighted towards real estate

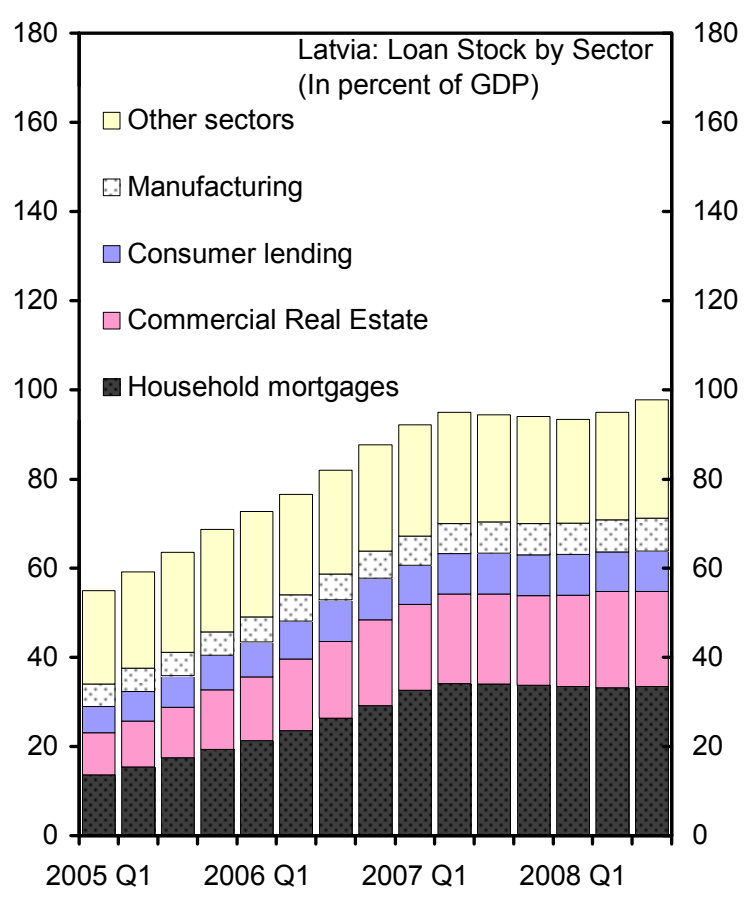

Deposit growth has stalled, especially for non-residents

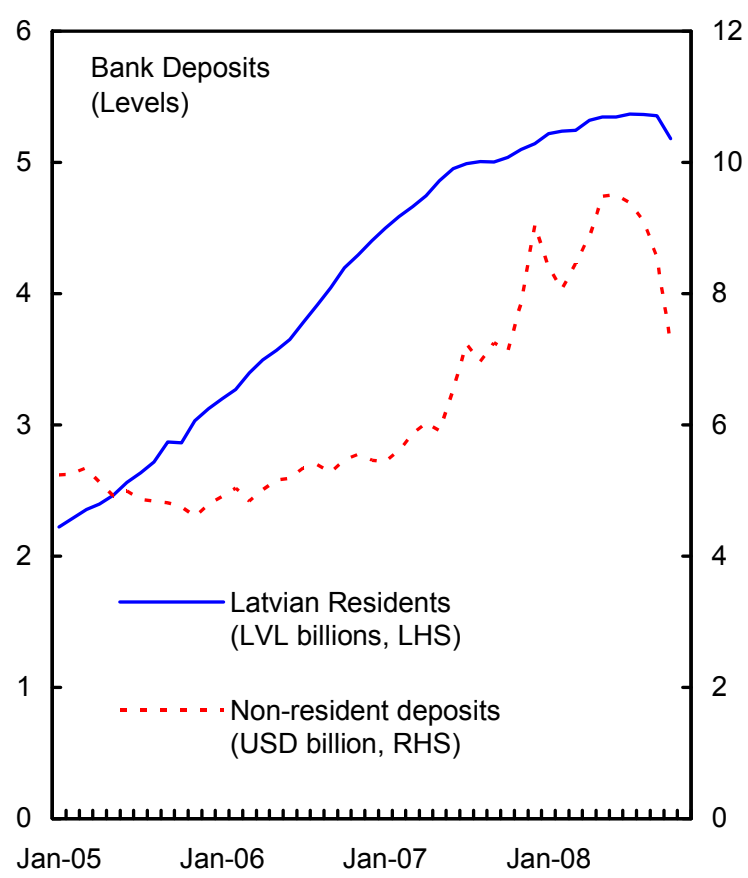

Source: Latvian Authorities, Fund Staff Calculations. 
Figure 5. Latvia: Fiscal Sector, 2005-2008

The fiscal position has deteriorated in $2008 \ldots$

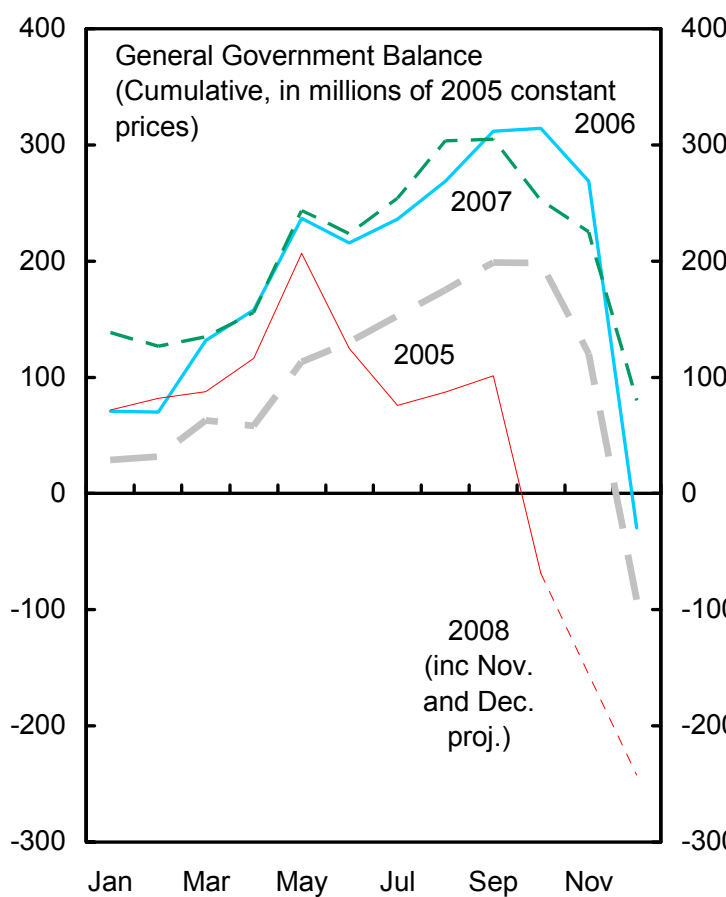

...particularly VAT

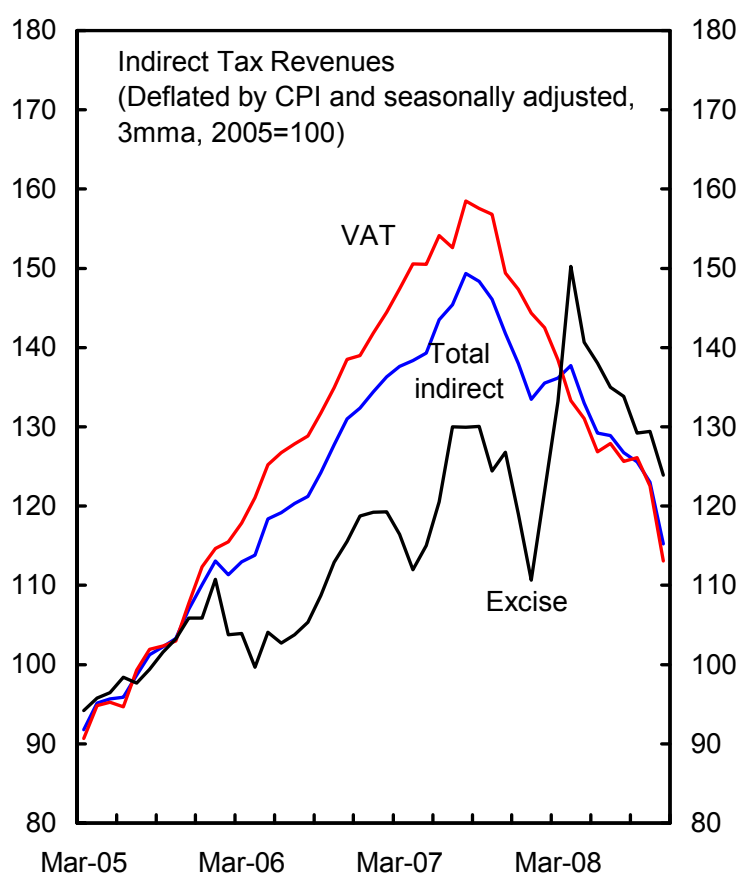

...due to a sharp fall off in indirect taxes...

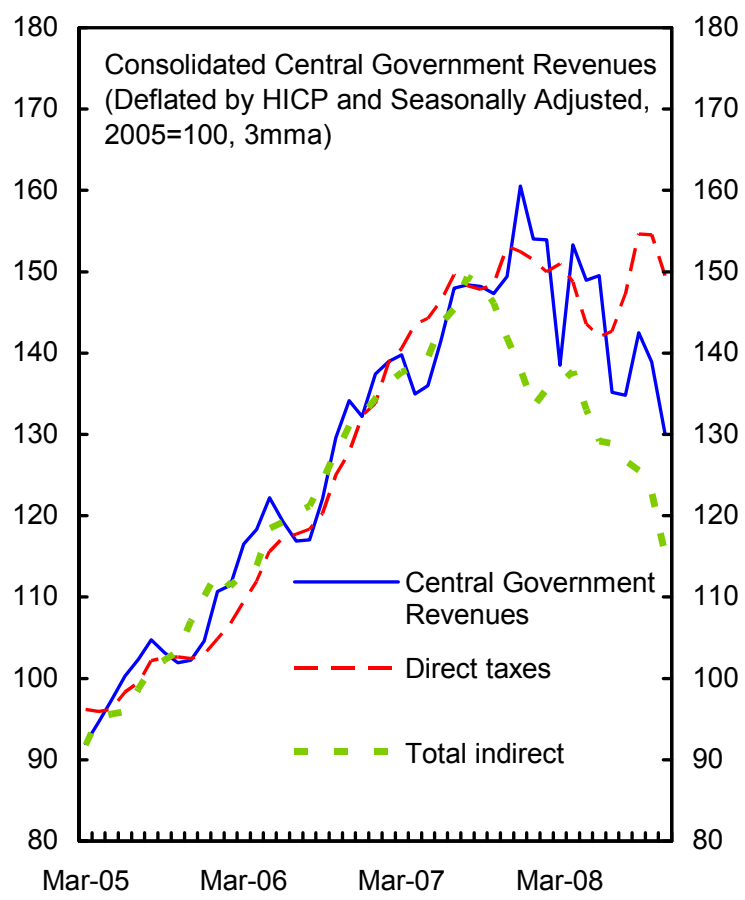

Expenditure execution exceeds the pattern of previous years

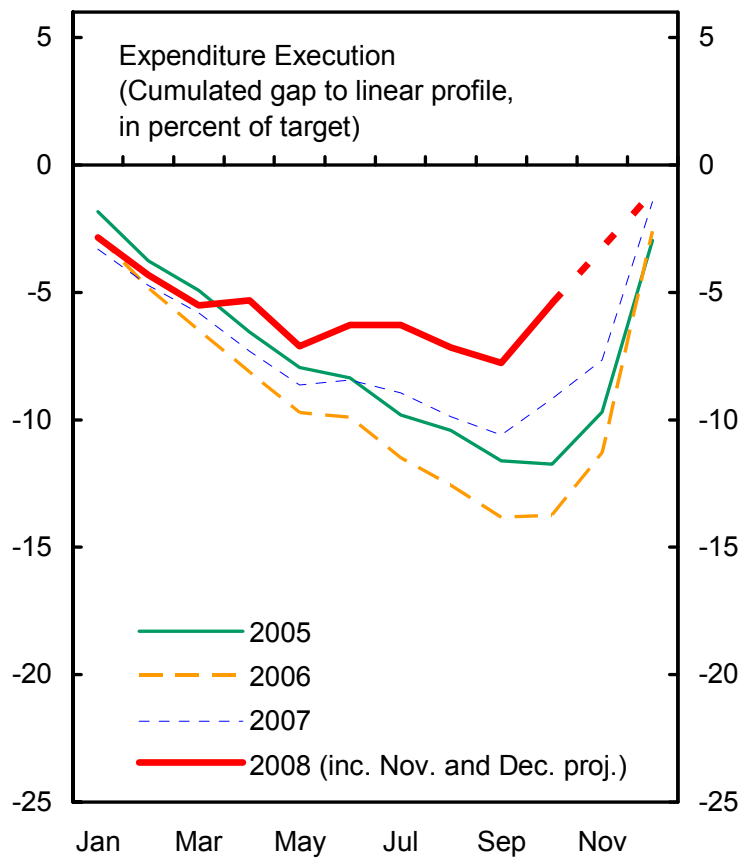

Sources: Latvian Authorities, Fund Staff Estimates and Calculations. 
Figure 6. Latvia: External developments

The current account deficit has narrowed sharply...

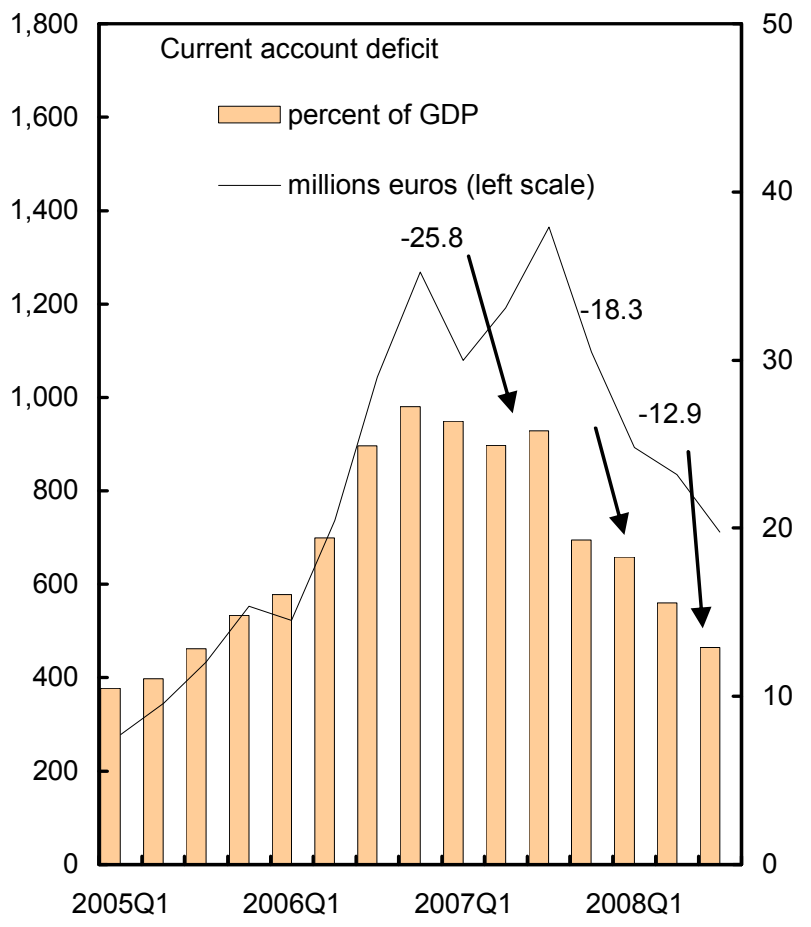

External debt has risen sharply, but is mostly long term

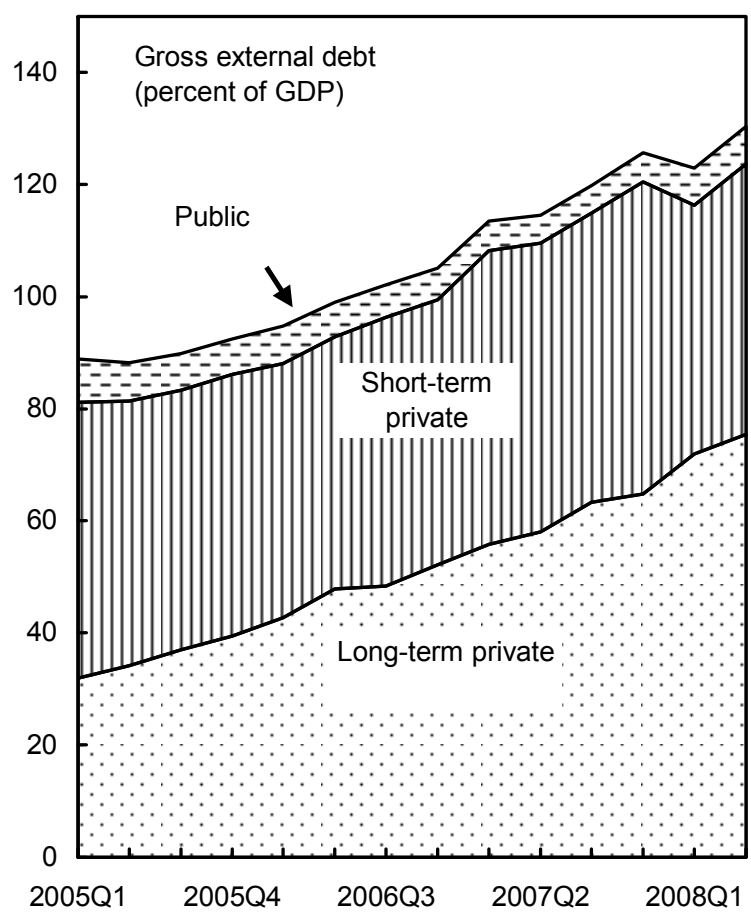

Source: BoL and IMF Staff estimates. ...despite deteriorating price and cost competitiveness

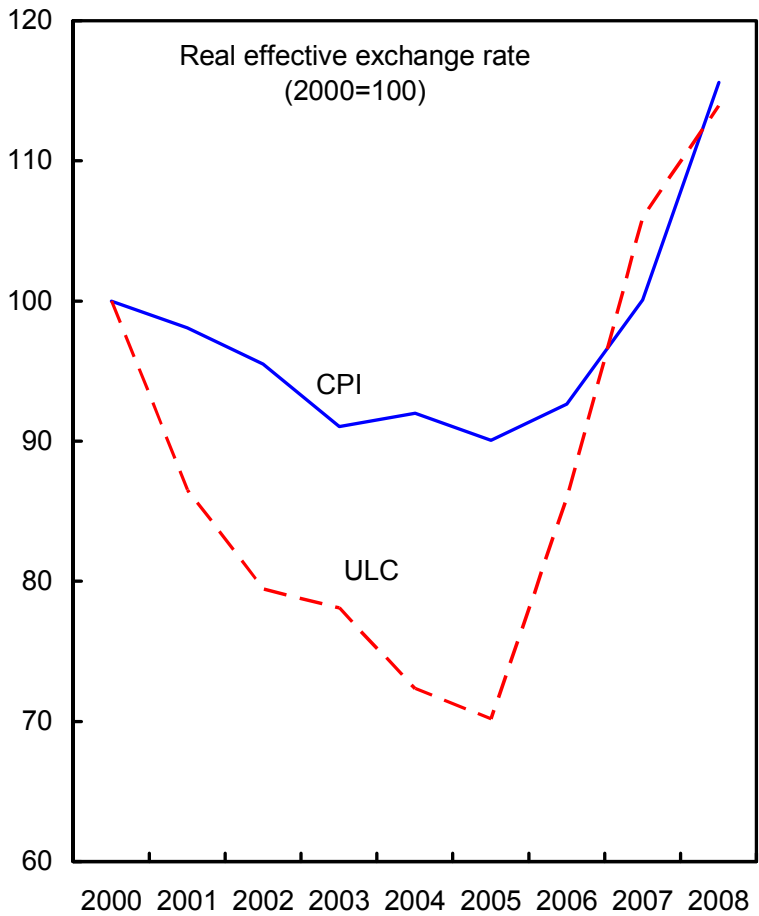

...but short-term debt remains substantial

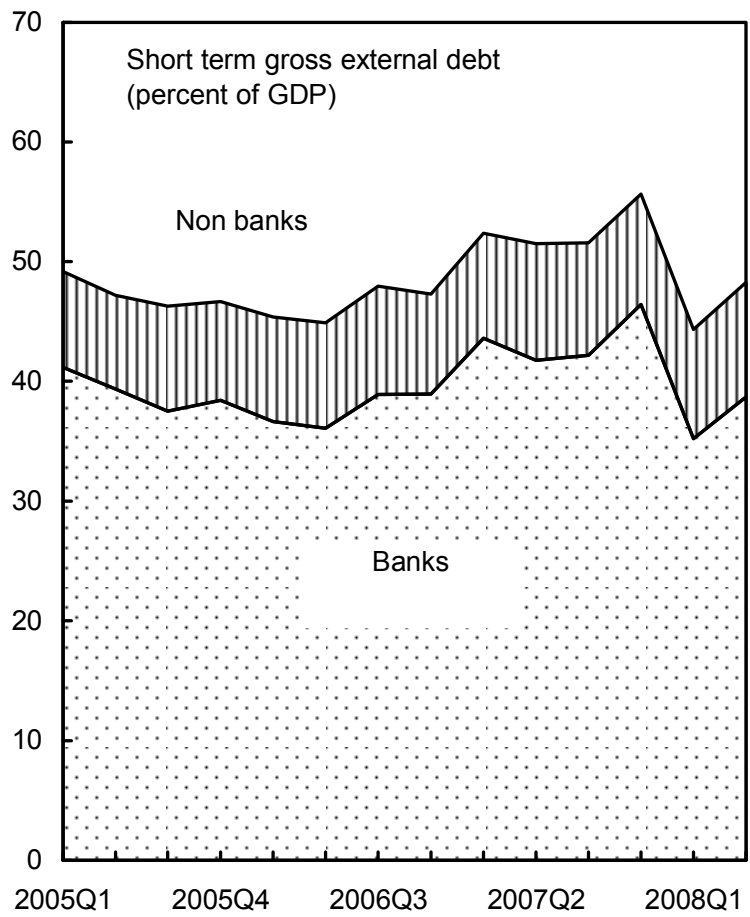


Figure 7. Banking Sector Solvency and Liquidity, 2005-08

Latvian banks may appear to be well capitalized....

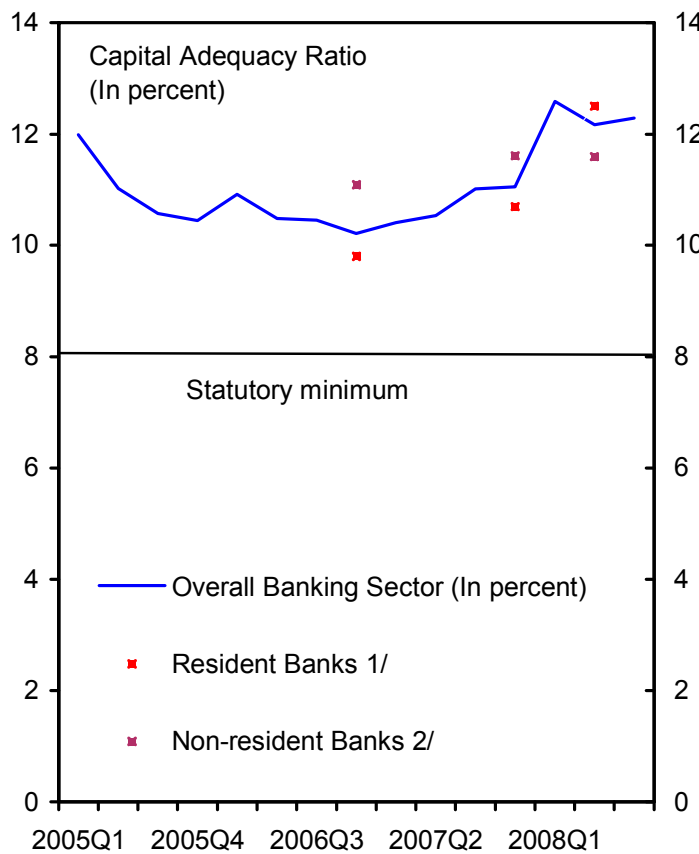

Most of the mortgages were issued at the peak of real estate prices

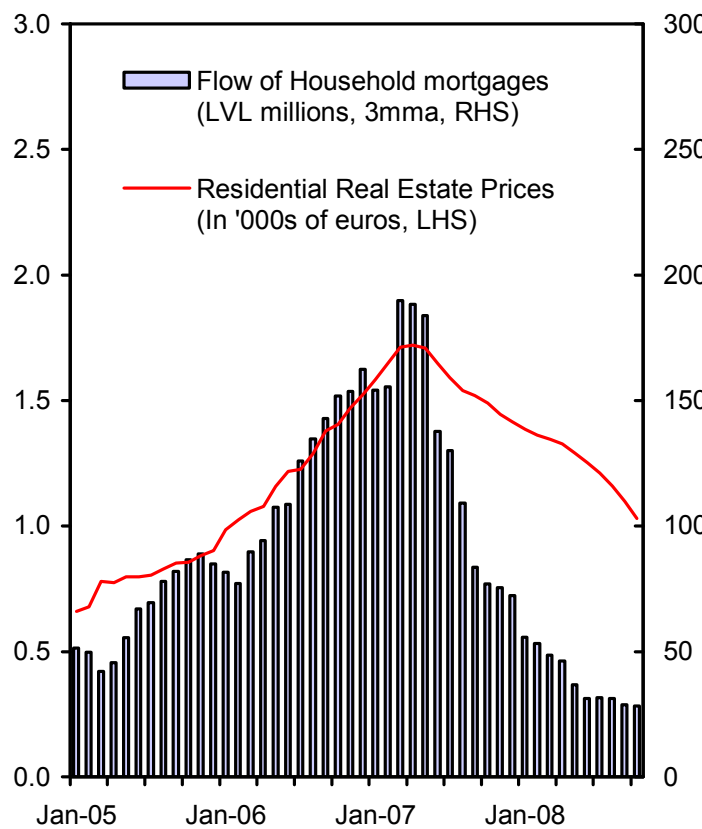

...but rising overdue loans will strain their capital buffers

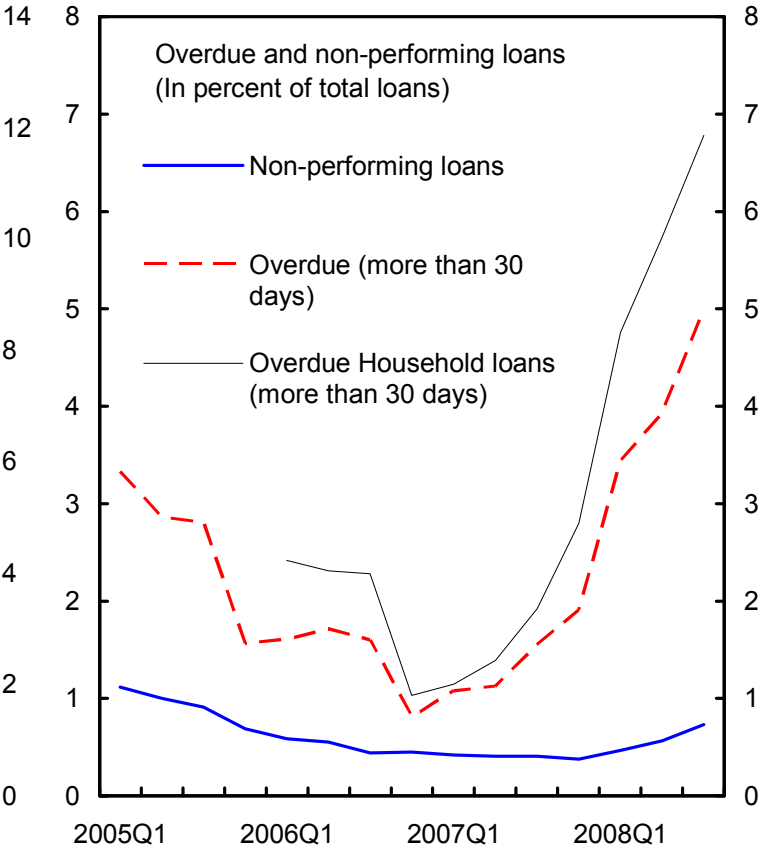

In spite of strong reported ratios, many banks face severe liquidity strains

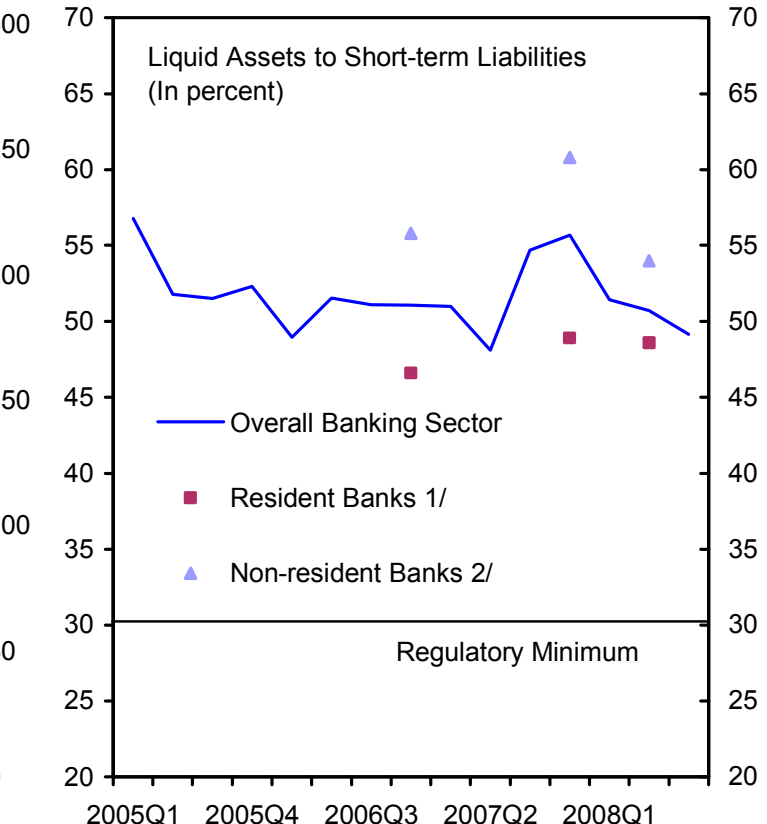

Sources: FCMC, Bank of Latvia, Latio, Arco, Oberhaus and Fund Staff Calculations.

1/ Banks dealing primarily with Latvian residents.

2/ Banks dealing primarily with non-residents of Latvia. 
Figure 8. Structure of the Banking System, 2005-08

Swedish banks have cut back lending sharply

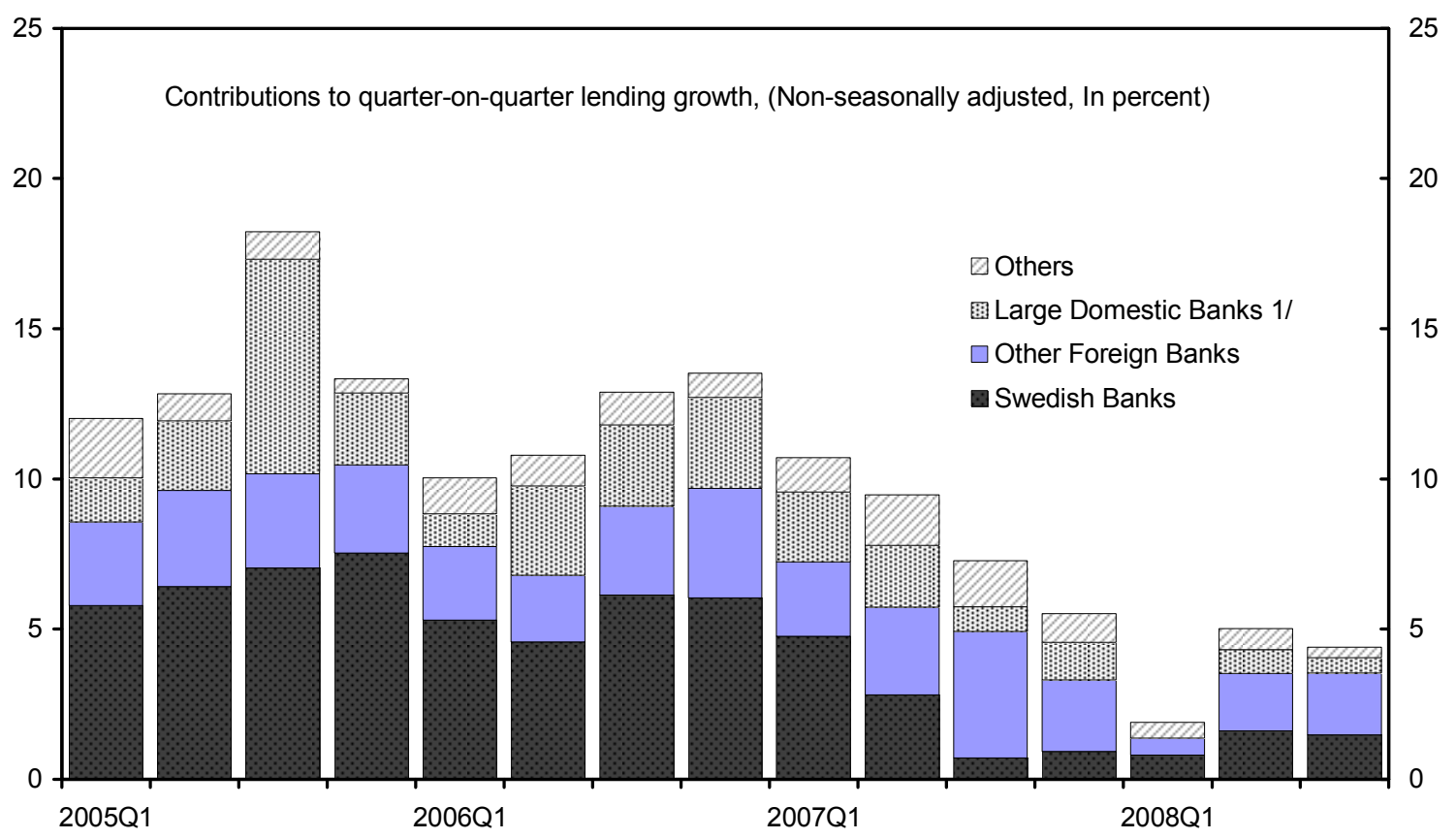

Whereas loans account for a large share of foreign banks' portfolios, a sizable share of local banks' assets are in securities or deposited abroad

Foreign Banks

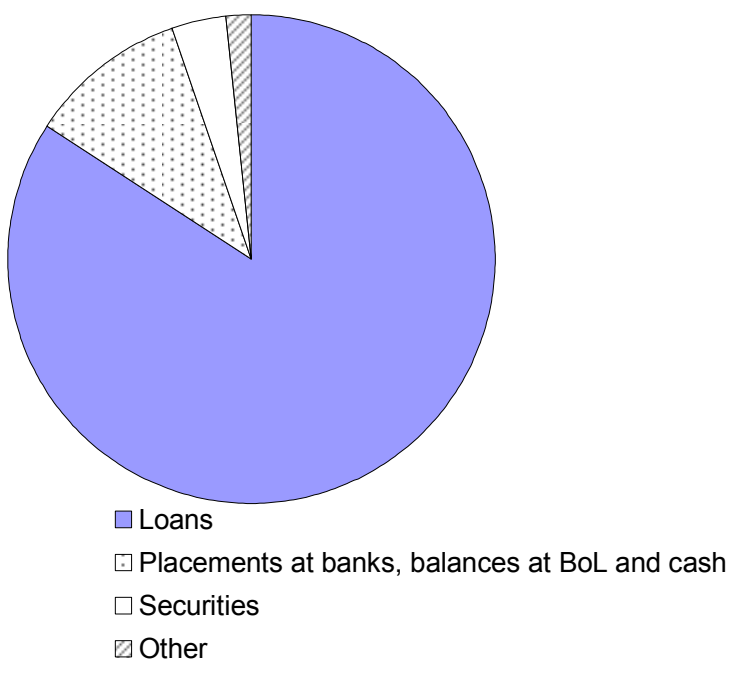

Local Banks

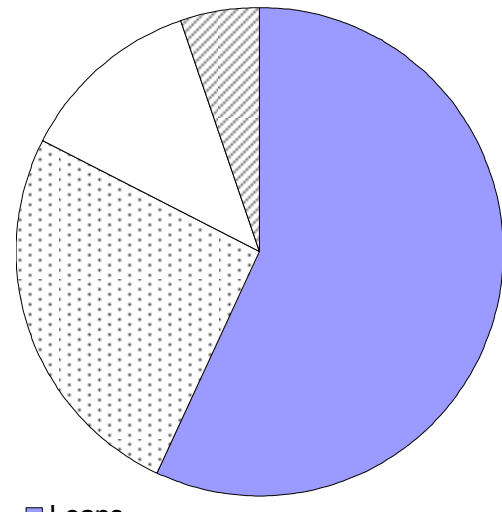

$\square$ Loans

Placements at banks, balances at BoL and cash $\square$ Securities

๑ Other

Source: Latvian Association of Commercial Banks, FCMC, Fund Staff Calculations. 
Figure 9. Financial Market Developments, 2007-08

Eurobond spreads and the Latvia CDS have reached record levels.
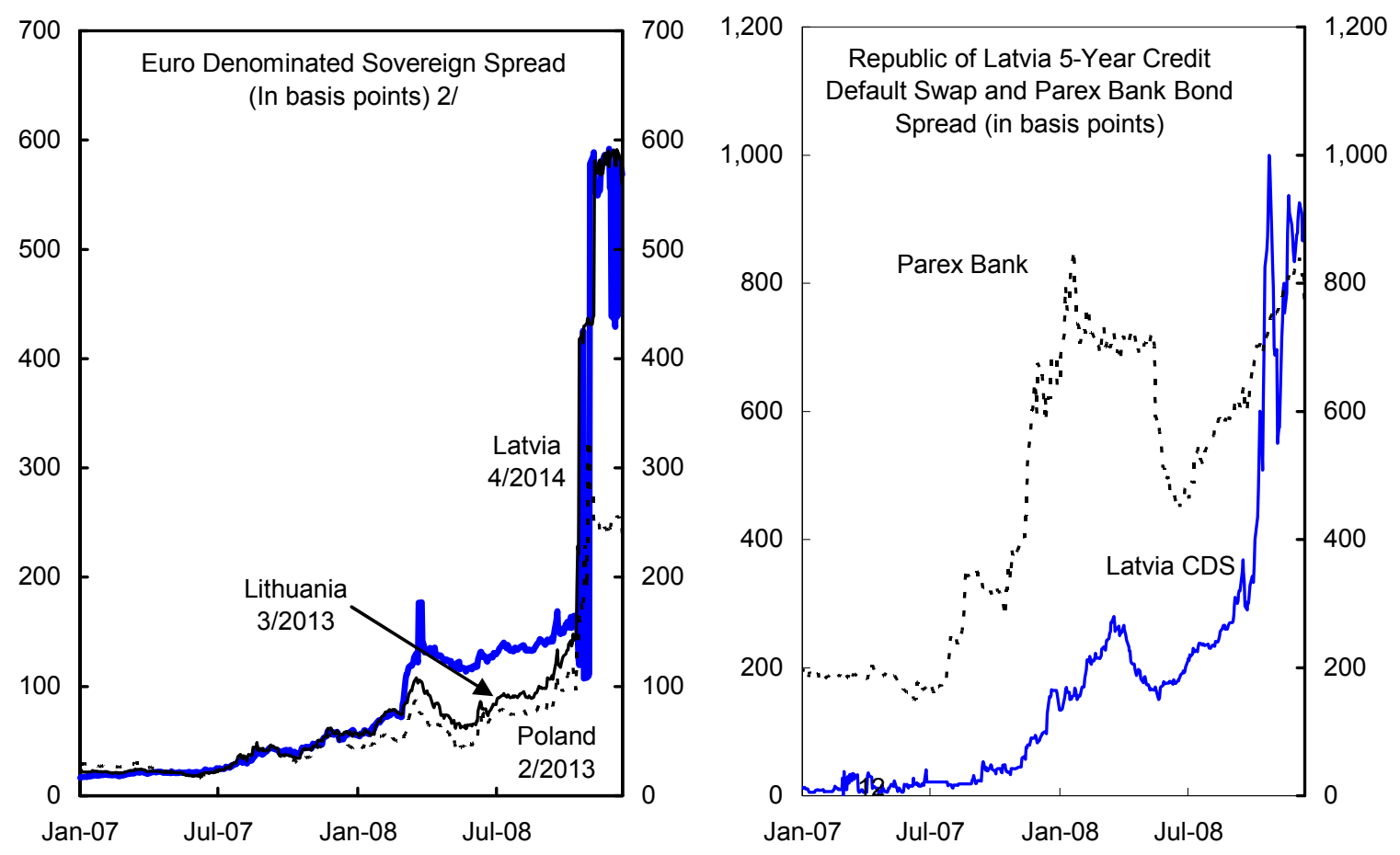

Concerns about risks in the Baltics have led to a sustained sell-off in Swedish bank shares.
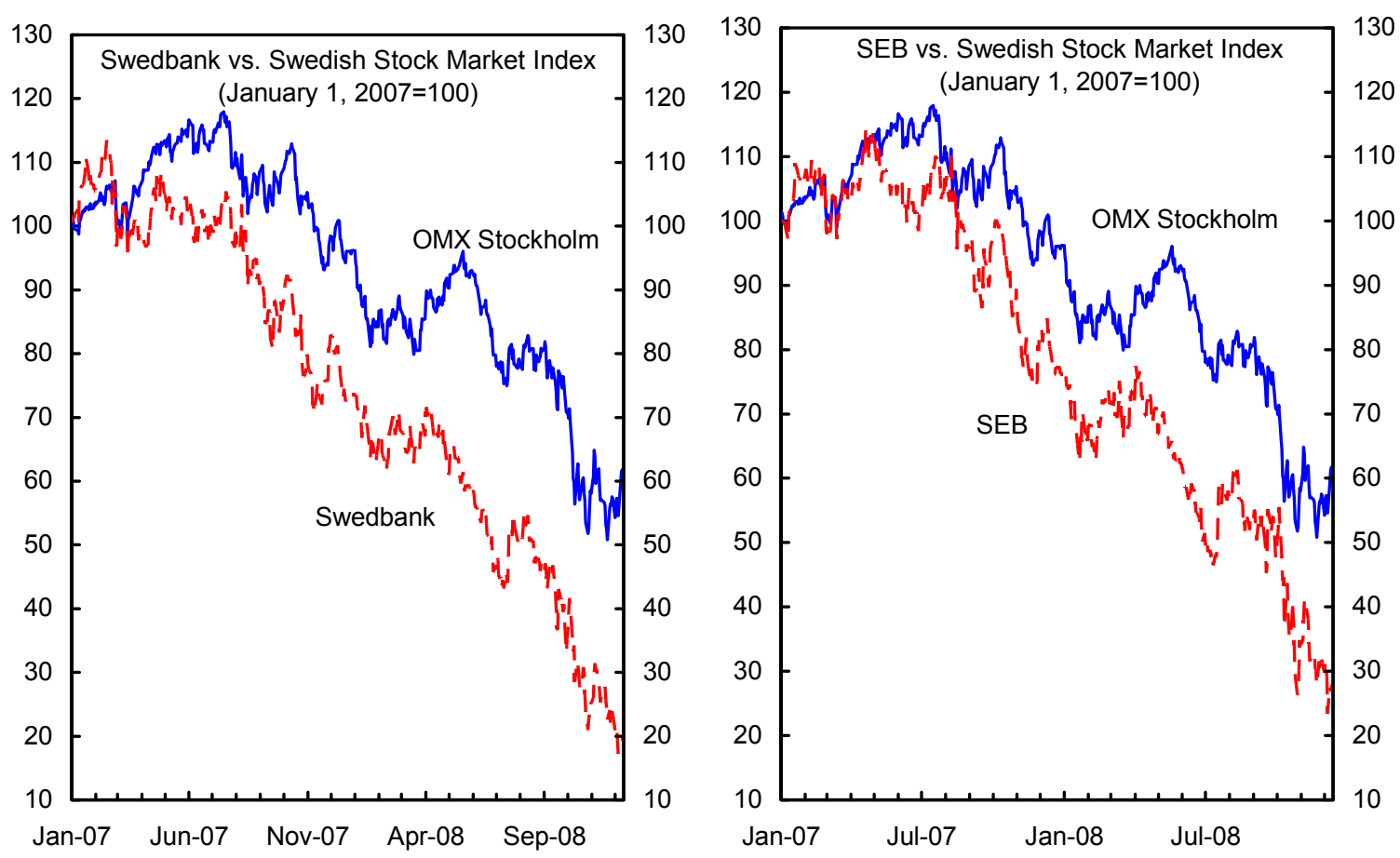

Source: Bloomberg LLP 
Figure 10. Latvia: External Debt Sustainability: Bound Tests 1/ (External debt in percent of GDP)
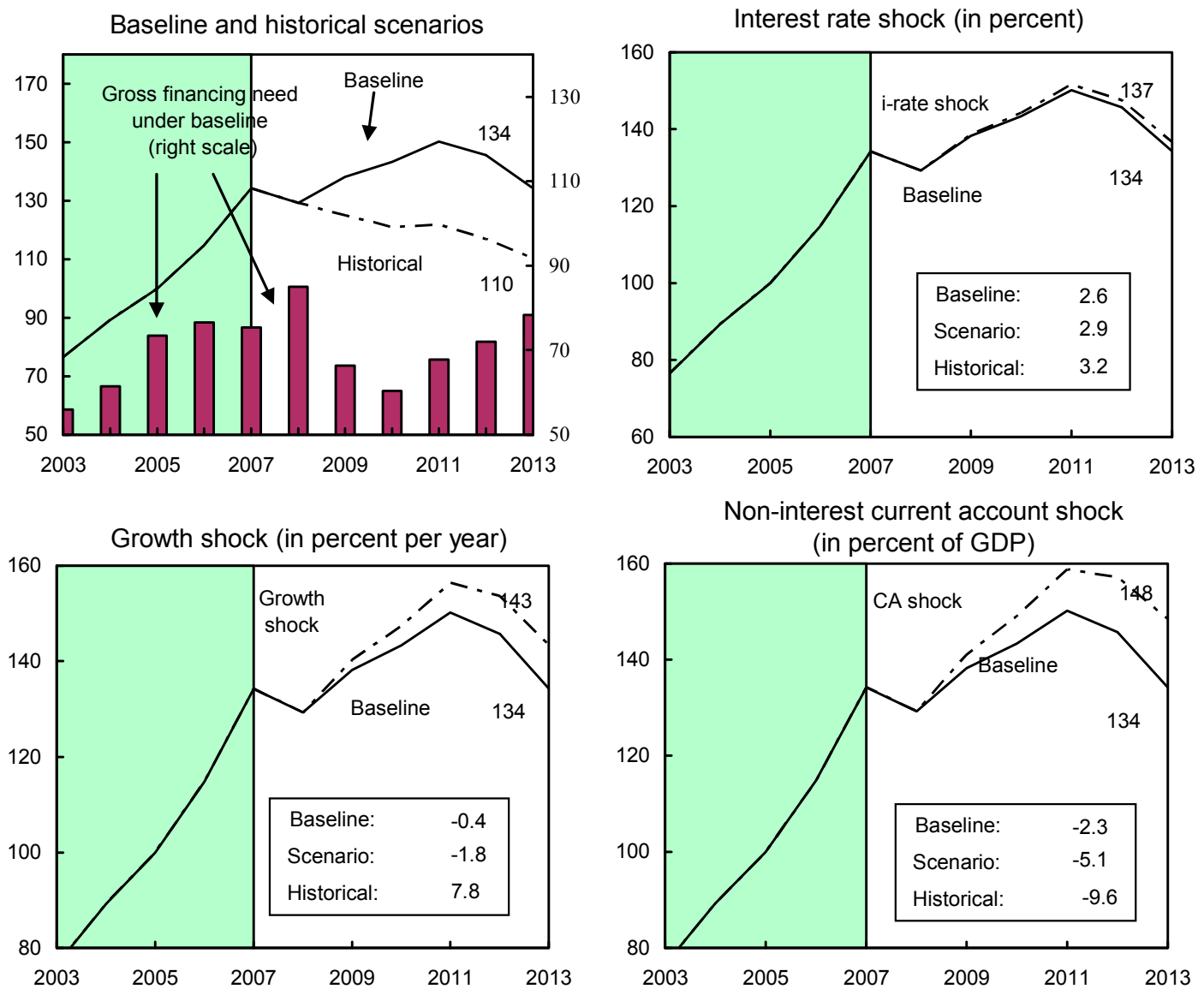

Combined shock 2/
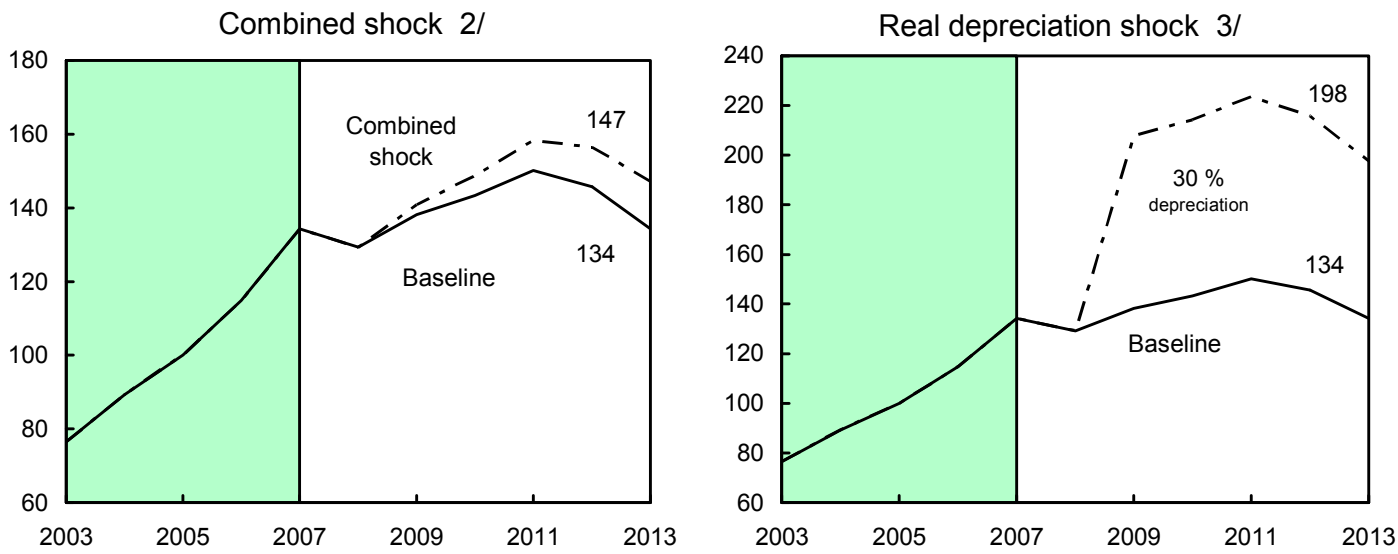

Sources: International Monetary Fund, Country desk data, and staff estimates.

1/ Shaded areas represent actual data. Individual shocks are permanent one-half standard deviation shocks.

Figures in the boxes represent average projections for the respective variables in the baseline and scenario being presented. Ten-year historical average for the variable is also shown.

$2 /$ Permanent $1 / 4$ standard deviation shocks applied to real interest rate, growth rate, and current account balance.

3/ One-time real depreciation of 30 percent occurs in 2009. 
Table 1. Latvia: Selected Economic Indicators, 2004-10

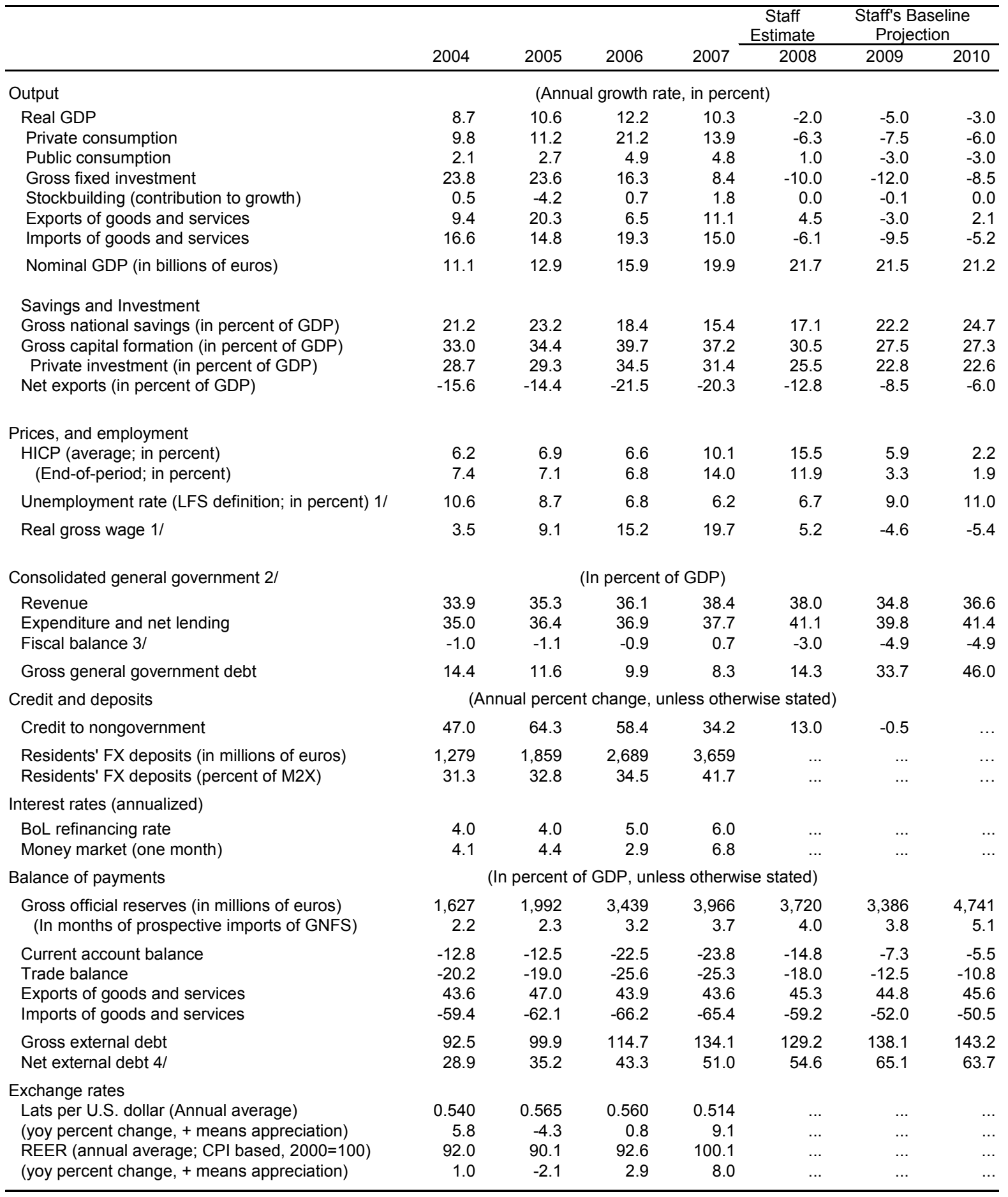

Sources: Latvian authorities; Eurostat; and IMF staff estimates.

$1 /$ Year-average.

2/ National definition. Includes economy-wide EU grants in revenue and expenditure.

3/ Basic fiscal balance excluding bank restructuring costs.

4/ Gross external debt liabilities minus gross external debt assets and international reserves. 
Table 2. General Government Operations, 2006-10 (in millions of lats)

\begin{tabular}{|c|c|c|c|c|c|c|c|c|}
\hline & \multirow{2}{*}{$\begin{array}{l}2006 \\
\text { Est. }\end{array}$} & \multirow{2}{*}{$\begin{array}{c}2007 \\
\\
\text { Est. }\end{array}$} & \multirow{2}{*}{$\begin{array}{l}2008 \\
\\
\text { Prelim. } \\
\text { Est. }\end{array}$} & \multirow[b]{2}{*}{$\begin{array}{c}\text { Budget } \\
\text { Est. }\end{array}$} & \multicolumn{2}{|c|}{2009} & \multirow[b]{2}{*}{$\begin{array}{c}\text { Prog. } \\
\text { (Supp. } \\
\text { Budget) 5/ }\end{array}$} & \multirow{2}{*}{$\begin{array}{l}2010 \\
\\
\text { Prog. }\end{array}$} \\
\hline & & & & & $\begin{array}{c}\text { Basel. } \\
4 /\end{array}$ & Meas. & & \\
\hline Total revenue and grants & 4,029 & 5,354 & 5,806 & 6,463 & 4,881 & 377 & 5,258 & 5,448 \\
\hline Tax revenue & 3,299 & 4,367 & 4,783 & 5,295 & 3,868 & 326 & 4,194 & 4,232 \\
\hline Direct Taxes & 1,936 & 2,627 & 3,030 & 3,316 & 2,299 & -30 & 2,269 & 2,335 \\
\hline Corporate Income Tax & 254 & 400 & 504 & 565 & 242 & 0 & 242 & 287 \\
\hline Personal Income Tax & 657 & 888 & 1,020 & 1,071 & 830 & -30 & 800 & 745 \\
\hline Capital Income Tax & $\ldots$ & $\ldots$ & $\ldots$ & $\ldots$ & $\ldots$ & 0 & 0 & 39 \\
\hline Social Security Contributions & 959 & 1,265 & 1,432 & 1,609 & 1,156 & 0 & 1,156 & 1,107 \\
\hline Real Estate and Property Taxes & 66 & 74 & 74 & 71 & 71 & 0 & 71 & 158 \\
\hline Indirect Taxes & 1,363 & 1,741 & 1,753 & 1,979 & 1,569 & 357 & 1,926 & 1,896 \\
\hline VAT & 931 & 1,203 & 1,135 & 1,288 & 941 & 289 & 1,230 & 1,202 \\
\hline Excises & 366 & 453 & 543 & 604 & 565 & 68 & 633 & 631 \\
\hline Other indirect taxes & 66 & 85 & 75 & 87 & 63 & 0 & 63 & 63 \\
\hline Non Tax, self-earnt and other revenue & 470 & 525 & 580 & 624 & 469 & 51 & 519 & 532 \\
\hline EU and miscellaneous funds & 260 & 462 & 442 & 544 & 544 & 0 & 544 & 685 \\
\hline Total expenditure $1 /$ & 4,128 & 5,255 & 6,269 & 6,709 & 6,701 & -697 & 6,004 & 6,171 \\
\hline Current expenditure & 3,595 & 4,495 & 5,548 & 5,991 & 5,983 & -693 & 5,290 & 5,466 \\
\hline Primary Current Expenditure & 3,532 & 4,443 & 5,455 & 5,832 & 5,805 & -693 & 5,112 & 5,108 \\
\hline Remuneration & $\ldots$ & $\ldots$ & $\ldots$ & 1,476 & 1,449 & -156 & 1,293 & 1,228 \\
\hline Wages and Salaries & 789 & 1,060 & 1,248 & 1,039 & 1,039 & -156 & 884 & 819 \\
\hline Goods and Services & $\ldots$ & 754 & 943 & 802 & 802 & -186 & 616 & 630 \\
\hline Subsidies and Grants & 1,849 & 2,101 & 2,723 & 3,357 & 3,357 & -318 & 3,039 & 3,086 \\
\hline Subsidies to companies and institutions & 733 & 933 & 1,268 & 1,710 & 1,710 & -216 & 1,494 & 1,527 \\
\hline E.U. funds related subsidies & $\ldots$ & & $\ldots$ & 583 & 583 & 0 & 583 & 711 \\
\hline Social Support & 898 & 1,087 & 1,333 & 1,525 & 1,525 & 4 & 1,529 & 1,542 \\
\hline Pensions & 667 & 760 & 897 & 1,102 & 1,102 & -30 & 1,072 & 1,096 \\
\hline Other & 231 & 327 & 436 & 423 & 423 & 34 & 457 & 446 \\
\hline Other Subsidies and Grants & 218 & 81 & 122 & 123 & 123 & -106 & 16 & 17 \\
\hline Payments to EU budget & 107 & 139 & 153 & 197 & 151 & 0 & 151 & 149 \\
\hline Other current expenditure & $\ldots$ & 390 & 388 & 0 & 46 & -33 & 13 & 15 \\
\hline Interest & 63 & 52 & 93 & 159 & 178 & 0 & 178 & 358 \\
\hline Capital expenditure & 533 & 760 & 722 & 718 & 718 & -4 & 714 & 705 \\
\hline E.U. funds related capital expenditure & $\ldots$ & $\ldots$ & $\ldots$ & 200 & 222 & 0 & 222 & 242 \\
\hline Basic fiscal balance $2 /$ & -99 & 99 & -464 & -247 & $-1,820$ & 1,074 & -746 & -723 \\
\hline Bank restructuring costs $1 /$ & 0 & 0 & 356 & 0 & 1,868 & 0 & 1,868 & 253 \\
\hline Fiscal balance & -99 & 99 & -820 & -247 & $-3,689$ & 1,074 & $-2,614$ & -977 \\
\hline Financing (net) & 99 & -99 & 820 & 247 & 3,689 & $-1,074$ & 2,614 & 977 \\
\hline Domestic financing & $\ldots$ & $\ldots$ & 286 & 247 & -97 & -183 & -280 & -911 \\
\hline External financing & $\ldots$ & $\ldots$ & 534 & $\ldots$ & 152 & 2,742 & 2,894 & 1,887 \\
\hline Financing gap & $\ldots$ & $\ldots$ & 0 & 0 & 3,633 & $-3,633$ & 0 & 0 \\
\hline \multicolumn{9}{|l|}{ Memorandum items } \\
\hline EU project financing & 260 & 462 & 430 & $\ldots$ & 536 & $\ldots$ & 536 & 685 \\
\hline Adjusted fiscal balance (cumulated from January 1) $3 /$ & -358 & -362 & -894 & $\ldots$ & $-2,356$ & $\ldots$ & $-1,282$ & $-1,408$ \\
\hline
\end{tabular}


Table 2. General Government Operations, 2006-10 (concluded) (in percent of GDP, unless otherwise indicated)

\begin{tabular}{|c|c|c|c|c|c|c|c|c|}
\hline & 2006 & 2007 & 2008 & & & & & 2010 \\
\hline & Est. & Est. & $\begin{array}{c}\text { Prelim. } \\
\text { Est. }\end{array}$ & $\begin{array}{c}\text { Budget } \\
\text { Est. }\end{array}$ & $\begin{array}{c}\text { Basel. } \\
4 /\end{array}$ & Meas. & $\begin{array}{c}\text { Prog. } \\
\text { (Supp. } \\
\text { Budget) 5/ }\end{array}$ & Prog. \\
\hline Total revenue and grants & 36.1 & 38.4 & 38.0 & 39.3 & 32.3 & +2.5 & 34.8 & 36.6 \\
\hline Tax revenue & 29.5 & 31.3 & 31.3 & 32.2 & 25.6 & +2.2 & 27.8 & 28.4 \\
\hline Direct Taxes & 17.3 & 18.8 & 19.8 & 20.1 & 15.2 & -0.2 & 15.0 & 15.7 \\
\hline Corporate Income Tax & 2.3 & 2.9 & 3.3 & 3.4 & 1.6 & $\ldots$ & 1.6 & 1.9 \\
\hline Personal Income Tax & 5.9 & 6.4 & 6.7 & 6.5 & 5.5 & -0.2 & 5.3 & 5.0 \\
\hline Capital Income Tax & $\ldots$ & $\ldots$ & $\ldots$ & $\ldots$ & $\ldots$ & $\ldots$ & 0.0 & 0.3 \\
\hline Social Security Contributions & 8.6 & 9.1 & 9.4 & 9.8 & 7.7 & $\ldots$ & 7.7 & 7.4 \\
\hline Real Estate and Property Taxes & 0.6 & 0.5 & 0.5 & 0.4 & 0.5 & $\ldots$ & 0.5 & 1.1 \\
\hline Indirect Taxes & 12.2 & 12.5 & 11.5 & 12.0 & 10.4 & +2.4 & 12.8 & 12.7 \\
\hline VAT & 8.3 & 8.6 & 7.4 & 7.8 & 6.2 & +1.9 & 8.1 & 8.1 \\
\hline Excises & 3.3 & 3.2 & 3.6 & 3.7 & 3.7 & +0.5 & 4.2 & 4.2 \\
\hline Other indirect taxes & 0.6 & 0.6 & 0.5 & 0.5 & 0.4 & $\ldots$ & 0.4 & 0.4 \\
\hline Non Tax, self-earnt and other revenue & 4.2 & 3.8 & 3.8 & 3.8 & 3.1 & +0.3 & 3.4 & 3.6 \\
\hline EU and miscellaneous funds & 2.3 & 3.3 & 2.9 & 3.3 & 3.6 & $\ldots$ & 3.6 & 4.6 \\
\hline Total expenditure $1 /$ & 36.9 & 37.7 & 41.1 & 40.7 & 44.4 & -4.6 & 39.8 & 41.4 \\
\hline Current expenditure & 32.2 & 32.2 & 36.3 & 36.4 & 39.6 & -4.6 & 35.1 & 36.7 \\
\hline Primary Current Expenditure & 31.6 & 31.8 & 35.7 & 35.4 & 38.5 & -4.6 & 33.9 & 34.3 \\
\hline Remuneration & $\ldots$ & $\ldots$ & $\ldots$ & 9.0 & 9.6 & -1.0 & 8.6 & 8.2 \\
\hline Wages and Salaries & 7.1 & 7.6 & 8.2 & 6.3 & 6.9 & -1.0 & 5.9 & 5.5 \\
\hline Goods and Services & $\ldots$ & 5.4 & 6.2 & 4.9 & 5.3 & -1.2 & 4.1 & 4.2 \\
\hline Subsidies and Grants & 16.6 & 15.1 & 17.8 & 20.4 & 22.2 & -2.1 & 20.1 & 20.7 \\
\hline Subsidies to companies and institutions & 6.6 & 6.7 & 8.3 & 10.4 & 11.3 & -1.4 & 9.9 & 10.3 \\
\hline Social Support & 8.0 & 7.8 & 8.7 & 9.3 & 10.1 & +0.0 & 10.1 & 10.3 \\
\hline Pensions & 6.0 & 5.4 & 5.9 & 6.7 & 7.3 & -0.2 & 7.1 & 7.4 \\
\hline Other & 2.1 & 2.3 & 2.9 & 2.6 & 2.8 & +0.2 & 3.0 & 3.0 \\
\hline Other Subsidies and Grants & 1.9 & 0.6 & 0.8 & 0.7 & 0.8 & -0.7 & 0.1 & 0.1 \\
\hline Payments to EU budget & 1.0 & 1.0 & 1.0 & 1.2 & 1.0 & ... & 1.0 & 1.0 \\
\hline Other current expenditure & $\ldots$ & 2.8 & 2.5 & 0.0 & 0.3 & -0.2 & 0.1 & 0.1 \\
\hline Interest & 0.6 & 0.4 & 0.6 & 1.0 & 1.2 & $\ldots$ & 1.2 & 2.4 \\
\hline Capital expenditure & 4.8 & 5.4 & 4.7 & 4.4 & 4.8 & -0.0 & 4.7 & 4.7 \\
\hline Basic fiscal balance 2/ & -0.9 & 0.7 & -3.0 & -1.5 & -12.1 & +7.1 & -4.9 & -4.9 \\
\hline Bank restructuring costs $1 /$ & 0.0 & 0.0 & 2.3 & 0.0 & 12.4 & $\ldots$ & 12.4 & 1.7 \\
\hline Fiscal balance & -0.9 & 0.7 & -5.4 & -1.5 & -24.4 & +7.1 & -17.3 & -6.6 \\
\hline Financing (net) & 0.9 & -0.7 & 5.4 & 1.5 & 24.4 & -7.1 & 17.3 & 6.6 \\
\hline Domestic financing & $\ldots$ & $\ldots$ & 1.9 & 1.5 & -0.6 & -1.2 & -1.9 & -6.1 \\
\hline External financing & $\ldots$ & $\ldots$ & 3.5 & $\ldots$ & 1.0 & 18.2 & 19.2 & 12.7 \\
\hline Financing gap & $\ldots$ & $\ldots$ & 0.0 & 0.0 & 24.1 & -24.1 & 0.0 & 0.0 \\
\hline Memorandum items & & & & & & & & \\
\hline Nominal GDP (In millions of lats) & 11,172 & 13,957 & 15,268 & 16,466 & 15,091 & 15,091 & 15,091 & 14,898 \\
\hline Real GDP growth & 12.2 & 10.3 & -2.0 & 1.1 & -5.0 & -5.0 & -5.0 & -3.0 \\
\hline Structural adjustment (Cyclical Revenues) & -1.1 & -3.4 & -1.8 & 2.2 & 2.2 & $\ldots$ & 2.2 & 4.0 \\
\hline Structural balance & -2.0 & -2.7 & -4.8 & 0.7 & -9.8 & 7.1 & -2.7 & -0.9 \\
\hline Fiscal impulse (year on year) & 1.0 & 0.7 & 2.1 & -5.6 & 5.0 & -7.1 & -2.1 & -1.8 \\
\hline Cyclically adjusted balance & -2.0 & -2.7 & -7.1 & 0.7 & -22.2 & 7.1 & -15.1 & -2.6 \\
\hline Adjusted Basic fiscal balance 3/ & -3.2 & -2.6 & -5.9 & $\ldots$ & -15.6 & 7.1 & -8.5 & -9.5 \\
\hline General government gross debt & 9.9 & 8.3 & 14.3 & $\cdots$ & $\ldots$ & $\ldots$ & 33.7 & 46.0 \\
\hline General government contingent liabilities & $\ldots$ & $\ldots$ & 34.7 & $\ldots$ & $\ldots$ & $\ldots$ & 38.5 & 31.4 \\
\hline
\end{tabular}

Source: Latvian Authorities, Fund Staff Estimates.

1/ Total expenditure exclude Net acquisition of financial assets and other Bank restructuring costs impacting the fiscal balance: Loans to financial institutions and investments in equity of financial institutions (requited recapitalization); unrequited recapitalization; purchase of troubled assets.

2/ Basic fiscal balance, in cash, or Net government borrowing/lending.

3/ Basic fiscal balance (cumulated from January 1) minus E.U. funds (project grants).

4/ Projected outturn under constant policy assumption, with 2009 initial budget approved on November 14, 2008. Interest expenditure estimates taken from the Program scenario.

5/ Supplementary budget approved on December 11, 2008. 
Table 3. Latvia: Selected Vulnerability Indicators, 2003-08

\begin{tabular}{|c|c|c|c|c|c|c|c|}
\hline & 2003 & 2004 & 2005 & 2006 & $2007 \quad 2$ & $20081 /$ & $\begin{array}{c}\text { Latest } \\
\text { Observation }\end{array}$ \\
\hline \multicolumn{8}{|l|}{ Key economic and market indicators } \\
\hline Real GDP growth (in percent) & 7.2 & 8.7 & 10.6 & 12.2 & 10.3 & -4.6 & Q3, 2008 \\
\hline HICP inflation (period average, in percent) & 3.3 & 6.2 & 6.9 & 6.6 & 10.1 & 13.7 & Oct-08 \\
\hline Short-term (ST) interbank rate, 1-month RIGIBOR (eop, in percent) & 4.1 & 4.1 & 4.4 & 2.9 & 6.8 & 13.9 & 15-Dec-08 \\
\hline Eurobond secondary market spread (bps, eop) & 32 & 22 & 16 & 19 & 58 & 568 & $12-D e c-08$ \\
\hline Exchange rate NC/US\$ (eop) & 0.54 & 0.52 & 0.59 & 0.54 & 0.48 & 0.54 & Nov-08 \\
\hline Exchange rate NC/US\$ (period average) & 0.57 & 0.54 & 0.56 & 0.56 & 0.51 & 0.55 & Nov-08 \\
\hline \multicolumn{8}{|l|}{ External sector } \\
\hline Exchange rate regime & \multicolumn{7}{|c|}{$\rightarrow$ Pegged to the euro $(+-1 \%$ band $)$} \\
\hline Current account balance (in percent of GDP) & -8.2 & -12.8 & -12.5 & -22.5 & -23.8 & -12.9 & Q3, 2008 \\
\hline Net FDI inflows (in percent of GDP) & 2.3 & 3.8 & 3.6 & 7.5 & 7.1 & 4.8 & Q3, 2008 \\
\hline Exports (in percentage change of US\$ value, GNFS) & 23.6 & 28.3 & 25.4 & 16.7 & 34.8 & 12.1 & Q3, 2008 \\
\hline Real effective exchange rate index $(2000=100$, period average $)$ & 91.0 & 92.0 & 90.1 & 92.6 & 100.1 & 110.7 & Oct-08 \\
\hline Gross international reserves (GIR, in US\$ billion) & 1.5 & 2.0 & 2.4 & 4.5 & 5.8 & 4.7 & Nov-08 \\
\hline GIR in percent of ST debt at remaining maturity (RM) excluding non-resident deposits & 77.6 & 84.9 & 92.6 & 66.0 & 60.7 & $\ldots$ & Q4, 2007 \\
\hline GIR in percent of ST debt at RM including banks' non-resident FX deposits. & 27.1 & 26.2 & 31.5 & 35.9 & 30.0 & & Q4, 2007 \\
\hline Net international reserves (NIR, in US\$ billion) & 1.5 & 2.0 & 2.3 & 4.4 & 5.7 & 6.5 & Nov-08 \\
\hline Total gross external debt (ED, in percent of GDP) & 79.1 & 92.5 & 99.9 & 114.7 & 134.1 & 134.0 & Q2, 2008 \\
\hline Of which: ST external debt (original maturity, in percent of total ED) & 60.7 & 57.3 & 49.3 & 44.1 & 43.2 & 35.9 & Q2, 2008 \\
\hline ED of domestic private sector (in percent of total ED) & 91.0 & 91.0 & 93.3 & 94.8 & 96.0 & 95.1 & Q2, 2008 \\
\hline Total gross external debt (in percent of exports of GNFS) & 189.4 & 214.3 & 211.5 & 259.6 & 309.5 & $\ldots$ & Q2, 2008 \\
\hline Gross external financing requirement (in US\$ billion) 2/ & 1.7 & 3.6 & 3.8 & 6.6 & 8.8 & $\cdots$ & Q4, 2007 \\
\hline \multicolumn{8}{|l|}{ Public sector (PS) 3/ } \\
\hline Overall balance (in percent of GDP) & -1.6 & -1.0 & -1.1 & -0.9 & 0.7 & 0.9 & Q1, 2008 \\
\hline Primary balance (in percent of GDP) & -0.8 & -0.3 & -0.5 & -0.3 & $1.1 \ldots$ & & Q1, 2008 \\
\hline Debt-stabilizing primary balance (in percent of GDP) 4/ & -1.0 & -1.5 & -1.7 & -1.7 & -2.0 & & Q4, 2007 \\
\hline Gross PS financing requirement (in percent of GDP) $5 /$ & 4.5 & 4.6 & 3.1 & 2.6 & 0.2 & 1.6 & Q4, 2007 \\
\hline General government gross debt (in percent of GDP) & 13.2 & 14.4 & 11.6 & 9.9 & 8.3 & 6.7 & Q4, 2007 \\
\hline \multicolumn{8}{|l|}{ Financial sector (FS) 6/ } \\
\hline Capital adequacy ratio (in percent) & 11.7 & 11.7 & 10.1 & 10.2 & 11.1 & 12.3 & Q3, 2008 \\
\hline NPLs (in percent of total loans) & 1.4 & 1.1 & 0.7 & 0.4 & 0.4 & 0.7 & Q3, 2008 \\
\hline Provisions (in percent of NPLs) & 89.4 & 99.1 & 98.8 & 116.6 & 129.8 & 119 & Q3, 2008 \\
\hline Return on average assets (in percent) & 1.4 & 1.7 & 2.1 & 2.1 & 2.0 & 1.2 & Q3, 2008 \\
\hline Return on equity (in percent) & 16.7 & 21.4 & 27.1 & 25.6 & 24.2 & 14.7 & Q3, 2008 \\
\hline FX deposits held by residents (in percent of total deposits held by residents) & 36.6 & 38.3 & 39.9 & 40.3 & 46.8 & 47.1 & Q3, 2008 \\
\hline FX loans to residents (in percent of total loans to residents) & 56.1 & 60.9 & 70.0 & 76.9 & 86.4 & 88.2 & Q2, 2008 \\
\hline Credit to private sector (percent change) $7 /$ & 37.5 & 47.0 & 64.3 & 58.4 & 34.2 & 14.3 & Nov-08 \\
\hline \multicolumn{8}{|l|}{ Memorandum item: } \\
\hline Nominal GDP in billions of U.S. dollars & 11.2 & 13.8 & 16.0 & 19.9 & 27.2 & 8.2 & Q3 2008 \\
\hline
\end{tabular}

Sources: Latvian authorities, and Fund staff calculations.

$1 /$ Latest observations as indicated in the last column.

2/ Current account deficit plus amortization of external debt.

3/ Public sector covers general government.

4/ Relevant variables for calculations - i.e., growth rates, interest rates, etc, are averaged over the last five years.

$5 /$ Overall balance plus debt amortization.

6/ Financial sector includes commercial banks.

7/ Total loans less loans to the public sector and transit loans, provided to both residents and non-residents. 
Table 4. Latvia: Medium Term Balance of Payments, 2005-13 (In millions of euros)

\begin{tabular}{|c|c|c|c|c|c|c|c|c|c|}
\hline & 2005 & 2006 & 2007 & 2008 & 2009 & 2010 & 2011 & 2012 & 2013 \\
\hline & & & & \multicolumn{6}{|c|}{ Projections } \\
\hline Current account & $-1,610$ & $-3,571$ & $-4,734$ & $-3,217$ & $-1,566$ & $-1,161$ & $-1,178$ & $-1,216$ & $-1,270$ \\
\hline Trade balance (fob) & $-2,440$ & $-4,064$ & $-5,032$ & $-3,917$ & $-2,689$ & $-2,289$ & $-2,303$ & $-2,351$ & $-2,572$ \\
\hline Exports & 4,313 & 4,883 & 5,997 & 6,741 & 6,573 & 6,609 & 6,959 & 7,412 & 7,897 \\
\hline Imports & 6,753 & 8,947 & 11,028 & 10,658 & 9,263 & 8,898 & 9,262 & 9,763 & 10,469 \\
\hline Services & 487 & 530 & 706 & 899 & 1,132 & 1,241 & 1,329 & 1,404 & 1,566 \\
\hline Credit & 1,743 & 2,101 & 2,671 & 3,093 & 3,039 & 3,056 & 3,218 & 3,395 & 3,616 \\
\hline Debit & 1,256 & 1,571 & 1,966 & 2,194 & 1,907 & 1,814 & 1,888 & 1,991 & 2,050 \\
\hline Income & -139 & -424 & -684 & -650 & -470 & -484 & -650 & -723 & -701 \\
\hline Investment income & -432 & -786 & $-1,057$ & $-1,021$ & -815 & -805 & $-1,054$ & $-1,137$ & $-1,131$ \\
\hline Compensation of employees & 293 & 362 & 373 & 371 & 345 & 321 & 404 & 414 & 430 \\
\hline Current transfers & 482 & 387 & 276 & 451 & 461 & 371 & 446 & 455 & 437 \\
\hline Capital and financial account & 2,272 & 5,039 & 5,595 & 2,198 & $-2,168$ & -84 & 1,456 & 2,564 & 3,274 \\
\hline Capital account & 170 & 191 & 410 & 317 & 415 & 615 & 677 & 744 & 819 \\
\hline Financial account (net) & 2,102 & 4,848 & 5,185 & 1,881 & $-2,583$ & -699 & 779 & 1,820 & 2,456 \\
\hline Direct investment & 465 & 1,190 & 1,411 & 1,046 & 229 & 799 & 1,004 & 1,361 & 1,724 \\
\hline Portfolio investment & -103 & 25 & -493 & 262 & -295 & -295 & -151 & -155 & -162 \\
\hline Financial derivatives & -63 & 46 & 164 & 114 & 114 & 114 & 114 & 114 & 114 \\
\hline Other investment & 1,803 & 3,587 & 4,103 & 458 & $-2,631$ & $-1,318$ & -188 & 501 & 780 \\
\hline Trade credit & -31 & -5 & 70 & -222 & -163 & -39 & -33 & -39 & -22 \\
\hline MLT loans & 1,729 & 2,668 & 3,762 & 1,867 & $-1,196$ & -752 & 96 & 784 & 1,003 \\
\hline o/w net foreign borrowing & & & & 1,807 & $-1,196$ & -752 & 96 & 249 & 1,093 \\
\hline Disbursements & & & & 5,467 & 1,184 & 2,012 & 5,128 & 5,221 & 6,557 \\
\hline Amortization & 2,188 & 2,281 & 2,242 & 3,661 & 2,380 & 2,764 & 5,031 & 4,973 & 5,464 \\
\hline ST liabilities & 146 & 891 & 218 & $-1,312$ & $-1,311$ & -566 & -286 & -327 & -325 \\
\hline $\mathrm{o} / \mathrm{w}$ nonresident deposits & & & & $-1,071$ & $-1,158$ & -508 & -72 & -70 & -34 \\
\hline Other & -41 & 34 & 54 & 35 & 40 & 40 & 35 & 40 & 40 \\
\hline Errors and omissions & -242 & 101 & -146 & -327 & 0 & 0 & 0 & 0 & 0 \\
\hline Overall balance & 421 & 1,569 & 714 & $-1,346$ & $-3,734$ & $-1,246$ & 278 & 1,349 & 2,004 \\
\hline Prospective official financing (net) & $\ldots$ & $\ldots$ & $\ldots$ & 500 & 2,800 & 2,200 & 300 & -912 & $-2,199$ \\
\hline Financing & -421 & $-1,569$ & -714 & 846 & 934 & -954 & -578 & -436 & 195 \\
\hline Change in reserve assets (increase:-) & -421 & $-1,569$ & -714 & 246 & 334 & $-1,354$ & -683 & 1 & 870 \\
\hline IMF (net) & & & & 600 & 600 & 400 & 105 & -438 & -675 \\
\hline Purchases & & & & 600 & 600 & 400 & 105 & 0 & 0 \\
\hline Repurchases & & & & 0 & 0 & 0 & 0 & 438 & 675 \\
\hline
\end{tabular}

Sources: Latvian authorities and IMF staff estimates and projections. 
Table 4. Latvia: Balance of Payments (Baseline), 2005-13, (Concluded)

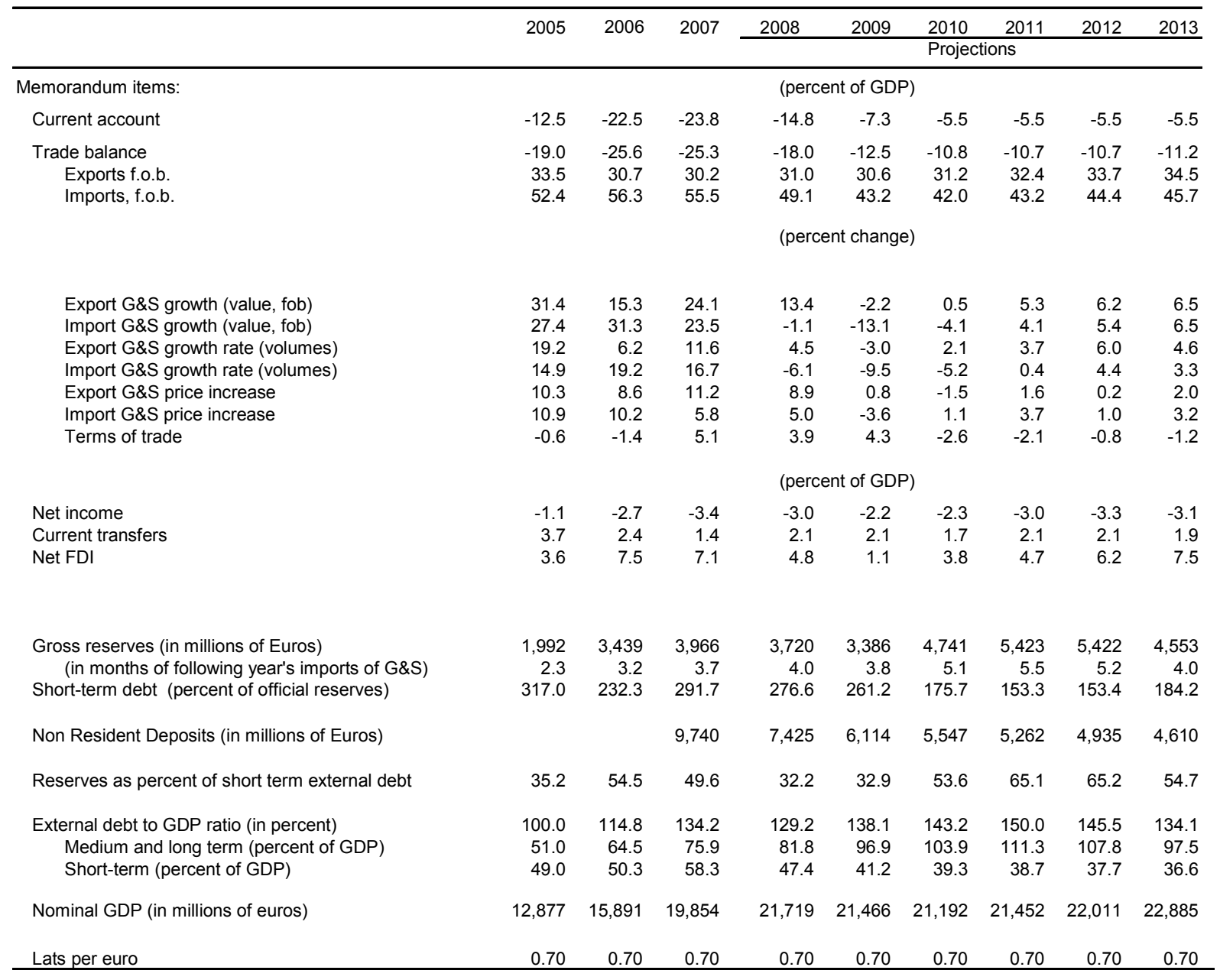

Sources: Latvian authorities and IMF staff estimates and projections. 
Table 5. Latvia: Financial Soundness Indicators, 2002-08

(In percent, unless otherwise indicated)

\begin{tabular}{|c|c|c|c|c|c|c|c|c|c|}
\hline & Dec-02 & Dec-03 & Dec-04 & Dec-05 & Dec-06 & Dec-07 & Jun-08 & Sep-08 & Oct-08 \\
\hline \multicolumn{10}{|l|}{ Commercial banks } \\
\hline \multicolumn{10}{|l|}{ Capital Adequacy } \\
\hline Regulatory capital to risk-weighted assets & 13.1 & 11.7 & 11.7 & 10.1 & 10.2 & 11.1 & 12.2 & 12.3 & $\mathrm{n} / \mathrm{a}$ \\
\hline Regulatory Tier I capital to risk-weighted assets & 12.1 & 10.8 & 10.4 & 8.8 & 8.8 & 9.8 & 11.1 & 11.1 & $\mathrm{n} / \mathrm{a}$ \\
\hline Capital to assets & 8.7 & 8.4 & 8.0 & 7.6 & 7.6 & 7.9 & 8.2 & 8.2 & 8.2 \\
\hline \multicolumn{10}{|l|}{ Asset Quality } \\
\hline Annual growth of bank loans & 30.8 & 41.6 & 46.1 & 59.0 & 56.2 & 37.2 & 21.1 & 17.8 & 16.0 \\
\hline Sectoral distribution of loans (in \% of total loans, stock) & & & 100.0 & 100.0 & 100.0 & 100.0 & 100.0 & 100.0 & 100.0 \\
\hline Agriculture, hunting and related service activities & n.a. & n.a. & 2.6 & 2.2 & 1.8 & 1.6 & 1.6 & 1.7 & $\mathrm{n} / \mathrm{a}$ \\
\hline Construction and real estate activities & n.a. & n.a. & 12.2 & 16.1 & 18.9 & 18.8 & 20.2 & 19.3 & n.a. \\
\hline Industry and trade & n.a. & n.a. & 33.0 & 26.1 & 22.0 & 21.6 & 21.2 & 22.6 & n.a. \\
\hline Financial intermediation & n.a. & n.a. & 9.0 & 10.2 & 8.0 & 6.0 & 6.6 & 6.6 & $\mathrm{n} / \mathrm{a}$ \\
\hline Households & n.a. & n.a. & 29.9 & 34.9 & 39.4 & 40.0 & 39.3 & 38.3 & 38.3 \\
\hline Non-residents & n.a. & n.a. & 13.2 & 10.6 & 9.9 & 12.1 & 11.2 & 11.5 & 11.7 \\
\hline NPLs to gross loans & 2.0 & 1.4 & 1.1 & 0.7 & 0.4 & 0.4 & 0.6 & 0.7 & $\mathrm{n} / \mathrm{a}$ \\
\hline Provisions to NPLs & 78.3 & 89.4 & 99.1 & 98.8 & 116.6 & 129.8 & 122.9 & 118.7 & $\mathrm{n} / \mathrm{a}$ \\
\hline NPLs net of provisions to capital & 2.4 & 0.9 & 0.1 & 0.1 & -0.7 & -1.0 & -0.4 & -0.2 & $\mathrm{n} / \mathrm{a}$ \\
\hline Loans past due over 90 days & $\mathrm{n} / \mathrm{a}$ & $\mathrm{n} / \mathrm{a}$ & $\mathrm{n} / \mathrm{a}$ & $\mathrm{n} / \mathrm{a}$ & 0.5 & 0.8 & 2.1 & 2.5 & $\mathrm{n} / \mathrm{a}$ \\
\hline Share of loans in total assets, banks dealing with residents $1 /$ & 67.5 & 73.1 & 77.6 & 80.8 & 78.5 & 80.4 & 81.2 & 82.9 & 83.5 \\
\hline Share of loans in total assets, banks dealing with non-residents $1 /$ & 28.6 & 30.8 & 32.8 & 38.6 & 48.6 & 48.9 & 52.5 & 54.1 & 55.1 \\
\hline \multicolumn{10}{|l|}{ Earnings and Profitability } \\
\hline ROA (after tax) & 1.5 & 1.4 & 1.7 & 2.1 & 2.1 & 2.0 & 1.5 & 1.2 & 1.1 \\
\hline ROE (after tax) & 16.4 & 16.7 & 21.4 & 27.1 & 25.6 & 24.3 & 17.7 & 14.7 & 13.3 \\
\hline Net interest income to total income & 32.9 & 33.2 & 36.6 & 36.0 & 34.5 & 32.5 & 30.3 & 30.6 & 30.8 \\
\hline Noninterest expenses to total income & 56.2 & 57.2 & 51.8 & 44.6 & 37.5 & 32.3 & 34.6 & 36.5 & 36.9 \\
\hline Trading income to total income & 9.2 & 9.2 & 8.5 & 7.2 & 7.4 & 7.8 & 7.2 & 5.8 & 5.1 \\
\hline Personnel expenses to noninterest expenses & 26.4 & 25.7 & 27.9 & 29.0 & 32.2 & 31.5 & 30.1 & 28.7 & 29.0 \\
\hline \multicolumn{10}{|l|}{ Income from operations with non-residents to total income } \\
\hline Banks dealing with residents $1 /$ & 11.2 & 11.3 & 11.2 & 11.2 & 11.5 & 13.0 & 11.9 & 11.8 & 13.5 \\
\hline Banks dealing with non-residents $1 /$ & 50.1 & 51.5 & 56.3 & 56.2 & 51.8 & 49.2 & 44.8 & 48.4 & 46.5 \\
\hline \multicolumn{10}{|l|}{ Liquidity } \\
\hline Liquid assets to total assets & 38.0 & 33.5 & 33.7 & 26.7 & 23.9 & 25.0 & 21.8 & 19.7 & 19.3 \\
\hline Liquid assets to short term liabilities & 62.1 & 57.9 & 58.1 & 52.3 & 51.1 & 55.7 & 50.7 & 49.1 & 47.6 \\
\hline FX liabilities to total liabilities $2 /$ & 71.8 & 71.0 & 74.6 & 76.3 & 77.1 & 81.7 & 81.0 & 82.2 & 81.5 \\
\hline FX loans to total loans $2 /$ & 66.5 & 67.9 & 71.7 & 73.4 & 74.1 & 81.8 & 82.5 & 83.5 & 83.9 \\
\hline Customers deposits to (non-interbank) loans & 144.5 & 124.3 & 116.3 & 89.1 & 71.3 & 68.2 & 64.7 & 60.7 & 57.5 \\
\hline \multicolumn{10}{|l|}{ Sensitivity to Market Risk } \\
\hline Net open positions in FX to capital $2 /$ & 3.7 & 7.1 & 5.4 & 15.0 & 18.6 & 5.4 & 3.7 & 4.1 & $\mathrm{n} / \mathrm{a}$ \\
\hline Net open positions in EUR to capital & n.a. & 2.5 & 4.0 & 12.2 & 16.4 & 3.2 & 1.8 & 2.3 & $\mathrm{n} / \mathrm{a}$ \\
\hline Net open positions in USD to capital & n.a. & 3.1 & 1.4 & 1.4 & 1.9 & 1.1 & 1.0 & 1.3 & $\mathrm{n} / \mathrm{a}$ \\
\hline Net open positions in equities to capital & n.a. & 1.6 & 2.2 & 3.9 & 1.9 & 1.1 & 0.5 & 0.1 & $\mathrm{n} / \mathrm{a}$ \\
\hline \multicolumn{10}{|l|}{ Nonfinancial Enterprises 31} \\
\hline Total debt to equity & 120.2 & 124.2 & 133.8 & 175.5 & 194.9 & 167.0 & 172.5 & $\mathrm{n} / \mathrm{a}$ & $\mathrm{n} / \mathrm{a}$ \\
\hline Return on equity & 13.6 & 15.9 & 21.6 & 21.3 & 31.3 & 23.0 & 10.1 & $\mathrm{n} / \mathrm{a}$ & $\mathrm{n} / \mathrm{a}$ \\
\hline Earnings to interest expenses & 270.1 & 332.0 & 427.1 & 457.9 & 630.1 & 683.0 & 414.7 & $\mathrm{n} / \mathrm{a}$ & $\mathrm{n} / \mathrm{a}$ \\
\hline \multicolumn{10}{|l|}{ Households } \\
\hline Household debt to GDP & 7.5 & 12.6 & 18.6 & 28.6 & 40.9 & 44.9 & 44.1 & 44.4 & $\mathrm{n} / \mathrm{a}$ \\
\hline Household debt service to GDP 4/ & 0.6 & 0.7 & 0.9 & 1.3 & 1.8 & 2.6 & 2.8 & 2.9 & $\mathrm{n} / \mathrm{a}$ \\
\hline \multicolumn{10}{|l|}{ Real Estate Markets } \\
\hline Real estate prices annual growth rate $5 /$ & n.a. & n.a. & 23.4 & 61.5 & 69.0 & -7.3 & -27.2 & -31.0 & -31.9 \\
\hline Residential real estate loans to total loans $6 /$ & 11.2 & 16.2 & 21.0 & 25.1 & 30.0 & 31.6 & 31.0 & 30.2 & 30.2 \\
\hline Commercial real estate loans to total loans $6 /$ & 7.9 & 9.9 & 10.7 & 15.2 & 18.8 & 17.8 & 19.8 & 19.6 & 19.4 \\
\hline \multicolumn{10}{|l|}{ Memorandum Items } \\
\hline Number of banks dealing with residents $1 /$ & 9 & 9 & 8 & 8 & 9 & 9 & 12 & 13 & 12 \\
\hline Number of banks dealing with non-residents $1 /$ & 14 & 14 & 15 & 15 & 13 & 14 & 13 & 13 & 14 \\
\hline Assets of banks dealing with residents/Total banking system assets $1 /$ & 49.5 & 51.1 & 51.3 & 59.2 & 66.1 & 60.8 & 64.8 & 63.6 & 61.2 \\
\hline Assets of banks dealing with non-residents/Total banking system assets $1 /$ & 50.5 & 48.9 & 48.7 & 40.8 & 33.9 & 39.2 & 35.2 & 36.4 & 38.8 \\
\hline
\end{tabular}

Source: CSB, BoL, FCMC, Latvian Leasing Association, IMF staff calculations.

1/ Banks dealing with residents (non-residents) are defined as banks in which non-resident non-MFI deposits are below (above) 20 percent of their assets. 2/ Including euro-denominated positions.

$3 / 3$ quarters of 2007 and 1st half of 2008; data not comparable to yearly figures due to different sample (not annualized)

$4 /$ Interest payments only.

5/ Prices of typical serial apartments in Riga. Source: Real estate company Latio

$6 /$ Loans to residents only to total loans (including loans to non-residents). 
Table 6. Bank of Latvia Balance Sheet 2004-09

(End-period; in millions of lats unless otherwise stated)

\begin{tabular}{|c|c|c|c|c|c|c|}
\hline & 2004 & 2005 & 2006 & 2007 & \multicolumn{2}{|c|}{ Projections } \\
\hline & \multicolumn{6}{|c|}{ (At current exchange rates) } \\
\hline Net foreign assets (NFA) & 1,039 & 1,387 & 2,414 & 2,769 & 2,000 & 2,187 \\
\hline $\begin{array}{l}\text { Net domestic assets (NDA) } \\
\text { of which: }\end{array}$ & -83 & -36 & -166 & -298 & 497 & -391 \\
\hline Banks (net, excluding bank reserves with the BoL) & 12 & -8 & -44 & 7 & 870 & 50 \\
\hline General government (net) & -14 & 33 & -50 & -171 & -172 & -355 \\
\hline Fixed assets & 36 & 35 & 33 & 33 & 34 & 34 \\
\hline Other domestic assets (net) & -24 & -10 & -1 & -3 & -2 & -8 \\
\hline Capital and reserves & 92 & 87 & 104 & 164 & 233 & 112 \\
\hline Bank reserves with the BoL & 229 & 474 & 1,175 & 1,422 & 1,351 & 664 \\
\hline $\begin{array}{l}\text { Base money } \\
\text { of which, lats in circulation }\end{array}$ & 957 & 1,351 & 2,249 & 2,471 & 2,497 & $\begin{array}{l}1,796 \\
1,132\end{array}$ \\
\hline \multirow{2}{*}{ of which, lats in circulation } & 727 & 786 & 1,074 & 1,049 & 1,145 & 1,132 \\
\hline & \multicolumn{6}{|c|}{ (Year-on-year growth rates, percent) } \\
\hline Net foreign assets & 26.1 & 33.5 & 74.1 & 14.7 & -27.8 & 9.3 \\
\hline Base money & 25.6 & 41.1 & 66.5 & 9.9 & 1.0 & -28.1 \\
\hline \multirow[t]{2}{*}{ Lats in circulation } & 6.6 & 8.1 & 36.6 & -2.3 & 9.1 & -1.2 \\
\hline & \multicolumn{6}{|c|}{ (Contribution to year-on-year growth in base money, percent) } \\
\hline Net foreign assets & 28.2 & 36.3 & 76.1 & 15.8 & -31.1 & 7.5 \\
\hline Net domestic assets & -2.8 & 4.9 & -9.6 & -5.9 & 32.2 & -35.5 \\
\hline \multicolumn{7}{|l|}{ Memorandum items: } \\
\hline $\mathrm{NFA} /$ monetary base & 108.6 & 102.7 & 107.4 & 112.1 & 80.1 & 121.8 \\
\hline Reserve money/GDP & 12.9 & 14.9 & 20.1 & 17.7 & 16.4 & 11.9 \\
\hline GDP (yearly total) & 7,435 & 9,059 & 11,172 & 13,957 & 15,268 & 15,091 \\
\hline
\end{tabular}

Source: Bank of Latvia and IMF staff estimates and projections. 
Table 7. Latvia: Monetary Survey, 2004-09

(End-period; in millions of lats unless otherwise stated)

\begin{tabular}{|c|c|c|c|c|c|c|}
\hline & 2004 & 2005 & 2006 & 2007 & \multicolumn{2}{|c|}{ Projections } \\
\hline & \multicolumn{6}{|c|}{ (At current exchange rates) } \\
\hline Net foreign assets (NFA) & -231 & $-1,327$ & $-2,635$ & $-4,483$ & $-6,840$ & $-5,859$ \\
\hline Bank of Latvia & 1,039 & 1,387 & 2,414 & 2,769 & 2,000 & 2,187 \\
\hline Domestic money banks & $-1,270$ & $-2,714$ & $-5,049$ & $-7,252$ & $-8,840$ & $-8,046$ \\
\hline Net domestic assets (NDA) & 3,099 & 5,311 & 8,115 & 10,654 & 13,059 & 11,894 \\
\hline Domestic credit & 3,948 & 6,441 & 9,877 & 13,018 & 15,011 & 14,593 \\
\hline Credit to private sector & 3,775 & 6,175 & 9,777 & 13,106 & 14,813 & 14,674 \\
\hline Households & 1,331 & 2,452 & 4,303 & 5,989 & 6,512 & 6,496 \\
\hline Enterprises & 2,444 & 3,723 & 5,474 & 7,117 & 8,301 & 8,178 \\
\hline Government, net & 173 & 266 & 101 & -87 & 198 & -81 \\
\hline Other Items, net & -849 & $-1,130$ & $-1,763$ & $-2,364$ & $-1,952$ & $-2,699$ \\
\hline Broad money & 2,868 & 3,985 & 5,480 & 6,171 & 6,219 & 6,035 \\
\hline Domestic money supply (M2) & 2,018 & 2,685 & 3,620 & 3,630 & 3,817 & 3,773 \\
\hline Currency held by public & 645 & 786 & 969 & 900 & 935 & 936 \\
\hline Private deposits in lats & 1,373 & 1,899 & 2,651 & 2,730 & 2,882 & 2,837 \\
\hline Household deposits in lats & 713 & 1,012 & 1,471 & 1,389 & 1,472 & 1,475 \\
\hline Enterprise deposits in lats & 660 & 888 & 1,180 & 1,341 & 1,410 & 1,362 \\
\hline Monetary base & 957 & 1,351 & 2,249 & 2,471 & 2,497 & 1,796 \\
\hline Total domestic deposits & 2,223 & 3,198 & 4,511 & 5,271 & 5,304 & 5,139 \\
\hline of which, residents' foreign currency deposits & 850 & 1,299 & 1,860 & 2,541 & 2,422 & 2,302 \\
\hline Non resident non-bank deposits & 2,749 & 2,925 & 3,017 & 4,513 & 3,700 & 3,071 \\
\hline \multirow[t]{2}{*}{ Total foreign currency deposits } & 3,599 & 4,224 & 4,877 & 7,054 & 6,122 & 5,373 \\
\hline & \multicolumn{6}{|c|}{ (Year-on-year growth rates, percent) } \\
\hline Credit to private sector & 46.8 & 63.6 & 58.3 & 34.0 & 13.0 & -0.9 \\
\hline Households & 74.8 & 84.2 & 75.5 & 39.2 & 8.7 & -0.2 \\
\hline Enterprises & 35.0 & 52.4 & 47.0 & 30.0 & 16.6 & -1.5 \\
\hline Broad money & 27.0 & 38.9 & 37.5 & 12.6 & 0.8 & -3.0 \\
\hline Private deposits in lats & 29.2 & 42.0 & 45.4 & -5.6 & 5.9 & 0.2 \\
\hline Foreign currency deposits & 37.2 & 17.4 & 15.4 & 44.7 & -13.2 & -12.2 \\
\hline \multicolumn{7}{|l|}{ Memorandum items: } \\
\hline Broad money/GDP & 38.6 & 44.0 & 49.1 & 44.2 & 40.7 & 40.0 \\
\hline Residents' foreign currency deposits/total domestic deposits & 38.2 & 40.6 & 41.2 & 48.2 & 45.7 & 44.8 \\
\hline Broad money multiplier (broad money/reserve money) & 3.0 & 3.0 & 2.4 & 2.5 & 2.5 & 3.4 \\
\hline Private credit (percent of GDP) & 50.8 & 68.2 & 87.5 & 93.9 & 97.0 & 97.2 \\
\hline GDP (yearly total) & 7,435 & 9,059 & 11,172 & 13,957 & 15,268 & 15,091 \\
\hline
\end{tabular}

Source: Bank of Latvia and IMF staff estimates and projections. 
Table 8. Latvia. Macroeconomic Framework, 2007-13

(Percentage change, unless otherwise indicated)

\begin{tabular}{|c|c|c|c|c|c|c|c|}
\hline & 2007 & 2008 & 2009 & 2010 & 2011 & 2012 & 2013 \\
\hline & & \multicolumn{6}{|c|}{ Projections } \\
\hline \multicolumn{8}{|l|}{ Output and demand } \\
\hline Real GDP & 10.3 & -2.0 & -5.0 & -3.0 & 1.5 & 2.0 & 2.5 \\
\hline Consumption & 12.3 & -5.1 & -6.7 & -5.5 & -0.4 & 1.6 & 1.8 \\
\hline Private consumption & 13.9 & -6.3 & -7.5 & -6.0 & -0.6 & 1.5 & 1.7 \\
\hline Public consumption & 4.8 & 1.0 & -3.0 & -3.0 & 0.5 & 2.0 & 2.0 \\
\hline Gross fixed capital formation & 8.4 & -10.0 & -12.0 & -8.5 & 1.0 & 1.5 & 2.5 \\
\hline Exports of goods and services & 11.1 & 4.5 & -3.0 & 2.1 & 3.7 & 6.0 & 4.6 \\
\hline Imports of goods and services & 15.0 & -6.1 & -9.5 & -5.2 & 0.4 & 4.4 & 3.3 \\
\hline \multicolumn{8}{|l|}{ Contributions to growth } \\
\hline Domestic demand & 15.2 & -8.0 & -9.6 & -7.1 & 0.0 & 1.7 & 2.1 \\
\hline Net exports & -4.9 & 5.9 & 4.7 & 4.1 & 1.6 & 0.4 & 0.4 \\
\hline & \multicolumn{7}{|c|}{ (In percent of GDP) } \\
\hline \multicolumn{8}{|l|}{ Fiscal sector } \\
\hline General government revenues & 38.4 & 38.0 & 34.8 & 36.6 & 38.6 & 40.8 & 41.7 \\
\hline General government expenditure & 37.7 & 41.1 & 39.8 & 41.4 & 41.4 & 41.3 & 40.6 \\
\hline Basic Balance & 0.7 & -3.0 & -4.9 & -4.9 & -2.9 & -0.5 & 1.1 \\
\hline Balance (including bank restructuring costs) & 0.7 & -5.4 & -17.3 & -6.6 & -2.9 & -0.5 & 1.1 \\
\hline General government gross debt & 8.3 & 14.3 & 33.7 & 46.0 & 50.2 & 46.1 & 33.5 \\
\hline \multicolumn{8}{|l|}{ Savings and investment } \\
\hline Domestic saving & 15.4 & 17.1 & 22.2 & 24.7 & 24.6 & 25.1 & 25.0 \\
\hline Private & 7.2 & 13.6 & 22.4 & 24.8 & 22.7 & 20.9 & 19.2 \\
\hline Public 2/ & 8.3 & 3.5 & -0.2 & -0.1 & 1.9 & 4.2 & 5.8 \\
\hline Foreign saving $3 /$ & -21.8 & -13.3 & -5.4 & -2.6 & -2.3 & -2.1 & -2.0 \\
\hline Investment & 37.2 & 30.5 & 27.5 & 27.3 & 26.9 & 27.2 & 27.0 \\
\hline Private & 31.4 & 25.5 & 22.8 & 22.6 & 22.2 & 22.5 & 22.3 \\
\hline Public & 5.8 & 4.9 & 4.7 & 4.7 & 4.7 & 4.7 & 4.7 \\
\hline \multicolumn{8}{|l|}{ External sector } \\
\hline Current account balance & -23.8 & -14.8 & -7.3 & -5.5 & -5.5 & -5.5 & -5.5 \\
\hline Net foreign liabilities & 78.6 & 77.9 & 79.1 & 82.9 & 84.7 & 84.9 & 83.5 \\
\hline \multicolumn{8}{|l|}{ External debt } \\
\hline Gross & 134.1 & 129.2 & 138.1 & 143.2 & 150.0 & 145.5 & 134.1 \\
\hline Net 4/ & 51.0 & 54.6 & 65.1 & 63.7 & 67.7 & 64.6 & 59.4 \\
\hline \multicolumn{8}{|l|}{ HICP inflation } \\
\hline Period average (in percent) & 10.1 & 15.5 & 5.9 & 2.2 & 1.3 & 1.0 & 1.0 \\
\hline End-period (in percent) & 14.0 & 11.9 & 3.3 & 1.9 & 1.0 & 0.9 & 1.2 \\
\hline \multicolumn{8}{|l|}{ Unemployment } \\
\hline Period average (in percent) & 6.2 & 6.7 & 9.0 & 11.0 & 11.2 & 10.6 & 9.5 \\
\hline \multicolumn{8}{|l|}{ Memorandum items } \\
\hline REER (CPI-based, 2000=100) & 100.1 & 105.3 & 100.0 & 98.8 & 95.5 & 92.7 & 90.8 \\
\hline Gross official reserves (in billions of euros) & 4.0 & 3.7 & 3.4 & 4.7 & 5.4 & 5.4 & 4.6 \\
\hline Nominal GDP (in billions of lats) & 14.0 & 15.3 & 15.1 & 14.9 & 15.1 & 15.5 & 16.1 \\
\hline Nominal GDP (in billions of euro) & 19.9 & 21.7 & 21.5 & 21.2 & 21.5 & 22.0 & 22.9 \\
\hline
\end{tabular}

Sources: Latvian Authorities, Fund Staff Calculations.

$1 /$ Includes 2nd pillar contributions. Accrual basis.

2/ Defined as the sum of the current account deficit and the capital account deficit

$3 /$ Gross external debt liabilities minus gross external debt assets and international reserves. 
Table 9: Latvia: Program Financing, 2008-11 (In millions of euros)

\begin{tabular}{|c|c|c|c|c|c|c|c|c|c|}
\hline & \multirow{3}{*}{$\begin{array}{l}2008 \\
\text { Q4 1/ } \\
\text { Proj. }\end{array}$} & \multicolumn{4}{|c|}{2009} & \multirow{3}{*}{$\begin{array}{l}2009 \\
\text { Proj. }\end{array}$} & \multirow{3}{*}{$\begin{array}{l}2010 \\
\text { Proj. }\end{array}$} & \multirow{3}{*}{$\begin{array}{l}2011 \\
\text { Mar. } \\
\text { Proj. }\end{array}$} & \multirow{3}{*}{$\begin{array}{c}2008-11 \\
\text { Total } \\
\text { Projection }\end{array}$} \\
\hline & & Mar. & Jun. & Sep. & Dec. & & & & \\
\hline & & \multicolumn{4}{|c|}{ Projection } & & & & \\
\hline Total financing requirements & $-2,532$ & $-1,950$ & $-1,924$ & $-1,166$ & $-1,162$ & $-6,201$ & $-5,511$ & $-1,867$ & $-16,111$ \\
\hline Current account deficit & -605 & -481 & -381 & -376 & -329 & $-1,566$ & $-1,161$ & -259 & $-3,591$ \\
\hline $\begin{array}{l}\text { Medium and long term debt amortization 2/ } \\
\text { Public sector } \\
\text { MFls } \\
\text { Corporate sector }\end{array}$ & $\begin{array}{l}-846 \\
-180 \\
-266 \\
-400\end{array}$ & $\begin{array}{r}-544 \\
-5 \\
-382 \\
-156\end{array}$ & $\begin{array}{r}-892 \\
-5 \\
-731 \\
-156\end{array}$ & $\begin{array}{r}-399 \\
-5 \\
-237 \\
-156\end{array}$ & $\begin{array}{r}-544 \\
-5 \\
-383 \\
-156\end{array}$ & $\begin{array}{r}-2,380 \\
-21 \\
-1,734 \\
-625\end{array}$ & $\begin{array}{r}-2,764 \\
-70 \\
-2,059 \\
-635\end{array}$ & $\begin{array}{r}-1,275 \\
-18 \\
-776 \\
-482\end{array}$ & $\begin{array}{r}-7,265 \\
-288 \\
-4,835 \\
-2,142\end{array}$ \\
\hline Portfolio investment and financial derivatives (net) & 56 & -71 & -156 & -9 & 56 & -181 & -181 & -71 & -376 \\
\hline Non-resident deposits (including MFIs) $3 /$ & $-1,077$ & -619 & -312 & -194 & -186 & $-1,311$ & -566 & -86 & $-3,040$ \\
\hline Trade credit (net) $4 /$ & -61 & -84 & -32 & -38 & -9 & -163 & -39 & 25 & -238 \\
\hline Recapitalization by foreign parent banks & 0 & -150 & -150 & -150 & -150 & -600 & -800 & -200 & $-1,600$ \\
\hline Total financing sources & 1,932 & 1,750 & 1,724 & 1,066 & 1,062 & 5,601 & 5,111 & 1,762 & 14,406 \\
\hline $\begin{array}{l}\text { Medium and long term debt } \\
\text { Public sector } \\
\text { MFIs } \\
\text { Corporate sector }\end{array}$ & $\begin{array}{r}671 \\
150 \\
500 \\
21\end{array}$ & $\begin{array}{r}230 \\
2 \\
166 \\
63\end{array}$ & $\begin{array}{r}438 \\
2 \\
373 \\
63\end{array}$ & $\begin{array}{r}218 \\
2 \\
153 \\
63\end{array}$ & $\begin{array}{r}298 \\
2 \\
233 \\
63\end{array}$ & $\begin{array}{r}1,184 \\
8 \\
926 \\
250\end{array}$ & $\begin{array}{r}2,012 \\
49 \\
1,582 \\
381\end{array}$ & $\begin{array}{r}1,258 \\
0 \\
776 \\
482\end{array}$ & $\begin{array}{r}5,125 \\
207 \\
3,783 \\
1,134\end{array}$ \\
\hline Direct investment, net & 134 & 18 & -18 & 47 & 181 & 229 & 799 & 103 & 1,265 \\
\hline Capital account inflows (EU/EIB) & 50 & 75 & 100 & 120 & 120 & 415 & 615 & 170 & 1,250 \\
\hline Other & 10 & 10 & 10 & 10 & 10 & 40 & 40 & 5 & 94 \\
\hline Recapitalization by foreign parent banks 5 / & 0 & 150 & 150 & 150 & 150 & 600 & 800 & 200 & 1,600 \\
\hline $\begin{array}{l}\text { Prospective official financing (exc. IMF) } \\
\text { European Union }\end{array}$ & $\begin{array}{r}500 \\
0\end{array}$ & $\begin{array}{r}600 \\
1,000\end{array}$ & $\begin{array}{l}1,500 \\
1,200\end{array}$ & $\begin{array}{l}500 \\
500\end{array}$ & $\begin{array}{l}200 \\
200\end{array}$ & $\begin{array}{l}2,800 \\
2,900\end{array}$ & $\begin{array}{r}\mathbf{2 , 2 0 0} \\
100\end{array}$ & $\begin{array}{l}300 \\
100\end{array}$ & $\begin{array}{l}5,800 \\
3,100\end{array}$ \\
\hline Nordic Countries & 0 & 0 & 0 & 0 & 0 & 0 & 1,800 & 0 & 1,800 \\
\hline World Bank & 0 & 0 & 200 & 0 & 0 & 200 & 0 & 200 & 400 \\
\hline Other (Estonia, Czech Republic, Poland, EBRD) & 0 & 100 & 100 & 0 & 0 & 200 & 300 & 0 & 500 \\
\hline Central bank bridge & 500 & -500 & 0 & 0 & 0 & -500 & 0 & 0 & 0 \\
\hline Change in gross reserves (increase -) & 567 & 666 & -456 & 21 & 103 & 334 & $-1,354$ & -274 & -728 \\
\hline Financing gap & 600 & 200 & 200 & 100 & 100 & 600 & 400 & 105 & 1,705 \\
\hline Prospective Fund credit & 600 & 200 & 200 & 100 & 100 & 600 & 400 & 105 & 1,705 \\
\hline
\end{tabular}

Sources: IMF staff estimates and projections.

1/ Rollover assumptions based on actual refinancing until end-November and projected disbursements in December.

2/ Financing difficulties expected in both 2009 and 2010. Rollover rates: 2009: foreign-affiliated banks, 80 percent; domestic and other banks, 40 percent; public sector, 40 percent; corporate sector 40 percent. 2010: foreign-affiliated banks, 80 percent;

3/ Non-resident deposit and other liquid liabilities outflows expected to continue in 2009 and 2010. Ouflows: 16.9 percent in 2009; 9.2 percent in 2010.

4/ Net trade credit expected to contract in line with export and import volumes in 2009, and expand with trade in 2010-11.

5/ Presents an upper bound on recapitalization requirements based on stress tests, subject to usual caveats. 
Table 10. Latvia: Schedule of Reviews and Purchases

\begin{tabular}{|c|c|c|c|}
\hline \multirow[b]{2}{*}{ Date } & \multicolumn{2}{|c|}{ Amount of purchase } & \multirow[b]{2}{*}{ Conditions } \\
\hline & Millions of SDRs & Percent of quota & \\
\hline December 23, 2008 & 535.344 & 422.2 & Approval of arrangement \\
\hline February 15, 2009 & 178.448 & 140.7 & First review and end-December 2008 performance criteria \\
\hline May 15, 2009 & 178.448 & 140.7 & Second review and end-March 2009 performance criteria \\
\hline August 15, 2009 & 89.224 & 70.4 & Third review and end-June 2009 performance criteria \\
\hline November 15, 2009 & 89.224 & 70.4 & Fourth review and end-September 2009 performance criteria \\
\hline February 15, 2010 & 89.224 & 70.4 & Fifth review and end-December 2009 performance criteria \\
\hline May 15, 2010 & 89.224 & 70.4 & Sixth review and end-March 2010 performance criteria \\
\hline August 15, 2010 & 89.224 & 70.4 & Seventh review and end-June 2010 performance criteria \\
\hline November 15, 2010 & 89.224 & 70.4 & Eighth review and end-September 2010 performance criteria \\
\hline February 15, 2011 & 94.042 & 74.2 & Ninth review and end-December 2010 performance criteria \\
\hline Total & 1521.626 & 1200.0 & \\
\hline
\end{tabular}

Source: IMF staff estimates. 
Table 11. Latvia: Indicators of Fund Credit, 2008-16 (in millions SDR)

\begin{tabular}{|c|c|c|c|c|c|c|c|c|c|}
\hline & 2008 & 2009 & 2010 & 2011 & 2012 & 2013 & 2014 & 2015 & 2016 \\
\hline \multicolumn{10}{|l|}{ Existing Fund credit } \\
\hline Stock 1/ & $\ldots$ & $\ldots$ & $\ldots$ & $\ldots$ & $\ldots$ & $\ldots$ & $\ldots$ & $\ldots$ & $\ldots$ \\
\hline Obligations & $\ldots$ & $\cdots$ & $\ldots$ & $\ldots$ & $\ldots$ & $\ldots$ & $\ldots$ & $\ldots$ & $\ldots$ \\
\hline \multicolumn{10}{|l|}{ Proposed Stand-By Arrangement } \\
\hline \multicolumn{10}{|l|}{ Purchases } \\
\hline Stock 1/ & 535.3 & 1070.7 & 1427.6 & 1521.6 & 1131.3 & 529.0 & 170.3 & 11.8 & 0.0 \\
\hline Obligations & 2.7 & 24.8 & 43.2 & 53.9 & 441.4 & 634.7 & 368.9 & 160.7 & 11.9 \\
\hline Repurchase 2/ & 0.0 & 0.0 & 0.0 & 0.0 & 390.4 & 602.3 & 358.7 & 158.6 & 11.8 \\
\hline Charges & 2.7 & 24.8 & 43.2 & 53.9 & 51.0 & 32.5 & 10.2 & 2.1 & 0.1 \\
\hline \multicolumn{10}{|l|}{ Stock of existing and prospective Fund credit } \\
\hline In percent of quota & 422.2 & 844.4 & 1125.9 & 1200.0 & 892.2 & 417.2 & 134.3 & 9.3 & 0.0 \\
\hline In percent of GDP & 2.8 & 5.6 & 7.5 & 7.9 & 5.8 & 2.6 & 0.8 & 0.1 & $\ldots$ \\
\hline In percent of exports of goods and services & 6.1 & 12.5 & 16.6 & 16.8 & 11.7 & 5.1 & 1.5 & 0.1 & $\ldots$ \\
\hline In percent of gross reserves & 16.1 & 35.4 & 33.8 & 31.4 & 23.4 & 13.0 & 3.6 & 0.2 & $\ldots$ \\
\hline \multicolumn{10}{|c|}{ Obligations to the Fund from existing and prospective Fund arrangements } \\
\hline In percent of quota & 2.1 & 19.6 & 34.1 & 42.5 & 348.1 & 500.6 & 290.9 & 126.7 & 9.3 \\
\hline In percent of GDP & 0.0 & 0.1 & 0.2 & 0.3 & 2.2 & 3.1 & 1.7 & 0.7 & $\ldots$ \\
\hline In percent of exports of goods and services & 0.0 & 0.3 & 0.5 & 0.6 & 4.6 & 6.2 & 3.3 & 1.4 & $\ldots$ \\
\hline In percent of gross reserves & 0.1 & 0.8 & 1.0 & 1.1 & 9.1 & 15.6 & 7.8 & 2.6 & $\ldots$ \\
\hline
\end{tabular}

Source: IMF staff estimates.

1/ End-period.

2/ Repayment schedule based on repurchase obligations 


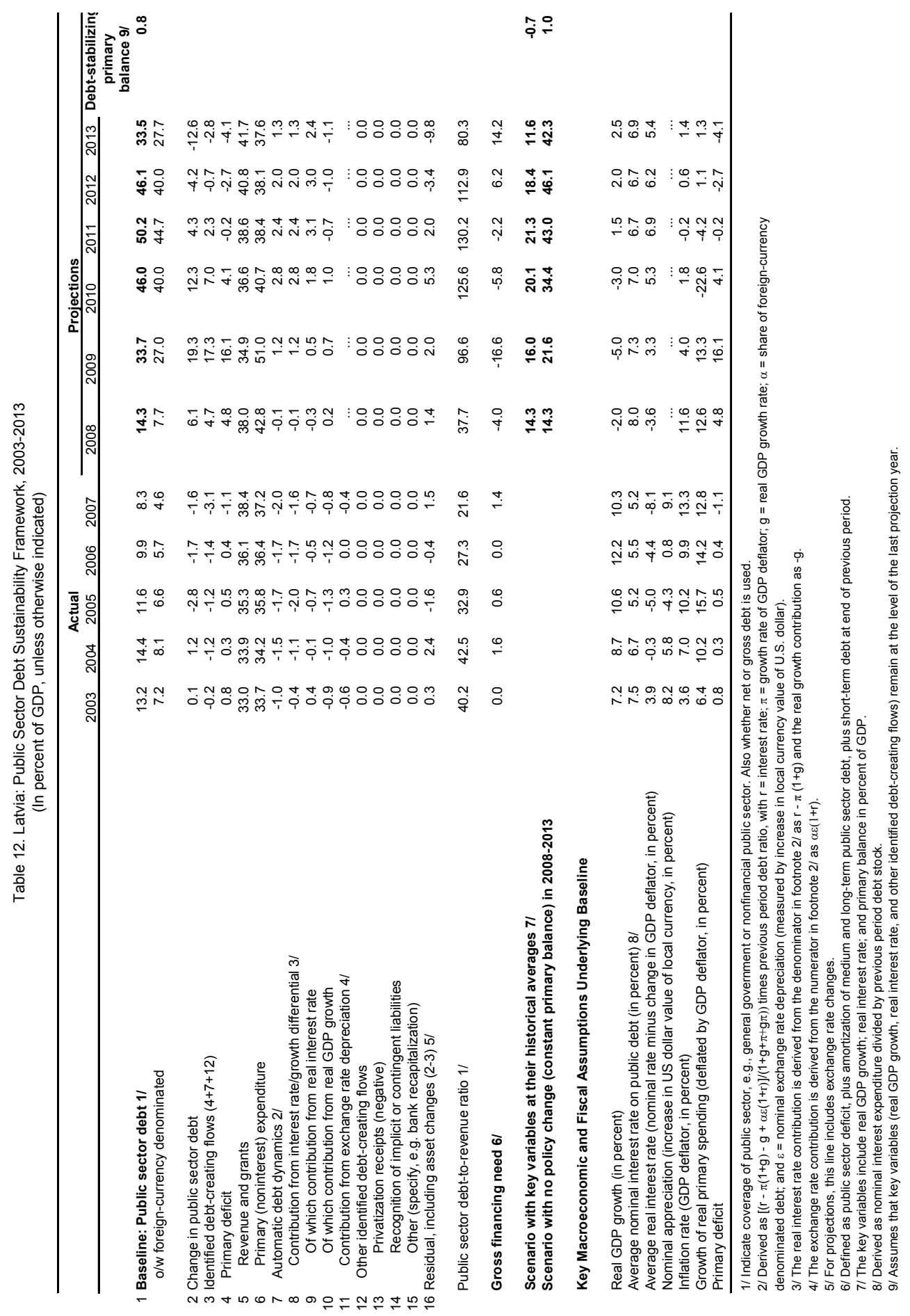




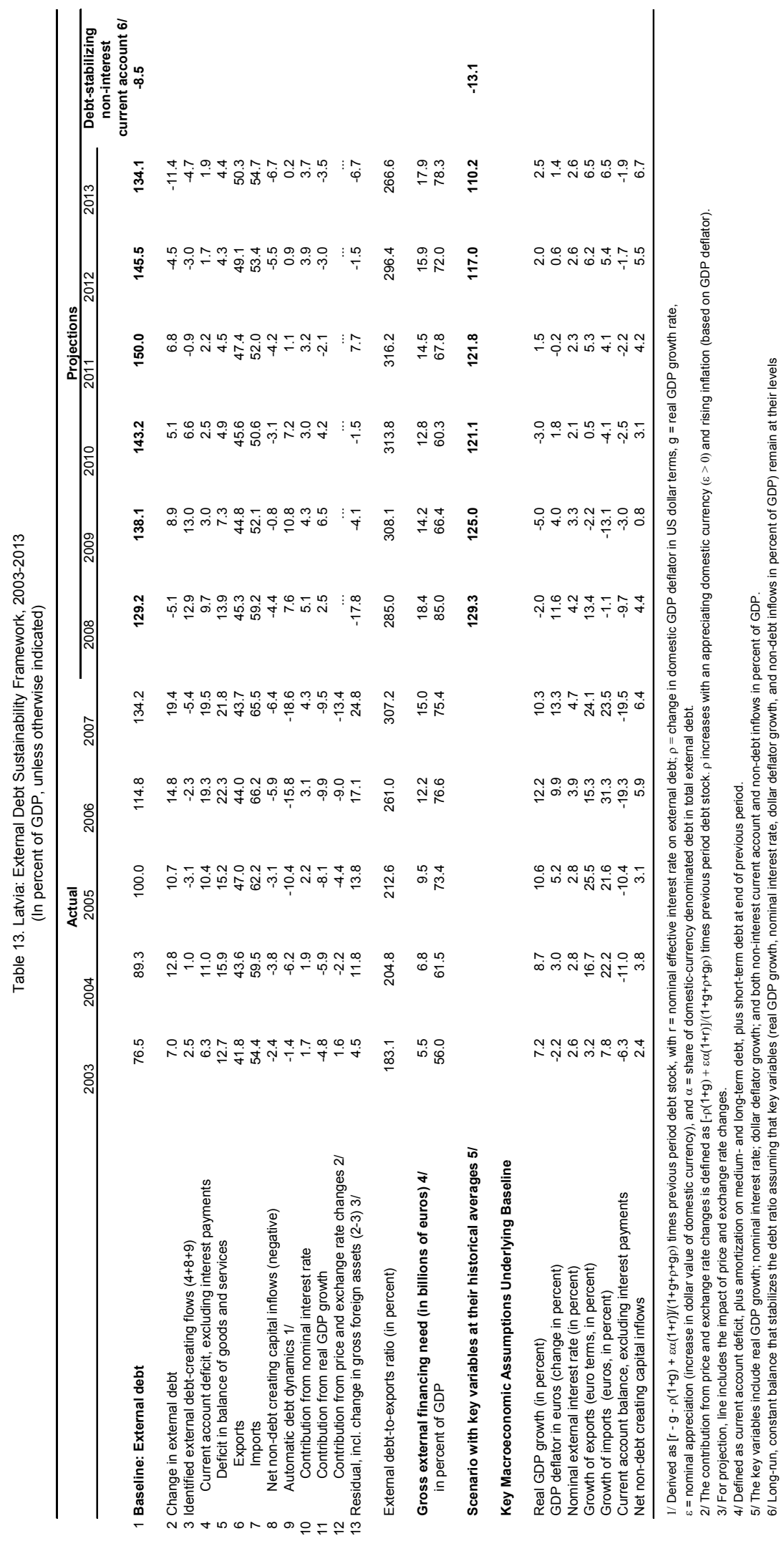


ATTACHMENT I. LATVIA: LETTER OF INTENT

Riga, December 18, 2008

Mr. Dominique Strauss-Kahn

Managing Director

International Monetary Fund

Washington, DC 20431

Dear Mr. Strauss-Kahn:

1. Financial market strains in Latvia have intensified in past weeks as events in global markets have accentuated the existing challenges facing our economy. In response, the Government and the Bank of Latvia (BoL) have developed a comprehensive strategy to counter financing pressures in the near term, and put the economy on a sustainable footing in the long term. The support of the EU, under the balance of payment financing facility, together with bilateral and multilateral commitments demonstrates the international community's backing for our reform strategy. In this context, we request that the IMF support our program through a 27-month Stand-By Arrangement (SBA) in the amount equivalent to SDR1.521626 billion (1,200.02 percent of quota or $€ 1.7$ billion) covering the period December 2008 to March 2011.

\section{We have discussed with IMF Staff our economic program, which is outlined} below. Our main objectives are to (i) stem immediate liquidity pressures, (ii) restore longterm stability by strengthening the banking sector, correcting fiscal imbalances and adopting domestic policies that will improve competitiveness while maintaining our fixed (narrowband) exchange rate, and (iii) strengthen the long-term structural performance of our economy. If successful, these measures would lay the groundwork for our ultimate economic policy goal of entry to the euro-area as soon as possible. We strongly believe that these goals can best be achieved by maintaining the current exchange rate peg and recognize that this calls for extraordinarily strong domestic policies supported by broad political and social consensus.

3. We have already taken a number of measures that demonstrate our commitment to this program. We have taken control of the second largest bank, Parex, and replaced its management. On December 11, the Saeima (parliament) approved a supplementary budget for 2009, which will cap the underlying general government fiscal deficit (excluding possible financial system support measures) at below 5 percent of GDP.

4. The program will be monitored through quantitative performance criteria and indicative targets, structural performance criteria and structural benchmarks, and 
quarterly reviews (Table 1). The attached Technical Memorandum of Understanding sets out specific quarterly targets that are to be observed under the SBA for net international reserves of the Bank of Latvia, net domestic assets of the Bank of Latvia, the cash fiscal balance of the general government, and also the general government wage bill, as well as a requirement of non-accumulation of domestic and external debt arrears of general government (continuous performance criteria). The first review will take place on or after February 15, 2009, and the second review on or after May 15, 2009.

\section{RECENT ECONOMIC PERFORMANCE AND MACROECONOMIC FRAMEWORK FOR 2008-09}

5. Years of strong growth led to a sharp improvement in living standards, but have been accompanied by rising vulnerabilities. Growth, which averaged 9 percent between 2000-07, the fastest in the EU, was driven by private consumption and investment in real estate and other non-tradable sectors. Rapid public expenditure growth added to demand and overheating during this period, while wage growth above productivity improvements exerted upward pressure on consumer price inflation and eroded competitiveness. The strength of import demand also led to current account deficits in excess of 20 percent of GDP in both 2006 and 2007, driving the gross external debt ratio to 135 percent of GDP. Meanwhile, the high level of short-term external debt has exposed Latvia to the risk of a sudden capital stop, and the indebtedness of the private sector (both domestic and external) is approaching levels that could be detrimental to long-term growth.

6. The anti-inflation plan that we introduced in early 2007 represented a first step towards addressing the risks facing our country. The taxation of real estate activity was broadened and new regulations compelled banks to be more circumspect in lending decisions. In 2007, for the first time in recent years, the budget recorded a surplus. Despite a welcome narrowing of the current account since then, competitiveness has deteriorated further and the stock of external liabilities has grown.

\section{Recent international financial market turmoil has magnified these risks,} prompting the need for a further significant strengthening in policies. The availability of external finance has fallen very sharply, due to global developments and downgrades to Latvia's sovereign credit rating. Parex Bank has suffered a significant outflow of deposits since September, compelling us to partially nationalize the institution last month and provide liquidity support. Other domestic banks and companies have found it difficult to rollover their international liabilities. While reductions in reserve requirements and associated intervention by the BoL have helped satisfy demand for foreign exchange, we still see a significant financing requirement emerging in the short term.

8. In view of these uncertainties, our macroeconomic framework for 2009-2011 has been anchored on cautious assumptions. A severe slowdown in output is already 
underway, and we expect weakness in the global economy, financial market deleveraging, and liquidity strains in neighboring countries to lead to a 5 percent contraction in output in 2009. Consumer spending is likely to fall sharply in response to decelerating real wages, tighter credit conditions and rising unemployment, while investment activity is expected to contract. In 2010, we expect a further, more moderate decline in output. As demand slackens, there will be a very sharp fall in core inflation. Notwithstanding the rises in VAT rates discussed below, we expect headline inflation to fall to 2 percent by end-2010, which will help improve competitiveness.

\section{Gross external financing needs, which will be substantial in the coming two} years, will be partially met by external assistance from multilateral and bilateral creditors. Although the current account deficit will narrow to 5 percent by 2010 as imports subside, there will also be a sharp reduction in available capital inflows. Latvian banks and corporates are likely to have difficulties rolling over their borrowings. Relatively higher rollover rates on loans from foreign banks to their local subsidiaries, as well as substantial continued inflows of EU structural and cohesion funds should partially offset this. Nevertheless, we expect an external financing gap of $€ 7.5$ billion through 2011, which will be filled by the IMF, EU, World Bank and bilateral contributions.

10. A gradual economic recovery will emerge over the medium term. Once global deleveraging pressures have eased and Latvian banks have recapitalized, private external financing and domestic lending will resume. Rising inflows of EU grants will increase investment. The sharp slowdown in wage and price inflation will deliver a gradual improvement in competitiveness and eventually, taken together with global economic recovery, raise net exports. Weakness in disposable incomes and continued fiscal restraint will depress consumption, but moderate positive output growth should nonetheless resume from 2011.

\section{POLICIES FOR 2009-2011}

11. Our goals are ambitious, and we recognize that a very strong policy package will be required to deliver them. As the objective of monetary policy must be to support the exchange rate, the burden of adjustment will fall primarily on fiscal and incomes policies. We are convinced that the medium-term fiscal consolidation outlined below will improve competitiveness and restore stability. It will be backed by complementary strategies in areas such as structural reform and debt restructuring. In the near term, however, there will be a significant focus on measures to restore confidence to the banking sector, including the stabilization of Parex. 


\section{A. Financial Sector Policies}

\section{Partially nationalizing and taking control of Parex represent the first steps}

towards effectively resolving the bank. We have already installed a credible and competent new management, and suspended the previous owners from any executive role, and will ensure that the remaining minority shareholders do not benefit from the resolution of the bank. We also will introduce new legislation with a view to providing the legal means of ensuring full government control of the bank to enhance financial stability. The situation warrants close supervision. The new management will promptly develop a resolution plan, consistent with minimizing losses to the state and depositors, considering all options and submit it to the FCMC (prior action). This is necessary to minimize contagion, disruption to the payment system, and to prevent further losses in deposits and international reserves. An international auditing firm will be hired to undertake a comprehensive audit (including an appraisal of past liquidity support) and due diligence assessment, paving the way to recapitalizing the bank to a level that would be sufficient to restore confidence. The rehabilitation process will include a clear exit strategy so that as large a share as possible of the bank's activities are returned swiftly to the private sector. The new management will seek firm commitments from external parties to renew Parex's syndicated funding in the near future.

\section{To restore confidence to the remainder of the banking system, we will develop a comprehensive bank resolution strategy, comprising the following elements:}

- To avert a recurrence of the unexpected recent developments in Parex, we will complete a focused examination of the banking system (structural benchmark for endMarch 2009), to assess whether all banks are solvent and have sufficient liquidity. The work will be conducted by international audit firms (but paid for by the bank undergoing the assessment) and submitted to the FCMC.

- $\quad$ On the basis of this analysis, we will require viable banks that need capital increases to seek private restructuring via outside investors or mergers, or capital support from parent banks. We will also take any necessary measures to provide conditional financial support to these viable banks, in accordance with EU state aid rules. Public support terms and eligibility criteria should be set out in legislation and based on international best practice. We will also take all necessary measures to stabilize deposits in the banking system. We will publish details of this program, and put the recapitalization plan into effect by end-April 2009. We will consult with IMF Staff prior to equity injections.

- Foreign parent banks have recently pledged to maintain credit lines to their Latvian subsidiaries. The FCMC will enhance its existing daily liquidity monitoring by closely tracking foreign banks' exposure in Latvia. In this context, we will strengthen 
our existing contacts with home supervisors of foreign banks, and share information regarding foreign banks under their supervision.

- We stand ready to take full advantage of our existing supervisory powers under Pillar II of Basel II to require additional capital and enhanced liquidity positions where warranted by banks' risk profile.

- We are committed to a fair and equitable treatment of depositors and creditors in the Latvian banking system. Under our deposit insurance system, we are committed to respect the rights of all depositors - both resident and non-resident. In particular, we will remove the partial freeze limiting withdrawal amounts from large noncommercial private deposits in Parex as conditions stabilize. The new management we have installed in Parex is actively engaging the affected depositors to settle their limited arrears arising from this measure and we will maintain good faith efforts to facilitate the settlement of such depositors claims. In the meanwhile, we request temporary Fund approval of the exchange restriction in line with Fund policy, on the basis that it has been imposed for balance of payments reasons, it is temporary and is non-discriminatory.

\section{We will also strengthen our crisis management capacity.}

- $\quad$ The FCMC will enhance its capacity to monitor the financial system by monitoring (bank by bank) assets and liability maturity profiles, including the level of deposits, liquid assets, group exposures, interbank transactions, foreign credit lines, debt rollovers, asset quality and bank capital. The BoL will share information on liquidity support to banks with the FCMC. If financial conditions in any bank appear to deteriorate, the FCMC will stand ready to initiate on-site inspections. The BoL and FCMC will cooperate closely in a situation of financial stress and share all necessary information including the items mentioned above.

- $\quad$ Support from the international community will enable us to provide emergency liquidity assistance (ELA) to solvent banks. This will be facilitated by adopting operational guidelines to clarify procedures for inter-agency coordination, crossborder arrangements and the treatment of collateral by end-December 2008 (structural benchmark). We will consult with IMF Staff prior to further provisions of ELA.

- $\quad$ By the time of the first review, we will review the regulations on emergency liquidity support, and if necessary adopt revised regulations, with the aim of ensuring they are (i) consistent with international practice and (ii) provide for adequate safeguards including, for example, appropriate triggers for supervisory intervention and internal control procedures (structural benchmark for end-January 2009). Fund staff will 
support the authorities in completing this task and in reviewing the early experience of liquidity support provision.

- To promote inter-agency communication, the Domestic Standing group will meet regularly to establish and maintain a common understanding of financial stability responsibilities among the government, BoL and the FCMC. We commit to a regular exchange of information and discussion of financial stability issues.

- $\quad$ The FCMC will be given adequate additional resources to effectively carry out its tasks.

15. The banking laws will be amended to allow the FCMC, BoL and the Ministry of Finance to take timely and effective actions to restore financial stability in systemic crises and to enhance the special bank insolvency regime by end-June 2009 (structural benchmark).

- The amended law will include an authority to empower emergency liquidity assistance against a wide range of appropriate collateral, implement full takeovers of insolvent banks (preferably through bridge banks), and guarantee interbank liabilities.

- The special bank insolvency regime will be enhanced to allow timely bank intervention (before capital falls below the regulatory minimum). The law will authorize the FCMC to appoint a temporary administrator replacing the bank's management board without court approval, and at an earlier stage of a bank's decline. The law will authorize tools to make troubled bank resolution more effective such as: purchase and assumption transactions, sale of part or the whole bank, bridge banks, and reduction in the value of existing shareholders' equity to absorb losses incurred in the resolution process.

- We will put in place mechanisms to ensure that reimbursements under the deposit guarantee fund (DGF) are fast and automatic (through an agent bank). We will also give the DGF temporary powers to increase insurance premia after a payout.

\section{B. Private Debt Restructuring}

16. We recognize the need for a comprehensive strategy to help ensure sustainability of the private-sector's domestic and external debt burden. A large share of the external debt has been contracted by banks which have lent to local corporates and households, whose debt service capacity is likely to suffer in the coming slowdown. While voluntary restructurings will be facilitated to the extent possible, insolvency law tools could also play a role in ensuring effective burden-sharing between the banks and private-sector debtors. With technical assistance from the IMF, we will develop a comprehensive private debt restructuring strategy by end-April 2009 (structural benchmark). 
17. The banking sector will play a central role in our strategy. Capital injections, including from foreign parent banks, will be a primary measure to maintain the solvency of the Latvia banking system. We will align tax treatment to facilitate bank creditors maintaining longer-term support of viable banks, for instance through debt-for-equity swaps. We will seek international assistance to assess by end-March 2009 the merits of establishing an independent asset management entity to take over bad assets from banks and restructure nonperforming loans to maximize recovery over time in a manner that provides initial relief to corporate and household debtors (recognizing the complexities of funding, selection and pricing of assets).

\section{We will amend the Insolvency Law in order to facilitate orderly and efficient} debt restructurings by end-June 2009 (structural benchmark). The corporate insolvency regime will be refined to facilitate workouts between viable enterprises and their creditors. This will include according priority status to new financing by creditors, clarifying class voting by creditors and expedited court approval of rehabilitation plans. We will also assess the effectiveness of the personal bankruptcy framework with a view to rehabilitating household debtors, including by lowering administrative costs and involving participation of creditors in the proceedings. Furthermore, we will continue to encourage loan modifications to avoid unwarranted foreclosures, while addressing inefficiencies in foreclosure procedures that hinder debt resolution.

\section{Monetary and Exchange Rate Policy}

\section{The fixed (narrow band) exchange rate of the lats will remain the anchor for} monetary policy until we adopt the euro. We believe that a pegged exchange rate has served us well over the past 15 years, and that it continues to underpin stability in our increasingly open and euroized economy. It also provides a bridge towards membership of the Eurozone, which will lower risks for banks and the private-sector, as well as promoting long-term growth. Latvia already meets some of the Maastricht criteria. However, determined efforts and a clear strategy will be required to achieve our ambitious goal of meeting the Maastricht criteria as soon as possible, if feasible by 2012.

\section{Maintaining the credibility of the peg necessitates a conservative approach to}

monetary policy. We will maintain existing quantitative limits on foreign currency swaps and main refinancing operations, and ensure that base money remains adequately backed by the Bank of Latvia's net international reserves. Further changes in minimum reserve requirements will be undertaken only after consultation with IMF Staff. 


\section{Fiscal Policy}

21. An immediate and sustained fiscal consolidation will send a strong signal of our commitment to restore stability and prepare for euro adoption. Our strategy is anchored in a medium-term fiscal framework that will lower the deficit to the Maastricht level of 3 percent of GDP by 2011. This will require a structural adjustment of 6 percentage points GDP from 2008 to 2011, to be achieved through comprehensive structural reforms implemented simultaneously at all levels of government. However, social safety nets will be preserved to protect the poor from adverse economic conditions, while investment spending will be maintained at high levels so as not impair long-term growth prospects; EU-financed projects will be ringfenced. Our new approach thus represents a sustainable fiscal consolidation with clearly articulated long-term objectives, which should ensure strong public support, enhance confidence at home and abroad, and spur private-sector growth.

\section{We have already taken a number of measures in support of these goals:}

- In recent months we have controlled budget execution without creating arrears, prioritized essential expenditures, secured tax collection, and pooled available cash. This will allow us to cap the general government deficit (excluding bank restructuring costs) at around 3 percent of GDP in 2008

- We are also acting to prevent budget imbalances from emerging. On December 11 Parliament adopted a supplementary budget for 2009 that takes into account the recent deterioration in the economic outlook and will cap next year's general government fiscal deficit at below 5 percent of GDP (Prior action), implying an adjustment of around 7 percentage points of GDP compared with the budget passed in November.

23. The projected decline in government revenue as a share of GDP will be partially offset by tax increases. The main measures, which were included in the supplementary budget law and should raise approximately $2^{1 / 2} 2$ percent of GDP, are as follows:

- $\quad$ From 2009, increase the standard VAT rate by 3 percentage points, to 21 percent, and the reduced rate from 5 percent to 10 percent. The list of items eligible for the reduced rate will be significantly reduced;

- $\quad$ From 2009, increase excise on fuel, alcohol, non-alcoholic beverages, and coffee;

- $\quad$ Also from 2009, partially reverse the recently adopted increases in non-taxable allowances under the personal income tax (PIT) law, but reduce the PIT rate by 2 percentage points to 23 percent; 
- From 2010, introduce a 10 percent tax rate on all capital income (interest, dividends, royalties, rental income, realized nominal capital gains on shares, realized nominal capital gains on immovable property). This will be applicable to all capital gains on real estate transactions unless minimum times of continuous ownership (five years) and residence (one year) are fulfilled; and

- $\quad$ From 2010, increase real estate and property taxes, which are currently significantly below the OECD average; this will be achieved by removing exemptions in order to broaden the tax base;

- Increase non-tax revenues. User fees will be increased. Dividend pay-out rates by state owned companies will rise from 27-35 percent at present to 50 percent;

- We will seek to improve tax administration with international assistance, although we have not factored significant improvements in collection rates into our projections before 2010 .

24. In 2009 we will cap expenditures at just below 40 percent of GDP. We estimate that this will necessitate cuts of $4 \frac{1}{2}$ percent of GDP over and above what was already factored into the originally adopted central government budget as well as envisaged local government budgets. This will be achieved by (i) approximately 15 percent cuts in compensation of all public sector employees with effect from January 1, 2009; (ii) a pension freeze, (iii) rationalizing subsidies (excluding social support), and outlays on goods and services. There will be no reductions in social support beyond the impact of the wage reduction (which will lower indexed benefits). Moreover, we will seek to improve the targeting of all social safety nets within a social spending budget that increases by 1 percentage point of GDP relative to 2008. However, measures to restructure the banking sector including recapitalizing banks, covering the liabilities of the deposit guarantee fund and providing various liquidity instruments, may entail significant additional fiscal costs.

\section{The 2009 budget has been revised to reflect this lower level of spending. The} supplementary budget determines total spending appropriations for the consolidated central government that are consistent with the targeted fiscal deficit of 4.9 percent of GDP, and sets aside 10 percent of state basic budget appropriations (excluding those relating to EU-financed projects, debt service and payments to the EU budget) in a contingency reserve held by central government. We will submit to Parliament a second supplementary budget law for 2009 to define further the allocation of spending appropriations among spending agencies and ministries and identify clearly programs that should be rationalized by March 31, 2009 (structural performance criterion). The contingency reserve will be reduced to 5 percent of appropriations once the second supplementary budget has been passed. 


\section{Equivalent measures will be taken to ensure that local governments match the} central government's belt-tightening measures. We will sign a protocol (prior action) that stipulates a 15 percent reduction in local government employees' compensation. Local governments will be barred from borrowing except for EU-financed projects and intra-year liquidity needs, and will not receive any central government guarantees for the duration of the program. We will implement fully and without delay the State Audit Office recommendations of September 2008 regarding the assessment of implementation of the 2007 budget and budgets of local governments.

\section{To ensure that fiscal targets are met, we will adopt a decision of the cabinet of} ministers to reform controls on budget execution by end-December 2008 (structural benchmark). The decision will stipulate that appropriations from the central basic budget contingency reserve will be released progressively over the year subject to the objective of meeting the performance criteria and benchmarks set out in the Technical Memorandum of Understanding. The cabinet decision will require all spending ministries and institutions to submit weekly cash-flow projections and proposals for new commitments. Local governments will be required to submit similar reports every fortnight. A committee of finance ministry and Treasury officials will meet weekly to review a consolidated report and propose recommendations to the Prime Minister, who will decide on the level of new commitments to be authorized in the following week. If there are revenue shortfalls, commitments will be immediately reduced to cover only obligatory expenditures. To ensure that expenditure appropriations represent hard ceilings, privatization receipts and other revenues from asset disposals will be treated as financing items.

\section{We are planning further comprehensive structural reforms to achieve a sustainable fiscal position:}

- We will seek assistance from the IMF, EU and bilateral donors to strengthen public financial management in the first quarter of 2009. The goals will be (i) to strengthen the budget formulation process, (ii) improve the Ministry of Finance's spending controls (especially over the wage bill at the general government level), (iii) make the medium-term budget framework operational, (iv) to increase transparency and external oversight in the budget, improve fiscal decentralization, and (v) to adopt a PPP law in accordance with international standards.

- We will put fiscal discipline on a permanent sustainable path, with assistance from IMF and EU staff, by amending the current Budget and Financial Management law to strengthen provisions on financial responsibility, transparency and accountability. These amendments will aim to keep public debt at an appropriate level, set expenditure ceilings, avoid procyclicality in fiscal policy and ultimately allow automatic stabilizers to operate fully by end-June 2009 (Structural benchmark). 
- We have approached the World Bank to seek technical assistance on the comprehensive reforms of the education, civil service, state administration and the healthcare systems that we will launch in 2009. Once completed, these could eventually deliver annual savings of about 2 percent of GDP, including due to staff savings that will commence in 2010.

29. Additional consolidation measures will be needed to attain the deficit target of 3 percent of GDP by 2011. This will include further increasing the VAT rate, additional reductions in public employment and wages, and (from 2010) indexing pensions only to inflation. Attaining the deficit target could be challenging given the considerable uncertainties about the medium-term outlook, and therefore all policy options will be kept under review.

\section{E. Income Policies and Structural Reform}

30. We are strongly committed to wage restraint, which we see as the most effective instrument for restoring competitiveness and correcting external vulnerabilities. We recognize that wages grew too rapidly during the past boom, and as noted above, intend to cut average compensation (wages and bonuses) in the entire public sector by an additional 15 percent in 2009 (relative to the originally adopted budget), with further reductions in 2010-2011. We will also secure commitments from the boards of all publicly owned enterprises to deliver the same levels of reduction in compensation. Working with our partners in the National Tripartite Co-operation Council, we will also endeavor to ensure that the private sector follows the strong example that has now been set by budgetary institutions.

31. We will reform wage-setting mechanisms to ensure that employee compensation evolves in line with the constraints imposed by a fixed exchange rate. The National Tripartite Co-operation Council will establish a Committee to Promote Wage Restraint by end-January 2009 (Structural Benchmark). Its mandate will be to (i) monitor the implementation of measures to reduce nominal wages (and bonuses) in the public and private sectors, and (ii) issue recommendations to ensure that the deterioration in competitiveness is corrected and that compensation evolves in the future in line with the constraints imposed by the fixed exchange rate. The committee will prepare a monthly report that will be discussed by the full National Tripartite Co-operation Council, presented to the Prime Minister and Parliament, and published.

\section{We will support the rebalancing of the economy through vigorous structural}

reforms. To this effect we will form a national committee to examine Latvia's long-term strategic options. In any event, we will press ahead with objectives set out in the National Lisbon Program, including measures to promote the development of new products and technologies, increase labor market flexibility, and facilitate regional mobility, in general aiming for a substantial strengthening of the business environment, thereby also ensuring that 
Latvia's ability to attract inward investment is enhanced. Administrative burdens on the private sector will be reduced significantly, particularly those hampering small and mediumsized enterprises. We will also take a number of measures to promote exports, including streamlining reimbursements of overpaid VAT, and increasing the availability of risk capital and guarantees by launching a holding fund financed by the European Investment Fund (EIF).

\section{IMF ARRANGEMENT}

33. We believe that the policies described in this letter will achieve the goals of our economic program: maintenance of the exchange rate peg; macroeconomic stability; and euro adoption. Nevertheless, we stand ready to take additional measures to keep the program on track if required. We will consult with the IMF on the adoption of these measures, and in advance of revisions to the policies contained in this Letter, in accordance with the IMF's policies on such consultation, and supply such information as the IMF requests on policy implementation and achievement of program objectives.

34. We recognize the importance of completing a safeguards assessment by the first review of the SBA. In this regard, the Bank of Latvia will provide the information required to complete the assessment by the first review and receive a safeguards mission from the IMF as necessary. All long-term funds provided under the program will be disbursed to the government of Latvia and held in an account at the Bank of Latvia.

35. We authorize the IMF to publish this Letter of Intent and its attachments (including the Technical Memorandum of Understanding), and the related staff report.

Sincerely Yours,

Ivars Godmanis /s/

Prime Minister

Atis Slakteris /s/

Ilmārs Rimšēvičs /s/

Minister of Finance

Governor of the Bank of Latvia

Irēna Krūmane /s/

Chairwoman

Financial and Capital Market Commission 
Table 1. Latvia: Prior Actions, Performance Criteria, and Structural Benchmarks for 2008-09

\section{Prior actions}

1. The management of Parex bank to develop a resolution plan considering all options for the bank, and submit it to the FCMC.

Attachment, Para. 12

2. Parliament to adopt a supplementary budget for 2009 with a general government deficit at below 5 percent of GDP.

3. The government will sign a protocol that stipulates a 15 percent reduction in local government employees' compensation.

1. Floors on the net international reserves of the Bank of Latvia

(net of government foreign liabilities resulting from program financing; in million euros)

2. Ceilings on the net domestic assets of the Bank of Latvia.

(inlcuding government foreign liabilities resulting from program financing; in million lats)

3. Floors on the adjusted cash fiscal balance of the general government (in million lats).

4. Ceiling on the general government wage bill (in million lats).

\begin{tabular}{ccccc} 
Performance criteria & \multicolumn{3}{c}{ Indicative targets } \\
Dec-08 & Mar-09 & Jun-09 & Sep-09 & Dec-09 \\
2,103 & 737 & -507 & $-1,128$ & $-1,531$ \\
& & & & \\
951 & 1,434 & 2,501 & 2,656 & 2,928 \\
& & & & \\
-894 & -305 & -649 & -893 & $-1,282$ \\
& \multicolumn{4}{c}{ Indicative targets } \\
1,248 & 214 & 490 & 660 & 884
\end{tabular}

Continuous performance criteria

Non-accumulation of domestic arrears by the general government.

Non-accumulation of external debt payments arrears by the general government.

Structural performance criterion

Submit a second supplementary budget law for 2009 to Parliament to define the allocation of total spending appropriations

among spending agencies and ministries, by end-March 2009.

Attachment, Para. 25

\section{Structural benchmarks}

1. Initiate a focused examination of the banking system by international audit firms, to ensure that banks are solvent

and have sufficient liquidity; by end-March 2009 .

2. Adopt operational guidelines for the provision of emergency liquidity assistance (ELA)

to clarify procedures for inter-agency coordination, cross-border arrangements and the treatment of collateral; by end-December 2008 .

3. Review regulations on emergency liquidity support, and if necessary adopt revised regulations,

with the aim of ensuring they are (i) consistent with international practice and (ii) provide for adequate safeguards by end-January 2009

Attachment, Para. 26

4. Amend the banking laws to allow the FCMC, BoL and the Ministry of Finance to take timely and effective actions

to restore financial stability in systemic crises and enhance the special bank insolvency regime; by end-June 2009.

5. Develop a comprehensive debt restructuring strategy; by end-April 2009

6. Amend the Insolvency Law in order to facilitate orderly and efficient debt restructurings; by end-June 2009.

7. Adopt a decision of the cabinet of ministers to reform controls on budget execution; by end-December 2008.

8. Adopt an amendment on fiscal responsibility to the current Budget and Financial Management Law that will aim to reduce public debt,

set expenditure ceilings, avoid procyclicality in fiscal policy and ultimately allow automatic stabilizers to operate fully; by end-June 2009 .

9. Establish a committee to promote wage restraint; by end-January 2009.

Attachment, Para. 13

Attachment, Para. 14

Attachment, Para. 14

Attachment, Para. 15

Attachment, Para. 16

Attachment, Para. 18

Attachment, Para. 27

Attachment, Para. 28

Attachment, Para. 31 


\section{ATtaChment II. LaTVia: Technical Memorandum OF Understanding (TMU)}

December 17, 2008

1. This Technical Memorandum of Understanding (TMU) defines the variables subject to quantitative targets (performance criteria and indicative targets) established in the letter dated December 17, 2008 from the Prime Minister, the Minister of Finance and the Governor of the Bank of Latvia, and describes the methods to be used in assessing program performance with respect to these targets.

2. For program purposes, all foreign currency-related assets, liabilities, and flows will be evaluated at "program exchange rates" as defined below, with the exception of the government fiscal balances, which will be measured at current exchange rates. The program exchange rates are those that prevailed on November 28, 2008. In particular, the exchange rates for the purposes of the program of the Latvian Lat (LVL) to the euro is set at LVL $0.702804=€ 1$, to the U.S. dollar at LVL $0.544=\$ 1$, and to the Japanese yen at LVL 0.00571 $=1 \mathrm{JPY}$, as shown on the website of the Bank of Latvia (BoL).

\section{A. Floor on Net International Reserves of the BoL}

\begin{tabular}{lc}
\hline & (in million euros) \\
\hline Outstanding stock: & \\
$\quad$ November 30, 2008 & 3,368 \\
& \\
Floors on level of NIR: & 2,103 \\
December 31, 2008 (performance criterion) & 737 \\
March 31, 2009 (performance criterion) & -507 \\
June 30, 2009 (indicative target) & -1128 \\
September 30, 2009 (indicative target) & $-1,531$ \\
December 31, 2009 (indicative target) & \\
\hline
\end{tabular}

3. For the purpose of the program, net international reserves (NIR) of the BoL are defined as the difference between the BoL's foreign reserve assets and the BoL's foreign reserve liabilities, minus Treasury liabilities to the IMF, the European Union and other official creditors participating in the program.

4. Foreign reserve assets of the $\mathrm{BoL}$ are defined as all claims on nonresidents denominated in convertible currencies. They include the BoL's holdings of monetary gold, SDRs, foreign currency cash, foreign currency securities, deposits abroad, participating interests in the European Central Bank and the Bank for International Settlements, and other foreign assets. Excluded from foreign reserve assets are any assets that are frozen, pledged, used as collateral, or otherwise encumbered, except if already included as foreign liabilities, 
precious metals other than gold, assets in nonconvertible currencies, and illiquid assets. As of November 30, 2008, foreign reserve assets thus defined amounted to 3,618 million euro.

5. Foreign reserve liabilities of the BoL are defined as all liabilities to nonresidents, including commitments to sell foreign exchange arising from derivatives (such as futures, forwards, swaps, and options) and banks foreign currency deposits against reserve requirements. Government foreign exchange deposits with the BoL are not treated as a foreign reserve liability. As of November 30, 2008, reserve liabilities thus defined amounted to 250 million euro.

6. As of November 30, 2008 the sum of Treasury liabilities to the IMF, the European Union and other official creditors participating in the program amounted to 0 billion euro.

\section{B. Ceiling on Net Domestic Assets of the BoL}

(in million lats)

Outstanding stock:

November 30, 2008

Ceiling on level of NDA:

December 31, 2008 (performance criterion)

March 31, 2009 (performance criterion)

June 30, 2009 (indicative target)

September 30, 2009 (indicative target)

December 31, 2009 (indicative target)
$-99$

951

1434

2,501

2,656

2,928

7. For the purpose of the program, net domestic assets (NDA) of the BoL are defined as base money minus the net foreign assets (NFA) of the BoL, plus Treasury liabilities to the $\mathrm{IMF}$, the European Union and other official creditors participating in the program, expressed in local currency, at program exchange rates.

8. Base money is defined as currency in circulation (outside banks), vault cash of banks, and required and excess reserve deposits of financial institutions in lats and in foreign currency held at the BoL, or at the BoL accounts abroad (excluding financial sector funds deposited in the BoL's deposit facility and in term deposits in the BoL). As of November 30, 2008, base money thus defined amounted to 2,268 million lats.

9. Net foreign assets of the BoL are defined as the difference between the BoL's foreign reserve assets and the BoL's foreign reserve liabilities as defined in paragraphs 2 and 3 respectively, plus those foreign reserve assets of the BoL that were excluded from the definition in paragraph 2. As of November 30, 2008, net foreign assets of the BoL amounted to 2,367 million lats. 
10. The above ceilings are based on the assumption that all program related financing will be given to the Latvian government and will be deposited in the government's account in the BoL.

11. If the reserve requirement ratio and/or the definition of liabilities subject to reserve requirements is changed during the program period, the BoL will consult with the IMF staff to modify the above limits appropriately.

\section{Adjustor}

12. The NDA ceiling for end-December 2008 will be adjusted downwards by 200 million lats, if the BoL's recent foreign exchange swaps with foreign central banks are not closed by the end of 2008 .

\section{Floor on the Adjusted Cash Fiscal Balance of the General Government}

(in million of lats)

Adjusted cash fiscal balance in 2007

$-362$

Cumulative adjusted cash fiscal balance from January 1, 2008:

December 31, 2008 (performance criterion) $-894$

Cumulative adjusted cash fiscal balance from January 1, 2009:

March 31, 2009 (performance criterion) $\quad-305$

June 30, 2009 (indicative target)

September 30, 2009 (indicative target)

December 31, 2009 (indicative target) $\quad-1,282$

13. The general government includes: (i) the central government, including all ministries, agencies and institutions attached thereto, as defined in the basic budget; (ii) the social security fund (first pillar), as described in the special budget; (iii) the municipalities, regional governments and their special budgets, which are classified as part of general government according to the budget documents and which are included by the BoL in its monthly submissions to the IMF of balance sheets of the central bank and the consolidated accounts of the commercial banks. No off-budgetary funds will be maintained or created. This definition of general government also includes any new funds, or other special budgetary and extrabudgetary programs that may be created during the program period to carry out operations of a fiscal nature as defined in the IMF's Manual on Government Finance Statistics 2001. The authorities will inform IMF staff of the creation of any such new funds or programs immediately. 
14. The adjusted cash fiscal balance of the general government is defined as net government lending/borrowing, in cash and excluding bank restructuring costs (LOI $\uparrow 13$ ), plus EU project grants (reimbursements and advances). This criterion will be monitored and reported based on financing information on a monthly basis, and reconciled with revenue and expenditure reports as soon as those become available, at the latest 30 days after the end of each month.

15. EU financed expenditure will be reported on a monthly basis, distinguishing between subsidies and transfers and capital expenditure, and between central and local government. Some EU financed expenditure may be reallocated from subsidies (excluding social support) to capital expenditure over the course of the fiscal year.

16. For the purpose of the program, the cash fiscal balance of the general government excludes bank restructuring costs, including inter alia: loans to financial institutions and investments in equity of financial institutions (requited recapitalization); unrequited recapitalization; and purchase of troubled assets. However, any financial operation from the general government to support banks, including the emission of guarantees or the provision of liquidities, will be immediately reported to IMF staff.

17. Consistent with the NDA ceilings in section B, the government will deposit all program related financing in its account in the BoL.

\section{Adjustor}

18. The quarterly floor for the adjusted cash fiscal balance of the general government will be adjusted upwards starting in 2009 for interest receipts or capital gains from government deposits or investments in the banking system, including in the BoL, in excess of 15 million lats each quarter.

\section{Ceiling on the General Government Wage Bill}

(in million of lats)

$\begin{array}{lc}\text { Wages and salaries in } 2007 & 1,060 \\ & \\ \text { Wages and salaries (ceiling): } & 1,248 \\ \text { Cumulated from January 1, 2008 } & \\ \text { December 31, 2008 (indicative target) } & \\ & 214 \\ \text { Cumulated from January 1, 2009 } & 490 \\ \text { March 31, 2009 (indicative target) } & 660 \\ \text { June 30, 2009 (indicative target) } & 884 \\ \text { September 30, 2009 (indicative target) } & \\ \text { December 31, 2009 (indicative target) } & \end{array}$


19. The ceiling on the general government wage bill includes general government (as defined above) wages and salaries, including allowances, and bonuses. No in kind benefits will be increased or created during the program period.

\section{E. Continuous Performance Criterion on Non-accumulation of Domestic Arrears by the general government}

20. General government domestic arrears, defined as amounts that have not been paid by the date specified in a contract or within a normal commercial period for similar transactions by the general government, will be kept at zero for the duration of the program. This performance criterion will apply on a continuous basis.

\section{F. Continuous Performance Criterion on Non-accumulation of External Debt Payments Arrears by the General Government}

21. The general government will accumulate no new external debt payments arrears during the program period. For the purposes of this performance criterion, an external debt payment arrear will be defined as a payment due to nonresidents by the general government, which has not been made within seven days after falling due. This performance criterion does not cover trade credits, or nonresident deposits in state-owned banks. This performance criterion will apply on a continuous basis.

22. The stock of external debt payments arrears of the general government will be calculated based on the reported schedule of external payments obligations. Data on external debt payments arrears will be reconciled with the relevant creditors, and any necessary adjustments will be incorporated in these targets as they occur.

\section{G. Monitoring and Reporting Requirements}

23. Performance under the program will be monitored from data supplied to the IMF by the BoL, the Financial and Capital Markets Commission, and the Ministry of Finance as outlined in Table 1. The authorities will transmit promptly to the IMF staff any data revisions. 
Table 1. Republic of Latvia: Data to be Reported to the IMF

Item $\quad$ Periodicity

\section{To be provided by the Ministry of Finance}

Consolidated central (basic and special budgets), local and general government operations based on the IMF fiscal template

Data on EU project grants (reimbursements and advances), capital expenditures and subsidies covered by EU advances or eligible for EU reimbursement on EUsupported projects specifically agreed with the EU Consolidated central and general government bank restructuring operations

Privatization receipts received by the general government budget (in lats and foreign exchange, and payments in governments bonds)

Information on debt stocks and flows, domestic and external (concessional and non concessional), by currency, and guarantees given on new debt, contracted by the (i) consolidated central, local and general governments and (ii) public enterprises Information on new contingent liabilities, domestic and external, of the consolidated central, local and general governments

Data on general government arrears, including to suppliers

Data on operations of extrabudgetary funds

Data on the stock of the general government system

external arrears

\section{To be provided by the Bank of Latvia}

Balance sheet of the BoL (in both program and actual exchange rates)

Consolidated accounts of the commercial banks

Monetary survey

Data on components of the NIR of the BoL (in both

program and actual exchange rates)

Currency operations, including government foreign

receipts and payments and breakdown of interbank market operations by currencies (interventions)

Foreign exchange rate data

Volume of foreign exchange lats trades

Projections for external payments of the banking sector falling due in the next four quarters, interest and amortization (for medium and long-term loans)
Monthly, within four weeks of the end of each month

Monthly, within three weeks of the end of each month

Daily, by end of next working day

Monthly, within four weeks of the end of each month

Monthly, within four weeks of the end of each month

Monthly, within four weeks of the end of each month

Monthly, within four weeks of the end of each month

Monthly, within four weeks of the end of each month Daily, with a seven days lag

Monthly, within three working days of the end of each month

Monthly, within two weeks of the end of each month Monthly, within two weeks of the end of each month Weekly, within one week of the end of each week

Daily, by end of next working day

Daily, by end of next working day

Monthly (weekly for a sample of large banks), within one week of the end of each week

Quarterly, within four weeks of the beginning of the year 
Projections for external payments of the corporate sector falling due in the next four quarters interest and amortization (for medium and long-term loans) The stock of external debt for both public and private sector

The BoL will continue to provide balance of payments data in electronic format.

\section{To be provided by the Financial and Capital}

\section{Markets Commission}

Daily deposit monitoring bank by bank in the agreed format

Daily detailed deposit monitoring in Parex Bank in the agreed format

Banking system monitoring indicators in the agreed format (liquidity, credit quality, summary capital adequacy, simplified balance sheet and income statements)

Detailed capital adequacy reporting in the agreed format Commercial banks' balance sheets (bank-by-bank) Commercial banks' income statements (bank-by bank)
Annually, within three months after the end of the second quarter

Monthly, within four weeks of the end of each month for the public and the banking sector; quarterly, within three months of the end of each quarter for total external debt Monthly, within six weeks of the end of each month

Daily, by end of next working day

Daily, by end of next working day

Monthly, within four weeks of the end of each month

Quarterly, within four weeks of the end of each quarter Quarterly, within four weeks of the end of each quarter Quarterly, within four weeks of the end of each quarter 


\title{
INTERNATIONAL MONETARY FUND
}

\section{Republic of Latvia-Assessment of the Risks to the Fund and the Fund's Liquidity Position}

\author{
Prepared by the Finance and Strategy, Policy, and Review Departments \\ In consultation with other Departments
}

Approved by Andrew Tweedie and Tessa van der Willigen

December 19, 2008

1. This note assesses the risks to the Fund arising from the proposed Stand-By Arrangement (SBA) with Latvia and its effects on the Fund's liquidity, in accordance with the policy on exceptional access. ${ }^{12}$ The authorities are requesting a 27-month SBA with access of SDR 1.522 billion (1,200 percent of quota). ${ }^{3}$ Proposed access is front-loaded, with SDR 535 million (422 percent of quota) available upon approval, and SDR 178 million (141 percent of quota) available in both February and May 2009 (Table 1). The remaining access is phased in six quarterly purchases of SDR 89 million (70 percent of quota), and a final purchase of SDR 94 million (74 percent of quota) scheduled for February 2011.

Table 1. Latvia: Proposed SBA-Access and Phasing

\begin{tabular}{llrrr}
\hline & & \multicolumn{3}{c}{ Purchases } \\
\cline { 3 - 5 } Availability & Date 1/ & & \multicolumn{2}{c}{ Percent of quota } \\
\cline { 3 - 5 } 2008 & December (Approval) & 535.3 & 422.2 & 422.2 \\
2009 & February & 178.4 & 140.7 & 562.9 \\
& May & 178.4 & 140.7 & 703.7 \\
& August & 89.2 & 70.4 & 774.0 \\
\multirow{2}{*}{2010} & November & 89.2 & 70.4 & 844.4 \\
& February & 89.2 & 70.4 & 914.8 \\
& May & 89.2 & 70.4 & 985.1 \\
& August & 89.2 & 70.4 & $1,055.5$ \\
& November & 89.2 & 70.4 & $1,125.9$ \\
& February & 94.0 & 74.2 & $1,200.0$ \\
\hline & Total & $1,521.6$ & $1,200.0$ & $1,200.0$ \\
\hline
\end{tabular}

Source: Finance Department.

1/ Starting from February 2009, purchases will depend on the completion of a review.

\footnotetext{
${ }^{1}$ See The Action Chair's Summing Up of the Review of Access Policy Under the Credit Tranches and the Extended Fund Facility, and Access Policy in Capital Account Crises-Modifications to the Supplemental Reserve Facility and Follow-Up Issues Related to Exceptional Access Policy.

2 The Analysis in this supplement is based on information on Fund arrangements as of end-November 2008.

${ }^{3}$ This supplement uses rounded figures (see the staff report for exact amounts of access and purchases.)
} 


\section{BACKGROUND}

\section{Latvia had an extensive program relationship with the Fund during the first} decade after it became a member in May 1992, but it has not purchased Fund resources since 1994 (Table 2). Purchases from the General Resources Account (GRA) were made under two SBAs in 1992-94, and under the Systemic Transformation Facility (STF) in 1993-94. Subsequently, Latvia had five precautionary SBAs under which no purchases were made. The last of these precautionary arrangements expired in December 2002. Total Fund credit to Latvia peaked at SDR 110 million in 1994 and declined thereafter until full repayment in 2004 (Figure 1).

Table 2. Latvia: IMF Financial Arrangements, Purchases and Repurchases, 1992-2016 (In millions of SDRs)

\begin{tabular}{|c|c|c|c|c|c|c|c|c|c|c|}
\hline Year & & $\begin{array}{l}\text { Type of } \\
\text { Facility }\end{array}$ & $\begin{array}{c}\text { Date of } \\
\text { Arrangement }\end{array}$ & $\begin{array}{l}\text { Date of } \\
\text { Expiration or } \\
\text { Cancellation }\end{array}$ & $\begin{array}{l}\text { Amount } \\
\text { Approved }\end{array}$ & $\begin{array}{l}\text { Amount } \\
\text { Drawn }\end{array}$ & Purchase & & Repurchases & $\begin{array}{c}\text { Fund } \\
\text { Exposure 1/ }\end{array}$ \\
\hline 1992 & & SBA & 14-Sep-1992 & 13-Sep-1993 & 54.9 & 54.9 & 25.2 & & -- & 25.2 \\
\hline 1993 & & SBA/STF 2/ & 15-Dec-1993 & 14-Mar-1995 & 22.9 & 9.2 & 52.6 & $3 /$ & -- & 77.8 \\
\hline 1994 & & & & & & & 32.0 & $3 /$ & -- & 109.8 \\
\hline 1995 & & SBA & 21-Apr-1995 & 20-May-1996 & 27.5 & 0.0 & -- & & 1.9 & 107.9 \\
\hline 1996 & & SBA & 24-May-1996 & 23-Aug-1997 & 30.0 & 0.0 & -- & & 17.5 & 90.4 \\
\hline 1997 & & SBA & 10-Oct-1997 & 9-Apr-1999 & 33.0 & 0.0 & -- & & 26.7 & 63.7 \\
\hline 1998 & & & & & & & -- & & 18.3 & 45.4 \\
\hline 1999 & & SBA & 10-Dec-1999 & 9-Apr-2001 & 33.0 & 0.0 & -- & & 11.1 & 34.3 \\
\hline 2000 & & & & & & & -- & & 7.6 & 26.7 \\
\hline 2001 & & SBA & 20-Apr-2001 & 19-Dec-2002 & 33.0 & 0.0 & -- & & 7.6 & 19.1 \\
\hline 2002 & & & & & & & -- & & 7.6 & 11.4 \\
\hline 2003 & & & & & & & -- & & 7.6 & 3.8 \\
\hline 2004 & & & & & & & -- & & 3.8 & -- \\
\hline$\cdots$ & & & & & & & -- & & -- & -- \\
\hline$\ldots$ & & & & & & & -- & & -- & -- \\
\hline 2008 & 4/ & $S B A$ & 23-Dec-2008 & & $1,521.6$ & & 535.3 & & -- & 535.3 \\
\hline 2009 & 4/ & & & & & & 535.3 & & -- & $1,070.7$ \\
\hline 2010 & $4 /$ & & & & & & 356.9 & & -- & $1,427.6$ \\
\hline 2011 & $4 /$ & & & & & & 94.0 & & -- & $1,521.6$ \\
\hline 2012 & $4 /$ & & & & & & -- & & 390.4 & $1,131.3$ \\
\hline 2013 & $4 /$ & & & & & & -- & & 602.3 & 529.0 \\
\hline 2014 & 4/ & & & & & & -- & & 358.7 & 170.3 \\
\hline 2015 & 4/ & & & & & & -- & & 158.6 & 11.8 \\
\hline 2016 & 4/ & & & & & & -- & & 11.8 & -- \\
\hline
\end{tabular}

Source: Finance Department.

$1 /$ As of end-December, unless otherwise indicated.

2/ The IMF established the Systemic Transformation Facility (STF) as a temporary financing window to provide assistance to member countries facing balance of payments difficulties arising from severe disruptions on their traditional trade and payments arrangements owing to a shift from reliance on trading at non market prices to a multilateral market-based system. The STF was created in April 1993 and allowed to lapse in April 1995.

3/ Includes a drawing under the 1993 STF of SDR 22.9 million.

4/ Figures under the proposed program in italics. Assumes repurchases on an obligations basis. 
Figure 1. Latvia: IMF Credit Outstanding, 1992-2004

(In millions of SDRs)

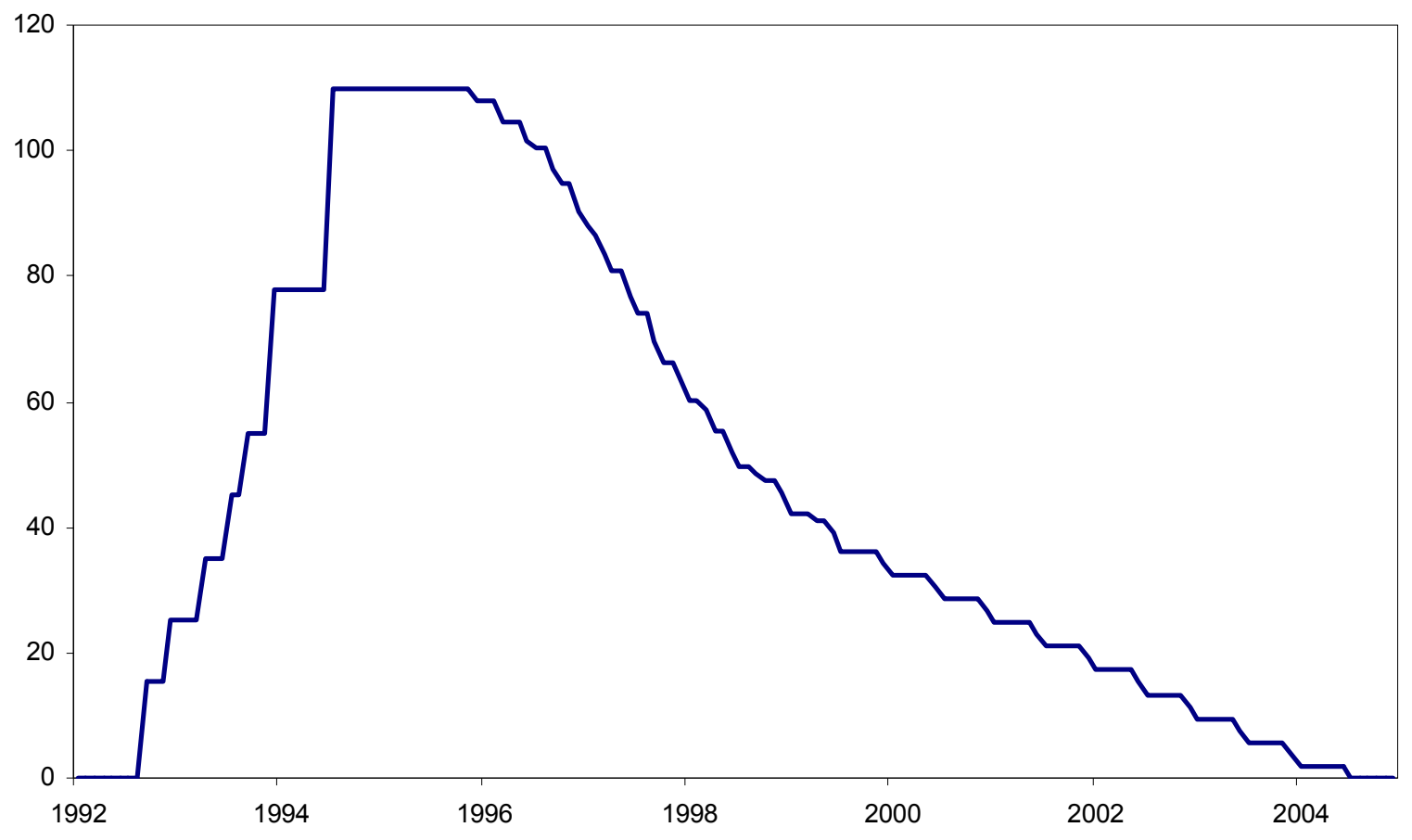

Source: Finance Department

\section{Years of unsustainably high growth stimulated by large capital inflows have} coalesced into a financial and balance of payments crisis. Although the current account deficit is now correcting quickly, external vulnerabilities remain substantial. Gross external debt has risen to 130 percent of GDP, the highest among EU new member states, which is higher than all of the recent exceptional access cases except Iceland (Tables 3 and 4). ${ }^{4}$ The private sector accounts for the bulk of external debt and has net external debt of 70 percent of GDP (Figure 2). The public sector is currently a net external creditor, though there is a risk that it will have to assume private sector liabilities related to the banking sector. A large proportion of the gross external debt is also short-term, which contributes to a projected total financing requirement of 29 percent of GDP in 2009.

\footnotetext{
${ }^{4}$ The exceptional access cases used as comparators in this paper are nine of the ten arrangements approved since the exceptional access procedures were put in place (Argentina, Brazil, Turkey, Uruguay, Georgia, Ukraine, Hungary, Iceland, and Pakistan.) The 2008 extended arrangement for Liberia also involved exceptional access. However, this arrangement was different from other exceptional access cases since, in this case, exceptional access was granted in the context of Liberia's clearance of arrears to the Fund.
} 
Table 3. Latvia: External Debt, 2005-2008

\begin{tabular}{|c|c|c|c|c|c|}
\hline & & 2005 & 2006 & 2007 & $20081 /$ \\
\hline & & \multicolumn{4}{|c|}{ (In millions of Euros) } \\
\hline \multicolumn{2}{|c|}{ Total External Debt } & 12,876 & 18,230 & 26,629 & 28,058 \\
\hline \multirow[t]{3}{*}{ of which: } & Public & 855 & 916 & 1,068 & 2,207 \\
\hline & Private & 12,021 & 17,314 & 25,562 & 25,852 \\
\hline & & \multicolumn{4}{|c|}{ (In percent of GDP) } \\
\hline \multicolumn{2}{|c|}{ Total External Debt } & 100.0 & 114.8 & 134.2 & 129.2 \\
\hline \multirow[t]{2}{*}{ of which: } & Public & 6.6 & 5.8 & 5.4 & 10.2 \\
\hline & Private & 93.3 & 109.0 & 128.8 & 119.0 \\
\hline
\end{tabular}

Sources: Latvian authorities and IMF staff estimates.

1/ Projected to end-2008.

Figure 2. Latvia: External Debt 2008 1/

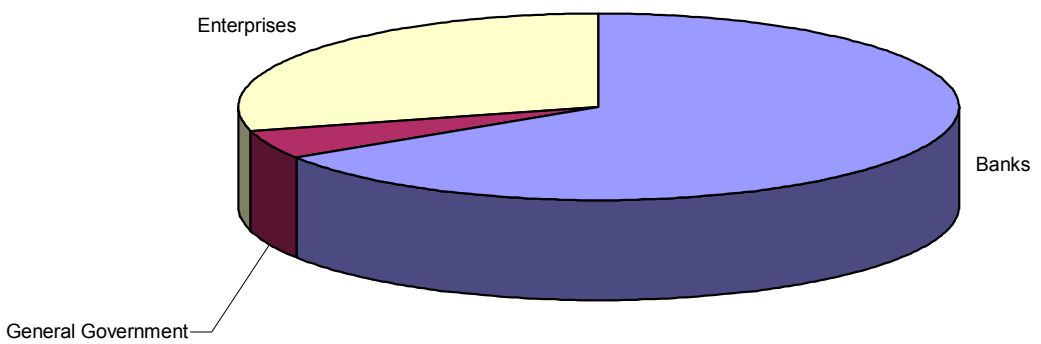

Sources: Latvian authorities and IMF staff estimates. 
Table 4. Debt Ratios in Past Exceptional Access Cases 1/

(In percent of GDP)

\begin{tabular}{lccc}
\hline & Total External Debt & Public External Debt & Debt to IMF \\
\hline A. Earlier arrangements, 2003-05: & & & \\
Argentina (2003) & 129.0 & 82.5 & 12.2 \\
Brazil (2003) & 38.6 & 21.5 & 5.1 \\
Turkey (2005) & 35.0 & 17.8 & 3.0 \\
Uruguay (2005) & 82.0 & 60.8 & 13.8 \\
B. Newly approved arrangements (2008): & & \\
Georgia 2/ & 106.4 & 21.0 & 2.8 \\
Hungary 3/ & 54.3 & 37.6 & 4.2 \\
Ukraine 4/ & 165.0 & 10.4 & 2.5 \\
Iceland 5/ & 31.4 & 99.9 & 5.1 \\
Pakistan 6/ & 29.5 & 3.5 \\
& & & \\
Latvia (2008) 7/ & 129.2 & 10.2 & 2.8 \\
\end{tabular}

Sources: Board documents and IMF staff estimates.

1/ Ratios for the year indicated in parenthesis. Year in parenthesis corresponds to the year of approval of the last IMF arrangement with each country.

2/ End-2008 projection, including PRGF resources.

3/ End-2008 projection, see see Country Report No. 08/361 (11/4/08).

4/ End-2008 projection, see see Country Report No. 08/384 (11/3/08).

5/ End-2008 projection, see ountry Report 08/362 (11/25/08). Estimate excludes US $\$ 84.8$ billion

(505 percent of GDP) of banks' external debt.

4/ End-2008 projection, see see Country Report No. 08/364 (11/20/08).

7/ End-2008 projection, assuming first purchase under proposed arrangement.

\section{THE NEW SBA-RISKS AND IMPACT ON FUND FinANCES}

\section{A. Risks to the Fund}

4. Latvia's proposed access would be high and front-loaded. Latvia's outstanding use of the Fund's GRA resources would reach 422 percent of quota upon approval and would continue to rise to 1200 percent of quota in February 2011. Its outstanding use of Fund resources would exceed the 300 percent cumulative access limit until May 2014. ${ }^{5}$ Relative to quota, the peak exposure to Latvia would exceed all exceptional access cases in recent years aside from Turkey (Figure 3, panel A). Latvia's proposed access level would be the highest among the most recent exceptional access cases, exceeding slightly that of Iceland. Despite Latvia's proposed access being relatively front-loaded, the Fund's peak exposure to Latvia

\footnotetext{
${ }^{5}$ Currency holdings resulting from scheduled purchases under the proposed SBA would be subject to levelbased surcharges from the approval of the arrangement until August 2014 (100 basis points over the basic rate of charge, adjusted for burden sharing, on credit outstanding exceeding 200 percent of quota, and 200 basis points on credit outstanding exceeding 300 percent of quota.)
} 
would be reached somewhat later than in other recent arrangements, given the longer duration of the arrangement (Figure 3, panel B).

\section{If the proposed SBA is drawn in full, Latvia's total outstanding use of Fund} resources will represent 8 percent of GDP by 2011. Access under the proposed SBA is much greater than Latvia's previous exposures to the Fund (Table 2). From its first purchase, Latvia's outstanding use of Fund resources would be 2.8 percent of GDP, higher than those of Pakistan and Ukraine but lower than for Hungary and Iceland (Table 5). Latvia's outstanding use of Fund resources in terms of GDP would reach 7.9 percent by end-2011 (Table 6).

\section{The arrangement will be a significant part of Latvia's high external debt service}

burden if the proposed SBA is fully drawn. By end-2008, Latvia's outstanding use of Fund resources would account for 2.1 percent of external debt, rising to 5.3 percent by end-2011 (Table 6). Given Latvia's already large debt service burden, payments to the Fund would put further strains on its external debt servicing capacity, with projected service under the proposed SBA peaking in 2013 at SDR 635 million, accounting for close to 8 percent of external debt service, over 6 percent of exports of goods and services, and 15 percent of gross reserves. ${ }^{6}$

\footnotetext{
${ }^{6}$ The figures on debt service used in this report correspond to the schedule on an obligations basis, in line with the guidelines stipulated in Review of Fund Facilities-Proposed Decisions and Implementation Guidelines $(11 / 3 / 00)$. Under the obligations schedule, the first repurchase is scheduled to take place in March 2012, 31/4 years after the first purchase under the arrangement. Under the policy on time-based repurchase expectations, there is an expectation that repurchases of holdings resulting from purchases in the credit tranches and the EFF, including under exceptional access, will adhere to the expectations schedule, and an extension from the expectations to the obligations schedule would require a decision by the Executive Board.
} 
Figure 3. Fund Credit Outstanding in the GRA around Peak Borrowing 1/ (in percent of quota)

\section{A. Previous Exceptional Access Cases}

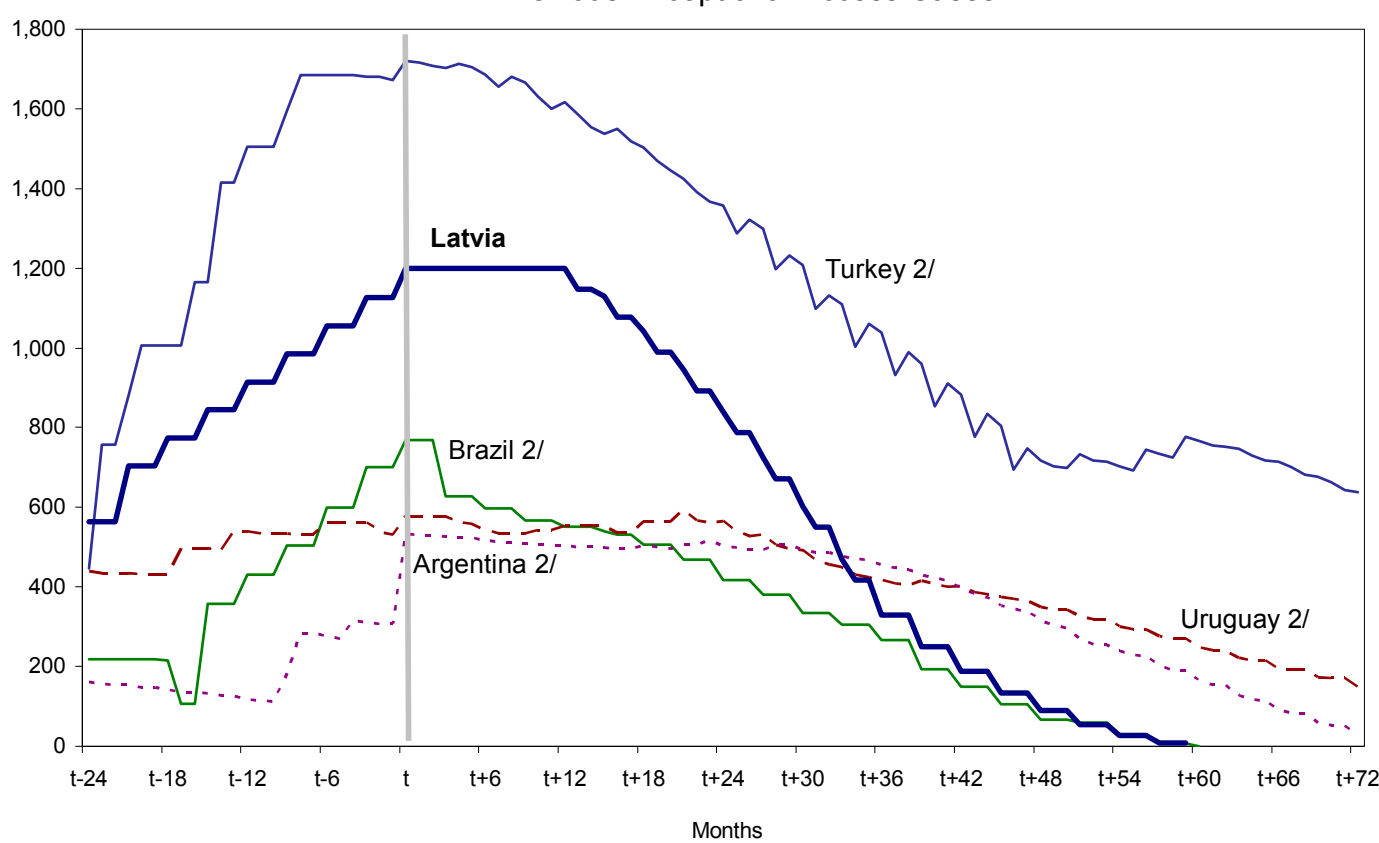

B. Recent Exceptional Access Cases

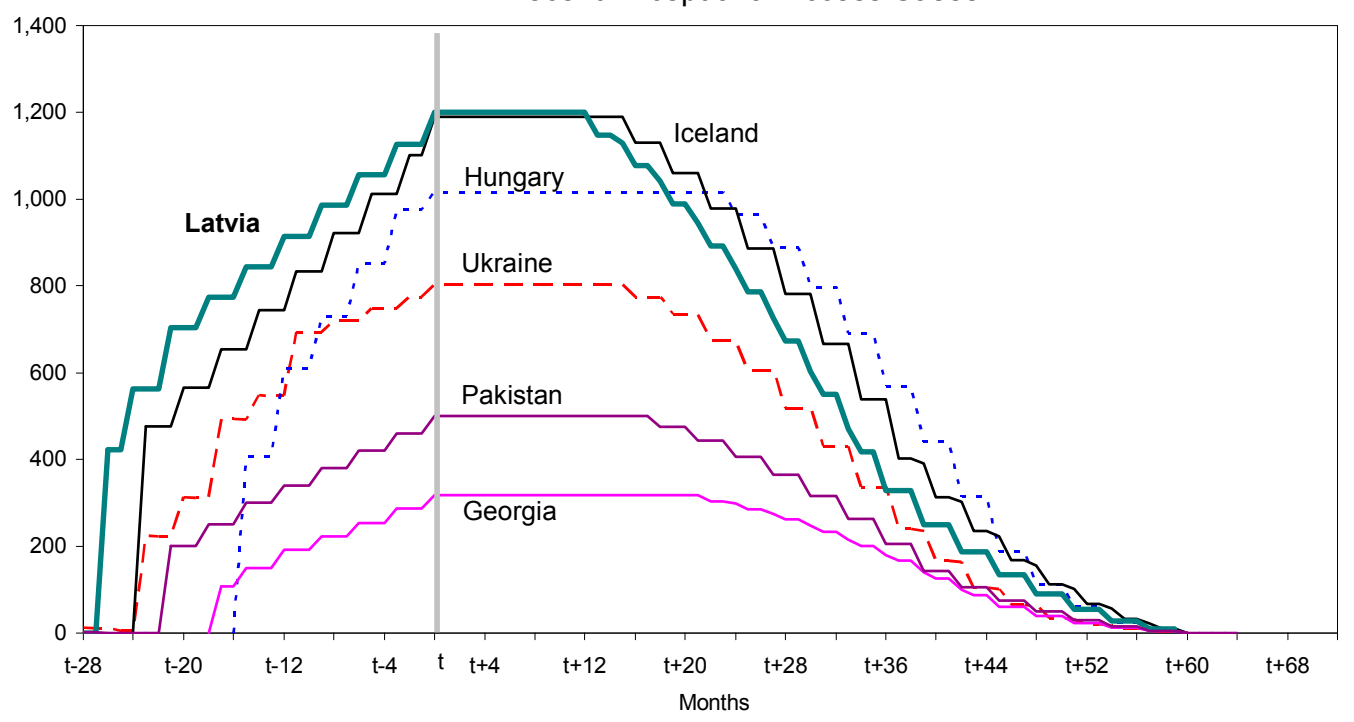

Source: IFS, Finance Department, and IMF staff estimates.

$1 /$ Peak borrowing is defined as the highest level of credit outstanding for a member, in percent of quota. Month $t$ represents the month of the highest historical credit outstanding (in percent of quota). For Argentina, $t$ is September 2001; for Brazil, September 2003; for Turkey, April 2003; and for Uruguay, August 2004. For the countries in Panel $\mathrm{B}$, $\mathrm{t}$ would be reached in February 2010 in the cases of Hungary and Georgia, October 2010 in the cases of Iceland and Ukraine, September 2010 in the case of Pakistan, and February 2011 in the case of Latvia. For comparability, projected repurchases are assumed to be on an obligations basis.

2/ Projected repurchases (on an obligation basis) as of May 2005. Schedules do not show large early repurchases made by Argentina, Brazil, and Uruguay in 2005-06. 
Table 5. Fund GRA Exposures

\begin{tabular}{lccccc}
\hline & & \multicolumn{3}{c}{ In Percent of } \\
\cline { 5 - 6 } & & & & \multicolumn{2}{c}{ Total GRA Credit } \\
\cline { 5 - 6 } & SDR Millions & Quota & GDP 3/ & $\begin{array}{c}\text { As of end-Nov. } \\
\text { 2008 }\end{array}$ & $\begin{array}{c}\text { After approval of } \\
\text { Latvia } \\
\text { arrangement 4/ }\end{array}$ \\
\hline A. Top five borrowers as of end-November 2008 1/ & & & \\
Turkey & $5,673.1$ & 476.2 & 1.1 & 33.1 & 32.1 \\
Hungary & $4,215.0$ & 405.9 & 4.1 & 24.6 & 23.8 \\
Ukraine & $3,068.5$ & 223.7 & 2.5 & 17.9 & 17.3 \\
Pakistan & $2,075.3$ & 200.8 & 2.1 & 12.1 & 11.7 \\
Iceland & 560.0 & 476.2 & 4.7 & 3.3 & 3.2 \\
Latvia 2/ & 535.3 & 422.2 & 2.8 & 0.0 & 3.0 \\
\hline
\end{tabular}

Sources: Finance Department and IMF staff estimates.

1/ Fund credit outstanding as of November 30, 2008.

2/ Fund credit outstanding after the first purchases of the proposed SBA.

3/ Staff projections to end-2008.

4/ Numerator is Fund credit outstanding as of end-November 2008. Denominator is the sum of total Fund GRA credit outstanding as of endNovember 2008 and the first purchases of the proposed arrangement.

\section{B. Impact on Fund Finances}

7. Given the current level of liquidity, the proposed arrangement would have a modest impact on the Fund's liquidity position. The proposed SBA would reduce the one-year forward commitment capacity (FCC) by SDR 1.5 billion, about 1.5 percent of the FCC of SDR 99 billion as of mid-December (Table 6). ${ }^{7}$

\section{Latvia may become the sixth largest exposure in the Fund's lending portfolio.} After the first purchase, Latvia's share of total Fund credit outstanding would be about 3.0 percent, slightly less than that of Iceland which is currently the fifth largest borrower. (Table 5). The share of total credit extended to the top-five users of Fund resources was 91 percent as of end-November 2008, and this measure of portfolio concentration would decline slightly to 88 percent following the first purchase under the proposed arrangement (Table 6).

\footnotetext{
${ }^{7}$ The FCC is the principal measure of Fund liquidity. The (one-year) FCC indicates the amount of quota-based, nonconcessional resources available for new lending over the next 12 months. See The Fund's Liquidity Position-Review and Outlook. Following the creation of the Short-term Liquidity Facility (SLF), the calculation of the FCC will exclude repurchases falling due under the SLF-see A New Facility for Market Access Countries-The Short-Term Liquidity Facility_Proposed Decision.
} 
Table 6. Latvia-Impact on GRA Finances

(in millions of SDRs, at end of period unless otherwise noted)

\begin{tabular}{|c|c|c|c|c|c|c|c|c|c|}
\hline & 2008 & 2009 & 2010 & 2011 & 2012 & 2013 & 2014 & 2015 & 2016 \\
\hline \multicolumn{10}{|l|}{ Exposure } \\
\hline Fund GRA credit outstanding to Latvia $1 /$ & 535.3 & $1,070.7$ & $1,427.6$ & $1,521.6$ & $1,131.3$ & 529.0 & 170.3 & 11.8 & 0.0 \\
\hline Fund GRA credit outstanding to Latvia (percent of quota) 1/ & 422.2 & 844.4 & $1,125.9$ & $1,200.0$ & 892.2 & 417.2 & 134.3 & 9.3 & 0.0 \\
\hline Fund GRA credit outstanding to Latvia (percent of total GRA credit outstanding) 2/ & 3.0 & $\ldots$ & $\ldots$ & $\ldots$ & $\ldots$ & $\ldots$ & $\ldots$ & $\ldots$ & $\ldots$ \\
\hline Fund GRA credit outstanding to five largest debtors (percent of total GRA credit outstanding) 2/ & 88.1 & $\ldots$ & $\ldots$ & $\ldots$ & $\ldots$ & $\ldots$ & $\ldots$ & $\ldots$ & $\ldots$ \\
\hline \multicolumn{10}{|l|}{ Liquidity } \\
\hline One-year Forward Commitment Capacity (FCC) $3 /$ & $99,125.5$ & $\ldots$ & $\ldots$ & $\ldots$ & $\ldots$ & $\ldots$ & $\ldots$ & $\ldots$ & $\ldots$ \\
\hline Latvia's impact on FCC 4/ & $(1,521.6)$ & $\ldots$ & $\ldots$ & $\ldots$ & $\ldots$ & $\ldots$ & $\ldots$ & $\ldots$ & $\ldots$ \\
\hline \multicolumn{10}{|l|}{ Prudential measures } \\
\hline Fund GRA credit outstanding to Latvia (percent of current precautionary balances) $5 /$ & 7.7 & $\ldots$ & $\ldots$ & $\ldots$ & $\ldots$ & $\ldots$ & $\ldots$ & $\ldots$ & $\ldots$ \\
\hline \multicolumn{10}{|l|}{ Debt and Debt Service Ratios 6/ } \\
\hline Latvia's GRA credit outstanding (percent of total external debt) & 2.1 & 4.0 & 5.3 & 5.3 & 4.0 & 1.9 & 0.6 & 0.0 & $\ldots$ \\
\hline Latvia's GRA credit outstanding (percent of GDP) & 2.8 & 5.6 & 7.5 & 7.9 & 5.8 & 2.6 & 0.8 & 0.1 & $\ldots$ \\
\hline Latvia's GRA credit outstanding (percent of gross international reserves) & 16.1 & 35.4 & 33.8 & 31.4 & 23.4 & 13.0 & 3.6 & 0.2 & $\ldots$ \\
\hline Latvia's GRA debt service to the Fund (percent of exports of goods and services) & 0.0 & 0.3 & 0.5 & 0.6 & 4.6 & 6.2 & 3.3 & 1.4 & 0.1 \\
\hline Latvia's GRA debt service to the Fund (percent of total external debt service) & 0.1 & 0.8 & 1.4 & 1.1 & 6.7 & 7.7 & 4.6 & 2.9 & 0.2 \\
\hline \multicolumn{10}{|l|}{ Memorandum items } \\
\hline Fund's precautionary balances $5 /$ & 6,938.6 & $\ldots$ & $\ldots$ & $\ldots$ & $\ldots$ & $\ldots$ & $\ldots$ & $\ldots$ & $\ldots$ \\
\hline Fund's residual burden sharing capacity $7 /$ & 50.0 & $\ldots$ & $\ldots$ & $\ldots$ & $\ldots$ & $\ldots$ & $\ldots$ & $\ldots$ & $\ldots$ \\
\hline Projected payment of charges to the Fund on GRA credit outstanding & 2.7 & 24.8 & 43.2 & 53.9 & 51.0 & 32.5 & 10.2 & 2.1 & 0.1 \\
\hline Projected debt service payments to the Fund on GRA credit outstanding & 2.7 & 24.8 & 43.2 & 53.9 & 441.4 & 634.7 & 368.9 & 160.7 & 11.9 \\
\hline
\end{tabular}

Sources: Latvian authorities, Finance Department, World Economic Outlook, and IMF staff estimates.

1/ Repurchases follow the obligations schedule.

/ Reflects Fund credit outstanding as of November 30, 2008, plus first purchase by Latvia.

3/ As of December 15, 2008. The Forward Commitment Capacity is a measure of the resources available for new financial commitments in the coming year, equal to usable resources plus repurchases

one-year forward minus the prudential balance.

4/ A single country's negative impact on the FCC is defined as the country's sum of Fund credit and undrawn commitments minus repurchases one-year forward.

$5 /$ As of end-April 2008

6/ Staff projections for total external debt, GDP, gross international reserves, and exports of goods and services, as used in the staff report that requests the proposed SBA.

7/ Estimated based on end-November data. Burden-sharing capacity is calculated based on the floor for remuneration at 85 percent of the SDR interest rate. Residual burden-sharing capacity is equal to the total

burden-sharing capacity minus the portion being utilized to offset deferred charges and takes into account the loss in capacity due to nonpayment of burden sharing adjustments by members in arrears. 


\section{Potential Fund exposure to Latvia would be a modest share of the Fund's} precautionary balances. After the first purchase, Fund credit to Latvia would be equivalent to 7.7 percent of the Fund's precautionary balances as of end-April 2008 (Table 6), and this exposure would rise to about 22 percent of current precautionary balances if the proposed SBA is fully drawn.

\section{Nonetheless, if Latvia were to incur arrears on the charges accruing on its GRA} obligations, the Fund's available burden-sharing capacity could be significantly reduced. ${ }^{8}$ Charges on Latvia's GRA obligations are projected at SDR 25 million in 2009 and at SDR 43 million in 2010, compared with the Fund's residual burden-sharing capacity of SDR 50 million as of end-November 2008 (Table 6). However, the potential impact on the burden sharing capacity would decline if the Fund's loan portfolio expands due to purchases made under other recently agreed arrangements or new lending.

\section{AsSessment}

\section{The proposed arrangement with Latvia entails significant financial risks to the} Fund. The proposed level of access is large in terms of most relevant metrics, including the size of Latvia's economy and its debt servicing capacity and is well above previous Fund exposure to Latvia. The relatively small size of the loan (in SDR terms) in relation to the Fund's finances helps contain the risks to the Fund.

\section{High external debt and centering the program on maintaining the current} exchange rate peg entail considerable risks that may adversely affect Latvia's capacity to repay the Fund. Experience from other currency board and fixed exchange rate cases indicates that correcting a large currency misalignment without nominal depreciation is very difficult. Maintaining support for the peg requires prolonged commitment to fiscal consolidation and sustained wage and fiscal discipline by both the private and public sectors. A high level of external financial support is required, especially as Latvia may not be able to reply upon a supportive external environment. Effective mechanisms to restructure private debt will be important to mitigate risks to the program, and regaining access to international capital markets will depend to a large extent on the normalization of those markets. In these circumstances, inadequate program implementation, persistent financial sector instability due to domestic or external factors, and weak structural reforms that fail to improve competitiveness present major downside risks to Latvia's external position and capacity to repay the Fund.

\footnotetext{
${ }^{8}$ Under the burden-sharing mechanism, the financial consequences for the Fund arising from overdue financial obligations are shared between creditors and debtors through a decrease in the rate of remuneration and an increase in the rate of charge, respectively. The Executive Board has set a floor for remuneration at 85 percent of the SDR interest rate. The mechanism is used to compensate the Fund for a loss in income when debtors do not pay charge, and can also be used to accumulate precautionary balances in the special contingent account (SCA), but the
} 
adjustment for the SCA-a was suspended, effective November 1, 2006, by the Executive Board (Decision No. 13858(07/1), adopted January 2, 2007.)

\section{Exceptionally strong domestic policy implementation will be required for the} authorities' strategy to work and to thereby mitigate risks to the Fund. A sustained and forceful implementation of the program, and a prompt response to changes in underlying conditions and deviations from program assumptions, are essential to safeguard Fund resources. Latvia's track-record of successful adjustment in the face of earlier severe shocks, together with the high level of support in Latvia and in the region for the program strategy, provides some confidence that the ambitious policy package will be delivered. 
Press Release No. 08/345

FOR IMMEDIATE RELEASE

December 23, 2008
International Monetary Fund

Washington, D.C. 20431 USA

\section{IMF Executive Board Approves $€ 1.68$ Billion (US\$2.35 Billion) Stand-By Arrangement for Latvia}

The Executive Board of the International Monetary Fund (IMF) today approved a 27-month SDR 1.52 billion (about $€ 1.68$ billion, or US $\$ 2.35$ billion) Stand-By Arrangement for Latvia to support the country's program to restore confidence and stabilize the economy. The approval makes SDR 535.3 million (about $€ 591.5$ million, or US\$826.3 million) immediately available and the remainder in nine installments subject to quarterly reviews. The Stand-By Arrangement entails exceptional access to IMF resources, amounting to about 1,200 percent of Latvia's quota, and was approved under the Fund's fast-track Emergency Financing Mechanism procedures.

The program is centered on maintaining Latvia's exchange rate peg while recognizing that this calls for exceptionally strong domestic policies and substantial international financial assistance. Key elements include:

- $\quad$ immediate measures to stem the loss of bank deposits and international reserves;

- $\quad$ steps to restore confidence in the banking system in the medium-term and to support private debt restructuring;

- fiscal measures to limit the substantial widening in the budget deficit, and prepare for early fulfillment of the Maastricht criteria; and

- incomes policies and structural reforms that will rebuild competitiveness under the fixed exchange rate regime.

The program is part of a coordinated international effort. The European Commission has participated fully in the preparation of the program, along with representatives from the ECB (in line with Latvia's ERM2 membership), Sweden and other Nordic countries. With substantial international support, these policies should allow the economy eventually to emerge from a period of slow growth, with fewer strains on corporate and household balance sheets. 
The Fund's Stand-By Arrangement will fill just over 20 percent of the country's 2009-2011 net financing gap. The remainder will be met by the European Union, the European Bank for Reconstruction and Development, the World Bank and other bilateral creditors. As part of the program, foreign parent banks operating in Latvia have affirmed their commitment to provide their subsidiaries with adequate financing.

Following the Executive Board discussion on Latvia, Mr. Dominique Strauss-Kahn, Managing Director and Chairman, said:

"Latvia faces severe economic challenges. Pressures on liquidity and on international reserves are intense, in part caused by the global financial crisis. These pressures have come at a time of growing concern over the sustainability of Latvia's external debt and increasing vulnerabilities associated with the unsustainable credit and growth boom that followed Latvia's accession to the EU. Very high wage growth in recent years, far outstripping productivity gains, have severely undermined Latvia's competitiveness and contributed to large external imbalances.

"The Latvian authorities have developed a program with the exceptionally strong policies needed to address these challenges. Their program is centered on their determination to maintain the current exchange rate peg in order to lay the groundwork for Latvia's entry into the euro area as soon as possible. For this reason, and given the need to improve competitiveness, a lengthy period of price compression, including wage reductions, will be unavoidable. A deep recession and a drawn-out recovery appear inevitable.

"Sustaining the government's large fiscal adjustment will be critical to the success of the program. Given the government's difficulties in borrowing and the likely additional budgetary burden associated with the costs of bank restructuring, measures to contain the budget deficit are unavoidable. Sizable expenditure cuts will be a central part of the fiscal adjustment. Spending on public investment will be maintained, and social spending protected.

"Financial sector reform to strengthen the banking system will also be key. The government's actions to take control and install new management in a major domestic bank are an essential step for stabilization. For the banking sector in general, enhancing the market regulator's ability to monitor the financial system, and clarifying procedures for providing emergency liquidity assistance, will help promote financial stability.

“The Latvian authorities' program is an appropriately ambitious response in the current circumstances. Determined implementation of this program - supported by the 27-month Stand-By Arrangement under the IMF's exceptional access policy and the very substantial 
financial assistance expected from Latvia's European Union, Nordic and other international partners - will help address Latvia's immediate balance of payments needs. For the future, the program should contain and reverse the increase of external debt, improve competitiveness and return Latvia to a sustainable growth path," Mr. Strauss-Kahn said. 
ANNEX

\section{Recent Economic Developments}

The current global financial crisis has brought Latvia's vulnerabilities to a head. Years of unsustainably high growth and large current account deficits have coalesced into a financial and balance of payments crisis.

Since end-August, private sector deposits have fallen by 10 percent, led by a run on Parex Bank (the second largest bank, and largest domestically owned) which encountered severe liquidity problems after it lost more than a quarter of its deposits. Attempts by the government to negotiate a partial take over of this bank, while allowing the main shareholders to retain significant influence, failed to restore confidence. From end-August to end-November, official reserves fell by almost 20 percent to $€ 3.4$ billion, one third of shortterm external debt and just over 100 percent of base money (from 127 percent in September), as the central bank sold foreign currency to defend the peg.

Despite this substantial intervention, since early October the exchange rate has remained at its upper (depreciated) band, while interbank spreads have spiked. Concerns over the financial system and external debt sustainability increased, and the exchange rate peg came under threat.

\section{Program Summary}

The authorities' program aims to stem the current liquidity crisis and then ensure long-term external stability, while maintaining the exchange rate peg:

The immediate three objectives of the program are to stabilize the financial sector, restore depositor confidence, and to avoid the disorderly adjustment that would follow if the exchange rate peg were abandoned.

To maintain the peg, the program includes measures that ring fence and resolve the immediate problems in Parex Bank, to prevent contamination to the rest of the system. It also draws on substantial outside international financial assistance to meet the demand for foreign exchange.

For the medium-term, the program includes measures to promote economic adjustment and strengthen the peg. The program includes measures to restore confidence in the broader financial system, to halt the drain of external liquidity. Substantial fiscal policy tightening will reduce financing needs, foster real depreciation, and make room for potentially large contingent financial sector liabilities. The program's aim is to meet the Maastricht deficit 
criteria to facilitate adoption of the euro. This exit strategy should help prevent a recurrence of the current difficulties.

The program includes strong incomes policies to reduce inflation and improve competitiveness, and structural policies that should boost productivity growth and help generate the much-needed shift from non-tradables to tradables production. Private sector debt restructuring will also likely be needed.

The IMF also supports the protection of social spending embedded in the program. Latvia's social spending will increase under the program from 21 to 25 percent of the budget, or by $1 \frac{1}{2}$ percent of GDP between 2008 and 2009, to bring it closer with EU and OECD averages. Additional measures to improve the targeting of the social benefits system should be included in the second supplementary budget for 2009 .

The unequivocal commitment of the authorities, and of the other stakeholders to the exchange rate peg has determined their choice of program strategy. Though this commitment augurs well for program ownership, the authorities also recognize that their choice brings difficult consequences, including the need for fiscal tightening and the possibility that recession could be protracted.

Latvia joined the IMF on May 19, 1992; its quota is SDR 126.80 million (about $€ 140.1$ million, or US\$195.7 million), and has no outstanding use of IMF credits. 
Republic of Latvia: Selected Economic Indicators

\begin{tabular}{|c|c|c|c|c|c|}
\hline & 2005 & 2006 & 2007 & 2008 & 2009 \\
\hline \multicolumn{6}{|c|}{ (Annual percent change, unless otherwise stated) } \\
\hline \multicolumn{6}{|l|}{ Real Economy } \\
\hline $\begin{array}{l}\text { Real GDP } \\
\text { Unemployment rate (in percent, }\end{array}$ & 10.6 & 12.2 & 10.3 & -2.0 & -5.0 \\
\hline period average) & 8.7 & 6.8 & 6.2 & 6.7 & 9.0 \\
\hline HICP (Period average) & 6.9 & 6.6 & 10.1 & 15.5 & 5.9 \\
\hline HICP (end of period) & 7.1 & 6.8 & 14.0 & 11.9 & 3.3 \\
\hline \multicolumn{6}{|l|}{$\begin{array}{l}\text { Public Finance } \\
\text { General government balance (in }\end{array}$} \\
\hline $\begin{array}{l}\text { percent of GDP) } \\
\text { General government debt (in }\end{array}$ & -1.1 & -0.9 & 0.7 & -3.0 & -4.9 \\
\hline percent of GDP) & 11.6 & 9.9 & 8.3 & 14.3 & 33.7 \\
\hline \multicolumn{6}{|l|}{ Money and credit } \\
\hline Reserve money & 41.1 & 66.5 & 9.9 & 1.0 & -28.1 \\
\hline Broad money & 38.9 & 37.4 & 12.6 & 0.8 & -3.0 \\
\hline Domestic credit (non-government) & 64.3 & 58.4 & 34.2 & 13.0 & -0.5 \\
\hline \multicolumn{6}{|l|}{ Balance of payments } \\
\hline $\begin{array}{l}\text { Goods and non-factor services } \\
\text { balance (in percent of GDP) } \\
\text { Current account balance (in }\end{array}$ & -15.2 & -22.2 & -21.8 & -13.9 & -7.3 \\
\hline percent of GDP) & -12.5 & -22.5 & -23.8 & -14.8 & -7.3 \\
\hline $\begin{array}{l}\text { International reserves } \\
\text { (in months of imports) }\end{array}$ & 2.3 & 3.2 & 3.7 & 4.0 & 3.8 \\
\hline \multicolumn{6}{|l|}{ Exchange rate } \\
\hline Exchange rate regime & $\leftarrow \mathrm{Pe}$ & Euro - & & & \\
\hline $\begin{array}{l}\text { Exchange rate (lats per US\$; } \\
\text { period average) }\end{array}$ & 0.565 & 0.560 & 0.514 & 0.477 & 0.525 \\
\hline $\begin{array}{l}\text { Real effective exchange rate } \\
(2000=100) 2 /\end{array}$ & 90.1 & 92.6 & 100.1 & 105.3 & $\ldots$ \\
\hline
\end{tabular}

\section{Quota at the Fund}




\section{Statement by Jens Henriksson, Executive Director for the Republic of Latvia and Martins Bitans, Advisor to the Executive Director December 23, 2008}

\section{Recent economic developments and outlook}

Over the last few years, Latvia has enjoyed a rapid economic expansion that was accompanied by significant foreign capital inflows. Years of strong growth led to considerable improvements in living standards and the economy's supply capacity. However, they have also been accompanied by an excessive expansion of domestic demand and rising vulnerabilities, as evidenced by inflation rates well above 15 percent, and current account deficits in excess of 20 percent of GDP in both 2006 and 2007.

The authorities have responded to the rising overheating pressures by adopting an antiinflation plan in the early 2007 . With this plan, the taxation of real estate activity was broadened and new regulations compelled banks to be more circumspect in lending decisions. The fiscal policy was also strengthened considerably in 2007, with the government's budget recording a surplus for the first time in recent years

As a result, lending growth has been decelerating since mid-2007. Moreover, the slowing down of domestic demand has resulted in a sizable improvement of current account deficit and falling inflation. However, the recent international financial market turmoil has magnified the vulnerabilities of the Latvian economy, prompting the need for an accelerated adjustment path and further strengthening of domestic policies.

The largest domestically-owned commercial bank, Parex Bank, has been hit by the loss of confidence and has suffered significant outflows of deposits since September. Amid rising risks of deterioration of confidence that might have serious systemic implications and result into negative regional spillovers, the government decided to take over the institution. However, also other domestic banks and companies have found it increasingly difficult to rollover their international liabilities.

The current financial turmoil has also led to a significant downward revision of the mediumterm growth projections, with significant adverse fiscal implications over the next years. Thus, a significant financing requirement has emerged in the short term, at a time when international capital markets have dramatically scaled back the supply of available external financing.

In response, the Government and the Bank of Latvia, in close cooperation with the Fund's staff, representatives from the EC other institutions and neighboring countries have developed a comprehensive strategy to counter financing pressures in the near term, and put the economy on a sustainable footing in the long term. 


\section{Main elements of the program}

The authorities firmly believe that the existing exchange rate strategy with fixed narrow band should be the centerpiece of an economic stabilization package that would lay the groundwork for the authorities' ultimate economic policy goal of entry into the euro area as soon as possible. The authorities are convinced that the medium-term fiscal consolidation, tight wage policy and confidence building for financial sector policies, backed by complementary strategies in areas such as structural reform and debt restructuring, will underpin competitiveness and restore economic stability.

An immediate and sustained fiscal consolidation will send a strong signal of the authorities' commitment to restore stability and prepare for the euro adoption. Their strategy is anchored in a medium-term fiscal framework that will lower the deficit to the Maastricht level of 3 percent of GDP by 2011. This will require a strong upfront structural adjustment and measures both to cut budget expenditure and to increase the budget revenue base.

The authorities have already passed a parliamentary decision to adopt a supplementary budget for 2009 that takes into account the recent deterioration in the economic outlook and will cap next year's general government fiscal deficit at below 5 percent of GDP. This will imply an adjustment of around 7 percentage points of GDP compared with the budget passed in November. And, while the envisaged fiscal adjustment is indeed remarkable, the authorities aim at preserving social safety nets for the poor, while at the same time maintaining the investment spending so as not to impair the country's long-term growth prospects.

In addition, further comprehensive structural reforms will be implemented to achieve a sustainable fiscal position over the next years. The authorities will seek assistance from the Fund, EU and bilateral donors to strengthen public financial management with the ultimate goal to bring Latvia's fiscal policy on a permanent sustainable footing by incorporating prudent and responsible fiscal rules into the national legislation.

Regarding income policies, authorities are strongly committed to wage restraint, which they see as the most effective instrument for restoring competitiveness and correcting external vulnerabilities. Authorities clearly recognize that wages grew too rapidly during the past boom and they intend to cut average compensation, including wages and bonuses, in the entire public sector by 15 percent in 2009, with further reductions in 2010-2011.

In addition, authorities will reform wage-setting mechanisms to ensure that employee compensation evolves in line with the constraints posed by a fixed exchange rate. A Committee to Promote Wage Restraint comprising a wide range of representatives from public and private sector will be set up and will have a mandate to monitor the implementation of measures to reduce wages in the public and private sectors, and issue recommendations to ensure that the deterioration in competitiveness is corrected and that 
compensation evolves in the future in line with the constraints imposed by the fixed exchange rate.

Regarding financial sector policies, partially taking over and taking control of the Parex Bank represents the first steps towards effectively resolving the bank. The authorities have already installed a credible and competent new management, and suspended the previous owners from any executive role. The authorities aim at obtaining full ownership of the bank. Against this background, the Bank has been instructed to issue an offer to all minority shareholders in order to launch the process of buying back minority shareholders' shares. The government has also requested the new management by January 15, 2009 to select a lead advisor with an aim of attracting a strategic investor for the bank.

To further restore confidence to the banking system, the authorities will develop a comprehensive bank resolution strategy and undertake a focused examination of the banking system. On the basis of this analysis, viable banks that need capital increases will be required to seek private restructuring via outside investors or mergers, or capital support from parent banks.

The authorities will also strengthen our crisis management capacity and amend laws to allow the FCMC, BoL and the Ministry of Finance to take timely and effective actions to restore financial stability in systemic crises and to enhance the special bank insolvency regime. The support from the international community will allow the authorities to provide emergency liquidity assistance (ELA) to solvent banks, while at the same time respecting a fair and equitable treatment of depositors and creditors (both resident and non-resident) in the Latvian banking system.

The authorities recognize the need for a comprehensive strategy to ensure sustainability of the private-sector's domestic and external debt burden. Capital injections including from foreign parent banks, alongside other measures, will play a prominent role to maintain the solvency of the Latvian banking system. In addition, the authorities plan to amend the Insolvency Law in order to facilitate orderly and efficient debt restructurings.

In the area of structural reforms, the authorities will support the rebalancing of the economy through vigorous structural measures. To this end they will form a national committee to examine Latvia's long-term strategic options and will press ahead with objectives set out in the National Lisbon Program. The authorities have also approached the World Bank to seek technical assistance on the comprehensive reforms of education, civil service, state administration and the healthcare systems.

The authorities strongly believe that the policies described above will achieve the goals of their economic program: maintenance of the exchange rate peg; macroeconomic stability; and euro adoption. The authorities acknowledge that their goals and the program designed to achieve those goals are ambitious and challenging. At the same time, the fast and decisive 
steps made so far by the authorities demonstrate their strong commitment to the agreed policy package. Moreover, the authorities stand ready to take additional measures to keep the program on track, if necessary.

Against this background, we ask the Board to support the program and help to put the Latvian economy and the financial system back on a sustainable growth path. 